The Georges Bank Mohitoring Pregiam 1284: Andelysis of Trace Metals in Bottom Sediments During the Sec-ha rear of Monitoring
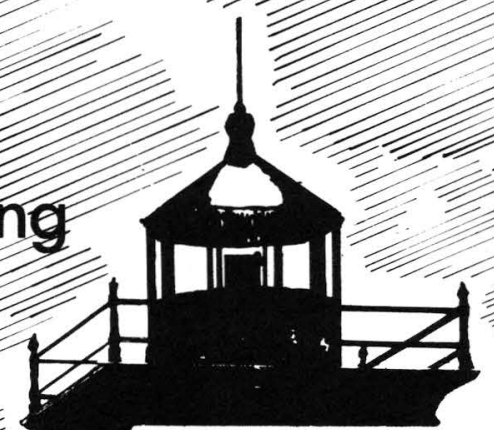

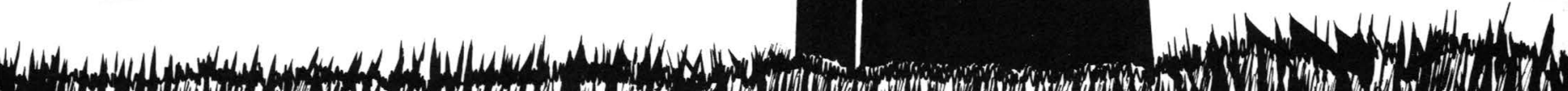
(It)
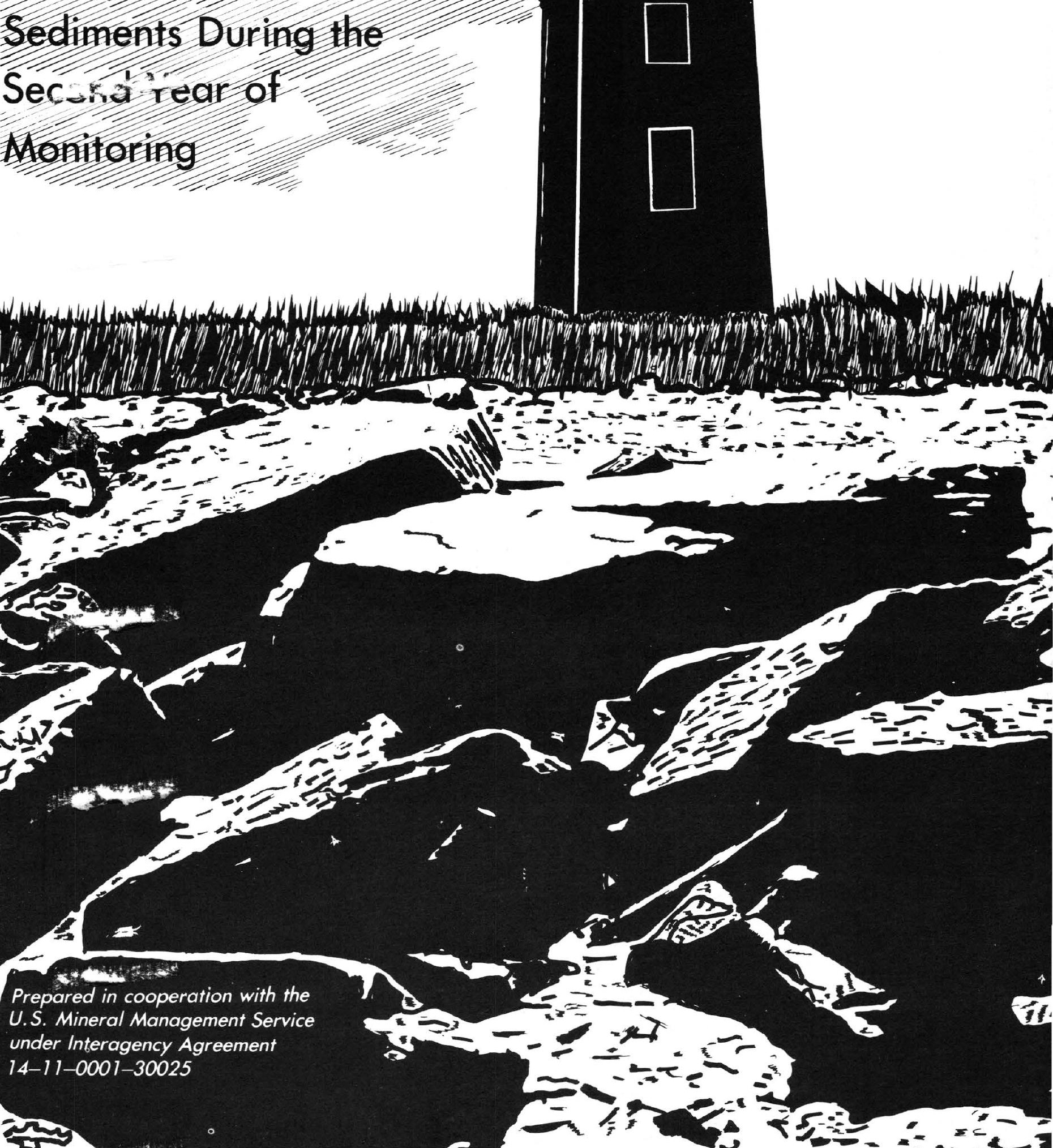


\section{The Georges Bank Monitoring Program 1984: Analysis of Trace Metals in Bottom Sediments During the Second Year of Monitoring}

By M. H. Bothner, R. R. Rendigs, Esma Campbell, M. W. Doughten, C. M. Parmenter, M. J. Pickering, R. G. Johnson, and J. R. Gillison

U.S. GEOLOGICAL SURVEY CIRCULAR 936 Prepared in cooperation with the U.S. Mineral Management Service under Interagency Agreement 14-11-0001-30025 


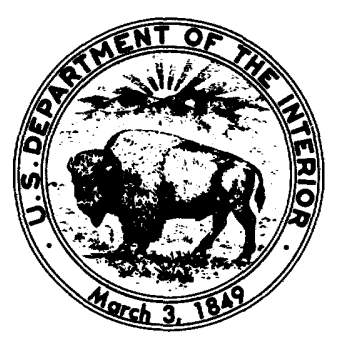

\section{U.S. Geological Survey}

Dallas L. Peck, Director

Use of brand names in this report is for descriptive purposes only

and does not constitute endorsement by the U.S. Geological Survey.

\section{Library of Congress Cataloging in Publication Data}

Main entry under title:

The Georges Bank monitoring program, 1984.

(Geological Survey circular ; 936)

Bibliography: p.

Supt. of Docs. no.: I 19.4/2:936

1. Marine pollution-Georges Bank. 2. Barite-Georges Bank. 3. Metals-Environmental aspects-Georges Bank. I. Bothner, Michael H. II. Series.

QE75.C5 no. $936 \quad 557.3 s \quad[363.7 ' 394] \quad 84-600190$ [GC1211] 


\section{CONTENTS}

Abstract

Introduction

Field sampling and sample preparation

Grain-size analysis techniques

Trace-metal analysis procedures

Preparation of stock solution A

Preparation of stock solution B

Barium

Aluminum, iron, chromium, nickel, and vanadium

Lead, copper, and cadmium

Manganese and zinc

Mercury

Additional methods

Analytical accuracy and precision

Results and discussion

Sediment texture

Trace metals in bulk sediments

Trace metals in the fine fraction of sediment

Trace metals in different size fractions of sediment

Trace-metal concentrations of sediment-trap samples

Trace-metal variations with depth in sediment

Barium inventory and decrease at block 312

Summary of important findings

References cited

Appendix tables

\section{ILLUSTRATIONS}

Figure 1. Map and diagram showing regional sampling stations and site-specific sampling stations around regional station 5

2-18. Graphs showing:

2. Mean grain size of samples collected during years 1 and 2

3. Percent silt plus clay in samples collected at each regional station during years 1 and 2

4. Concentrations of barium in bulk sediment at upstream control stations on different sampling occasions

5. Concentrations of barium and chromium in bulk sediment on different sampling occasions near the drill site at block 410

6. Concentrations of barium and chromium in bulk sediment on different sampling occasions near the drill site at block 312

7. Concentrations of barium and chromium in the fine fraction on different sampling occasions near the drill site at block 410

8. Concentrations of barium and chromium in the fine fraction on different sampling occasions near the drill site at block 312 .

9. Concentrations of barium in the fine fraction on different sampling occasions at stations 8 and $12 \ldots \ldots$

10. Weight percent of sediment in different size fractions of bottom sediment collected on cruise 4 at three locations on Georges Bank

11. Concentrations of barium in different size fractions of bottom sediments collected on cruise 4 at three different locations on Georges Bank

12. Relative amount of total barium in different size fractions of bottom sediments collected on cruise 4 at three different locations on Georges Bank 
Figure 13. Concentrations of aluminum, lead, and copper in different size fractions of bottom sediments collected on cruise 4 at three different locations on Georges Bank

14. Distribution of percent silt plus clay and distribution of barium with sediment depth .............................

15. Distribution of barium in the fine fraction of sediment with sediment depth

16. Net increase in the concentration of barium in bulk sediments during the drilling period at block 312 .

17. Increase in a verage barium concentration of bulk sediment at different radial distances from the rig site in block 312 between the first and fifth monitoring cruises crease of the barite inventory at block 312 with time relative to the amount present at the time of

18. Decrease of the barite inventory at block 312 with
cruise 5,4 weeks after drilling was completed

\section{TABLES}

Table 1. Summary of analytical conditions

2. Mercury concentration of replicate samples dried at different temperatures to evaluate loss of mercury on drying

3. Analysis of sediment standard and replicate sediment samples

4. Chemical analyses of sediment-trap samples collected before and after drilling began

5. Chemical analyses of core samples and grab samples subsectioned into sequential depth intervals 


\title{
The Georges Bank Monitoring Program 1984: Analysis of Trace Metals in Bottom Sediments During the Second Year of Monitoring
}

\author{
By M. H. Bothner, R. R. Rendigs, Esma Campbell, M. W. Doughten, \\ C. M. Parmenter, M. J. Pickering, R. G. Johnson, and J. R. Gillison
}

\begin{abstract}
Of the 12 elements analyzed in bulk (undifferentiated) sediments collected adjacent to drilling rigs on Georges Bank, only barium was found to increase in concentration during the drilling period (July 1981 until September 1982). The maximum postdrilling concentration of barium (a major element in drilling mud) reached $172 \mathrm{ppm}$ in bulk sediments near the drill site in block 410. This concentration is a factor of 5.9 times higher than the predrilling concentration at that location. This maximum postdrilling barium concentration is within the range of predrilling concentrations $(28-300 \mathrm{ppm})$ measured in various sediment types from the regional stations of this program. No drilling-related changes in the concentrations of chromium or other metals have been observed in bulk sediments at any of the locations sampled in this program to date.

We estimate that between 21 percent and 31 percent of the barite (principal barium-bearing mineral) discharged at block 312 was present in the sediments within $6 \mathrm{~km}$ of the rig, 4 weeks after drilling was completed. The barite deposited near this well was found to decrease in concentration with a half-life of 0.4 year. At this rate, the average barium concentration in sediments within $6 \mathrm{~km}$ of the drilling rig in block 312 is expected to be only 10 percent higher than the predrilling concentration within approximately 1.5 years. Although the inventory of the barite discharged on Georges Bank is based on only a few data points, most (approximately 69 percent) of the barite discharged by the eight exploratory wells apparently can be found in sediments west of the drilling locations. The increase in barium concentration above background can be measured in the fine fraction of sediment at a distance of $65 \mathrm{~km}$ to the west of block 312. Analysis of sediment-trap samples collected $25 \mathrm{~m}$ above the bottom in block 312 indicates that the dispersion of barium-rich fine sediment is enhanced by resuspension from the sea floor and transport to the west with the mean current flow.

Evidence exists of small accumulations of barium near the heads of Lydonia and Oceanographer Canyons. However, the increased concentrations can be defined only by analyzing the fine fraction of sediment.
\end{abstract}

\section{INTRODUCTION}

This study was designed to establish the concentrations of trace metals in sediments prior to drilling on Georges Bank and to quantify the changes in concentrations that are related to petroleum-exploration activities. Some of the specific questions addressed are (1) Where do discharged drilling muds accumulate on Georges Bank? (2) How much do trace metals increase as a result of accumulating drilling mud? (3) In areas where drilling-mud components increase, how long do they remain at an elevated concentration after the drilling is completed?

This U.S. Geological Survey (USGS) effort supports the main thrust of the Georges Bank Monitoring Program; that is, to evaluate adverse effects of drilling effluents on bottom-dwelling organisms. The other studies within the Georges Bank Monitoring Program include (1) the analysis of benthic infauna, conducted by Battelle New England Laboratories and the Woods Hole Oceanographic Institution, (2) the analysis of hydrocarbons in bottom sediments and the analysis of hydrocarbons and trace metals in benthic fauna, conducted by Scientific Applications, Inc., and (3) the analysis of previous benthic infauna samples from Georges Bank by Taxon, Inc. (Michael and others, 1983). The concentrations of contaminants in commercially important species of fish and shellfish on Georges Bank have been determined in ongoing programs conducted by the National 
Oceanic and Atmospheric Administration (Cooper and Uzmann, 1981). This report is based on data generated by the USGS during the first 2 years of what is expected to be at least a 3-year program. Tabulation and interpretation of data obtained in the first year of monitoring are reported by Bothner and others (1984)

The first cruise of the monitoring program occurred just before exploratory drilling commenced in July 1981, and subsequent cruises have been conducted on a seasonal basis (November, February, May, and July) since that time. On each cruise, samples were collected at regional stations 1 through 18 (fig. $1 A$ ) and at 29 site-specific stations (fig. $1 B$ ). Regional stations 19,20 , and 21 were added to the program during the July 1983 cruise. The regional stations were positioned to evaluate changes with time over different environments within the entire region. For example, stations 13 and $13 \mathrm{~A}$ are thought to be areas of deposition for material winnowed from Georges Bank (Bothner and others, 1981; Twichell and others, 1981), as are stations 14 and $14 \mathrm{~A}$ in the Gulf of Maine and stations 7A and 9 in the heads of Lydonia and Oceanographer Canyons. Station 15 is in an area of eroding coarse sediment. Given the mean current flow to the west on the southern flank of Georges Bank (Butman and others, 1982a), the stations in transect I (stations 1, 2, and 3) are considered to be upstream controls for stations among the major lease blocks (transect II) and for stations downstream of the lease blocks (transect III). (Station 13A is a new station added on cruise 4. The positions of stations 7 and 14 were changed in the second year of the program to locations labeled 7A and 14A; see fig. 1A.)

The site-specific survey, designed to monitor changes close to a rig, was centered around the platform operated by Mobil in block 312 (regional station 5), where drilling took place between December 1981 and June 1982. A less detailed local survey was conducted with three stations (regional stations 16, 17, and 18) near the Shell Oil Company platform that operated in block 410 between July 1981 and March 1982.

In total, eight exploratory wells have been drilled to date on Georges Bank. The first was started on July 22, 1981, and the last well was completed on September 27, 1982. Each of the exploratory wells was classified as a dry hole.
There has been no additional drilling of any kind on Georges Bank in the period ending on the date of this report.

The analysis of trace-metal data discussed in this report identifies the general trends that exist both in time and space since exploratory drilling of any kind began on Georges Bank. The data have been entered into a computer data base for retrieval and have been listed on magnetic tape. Navigation data for each sample analyzed for chemistry are compiled in appendix tables $1 \mathrm{~A}$ and $1 B$.

\section{FIELD SAMPLING AND SAMPLE PREPARATION}

Special steps were taken to minimize contamination of sediment samples at sea. The samples for chemical analyses were collected with a $0.1-\mathrm{m}^{2}$ stainless steel Van Veen grab sampler with teflon coating on all surfaces in contact with sediment. A polyethylene-coated cable was used to lower the grab to the sea floor. Upon recovery of a sample, the overlying water was siphoned off with a glass tube, and the upper $2 \mathrm{~cm}$ of material were (1) collected with a noncontaminating utensil, (2) placed in an acid-washed polyethylene container, and (3) frozen until analyzed. Because individual grab samples were subsampled for both trace-metal and hydrocarbon analyses, the grab sampler was rinsed with distilled methanol and hexane before each use.

Sediment cores were collected on other LSGS cruises in the study area with a hydraulically damped gravity corer similar to the one described by Pamatmat (1971). This apparatus has a slow rate of penetration controlled by a water-filled piston and collects cores as long as $70 \mathrm{~cm}$ (in mud) with minimal disturbance of the sediment. Cores containing the undisturbed water-sediment interface were collected in thin-walled fiberglass core barrels and were frozen after collection. The samples were later extruded, thawed, and cut into 1-cm sections for analysis.

The depth distribution of metals also was determined on samples removed in $2-\mathrm{cm}$ depth intervals from grab samples.

In the laboratory, the samples were thawed, homogenized, and subsampled under a particle-free hood. Aliquots from individual grabs and sample blends, made up of equal weights from the individual grabs, were separated for chemical and 
textural analyses. Samples for chemical analyses were dried to a constant weight at $70^{\circ} \mathrm{C}$ in an oven with teflon-coated surfaces and a filtered nitrogen atmosphere. Dried samples were ground in an agate grinder after shell or sediment particles larger than $2 \mathrm{~mm}$ were removed. Drill cuttings, identified by their angular edges and unusual color, were not removed. These samples are referred to as bulk sediments (undifferentiated with respect to size) throughout this report.

To maximize the analytical resolution in identifying drilling mud components, sand and coarser material were removed from selected samples. Distilled water was used to wash the silts and clays through a nylon sieve that had $60-\mu \mathrm{m}$ openings. The resultant slurry was dried in a teflon-coated oven, then ground and analyzed by the same methods used for bulk sediments. Corrections were made for the weight of salt contributed by the interstitial water.

The field numbers (for example, M06-13-00-G and M07-05-28-BL) that identify samples in each data table have the following code. The first three characters indicate the cruise number; M06 stands for monitoring cruise 6 . The station number appears after the first dash. In the examples given, 13-00 is a station in the regional sample array; station 05-28 is one of the site-specific stations around regional station 5 (see fig. $1 B$ ). A single alpha character at the end of the field number identifies one of three replicates taken at each station for trace-metal analysis. Alternatively, the notation BL at the end of the field number indicates a blended composite sample made up of equal weights from each of the three replicates. Field numbers ending in $\mathrm{X}$ indicate that analyses were performed on the fraction of sediment finer than 60- $\mu \mathrm{m}$.

\section{GRAIN-SIZE ANALYSIS TECHNIQUES}

Textural analyses were performed on wet sediments to avoid the formation of clay aggregates. Homogenized samples were wet sieved by using a dispersant (5-percent Calgon) through a $63-\mu \mathrm{m}$ sieve to remove silt and clay. The coarse fraction (containing shells, if present) was dried, weighed, and then sieved through a $2-\mathrm{mm}$ screen to remove the gravel, which was not further sized. The sand fraction was analyzed with a Rapid Sediment Analyzer (Schlee, 1966). A gravimetric determination of the silts and clays was made by filtering. The size distribution of the silts and clays was determined with a Coulter Counter. Statistical parameters (mean, median, standard deviation, and so forth) were determined by the method of moments (Krumbein and Pettijohn, 1938). All textural data are expressed in phi $(\phi)$ units, which are defined as $-\log _{2} D$ where $D$ is the grain diameter in millimeters.

Samples obtained from sediment cores and sediment traps were not analyzed by rapid sediment analyses because of insufficient sample size. These samples were passed through a sequence of sieves. The percentage of the major textural classes was determined gravimetrically. Textural classes finer than $63-\mu \mathrm{m}$ were determined with a Coulter Counter.

\section{TRACE-METAL ANALYSIS PROCEDURES}

The analyses of trace metals in marine sediments were carried out by the U.S. Geological Survey Branch of Analytical Laboratories, Reston, Va. Concentrations of the following elements were determined: aluminum ( $\mathrm{Al}$ ), barium (Ba), cadmium (Cd), chromium $(\mathrm{Cr})$, copper $(\mathrm{Cu})$, iron $(\mathrm{Fe})$, lead $(\mathrm{Pb})$, manganese $(\mathrm{Mn})$, mercury $(\mathrm{Hg})$, nickel $(\mathrm{Ni})$, vanadium $(\mathrm{V})$, and zinc $(\mathrm{Zn})$. The various procedures employed in each of the analyses are detailed below and summarized in table 1.

\section{PREPARATION OF STOCK SOLUTION A}

Approximately $0.5 \mathrm{~g}$ of ground bulk sediment or $0.2 \mathrm{~g}$ of the fine fraction was added to a covered teflon beaker and digested overnight with $5 \mathrm{~mL}$ of $\mathrm{HClO}_{4}, 5 \mathrm{~mL}$ of $\mathrm{HNO}_{3}$, and $15 \mathrm{~mL}$ of $\mathrm{HF}$ at approximately $140^{\circ} \mathrm{C}$. The covers were removed, and the temperature was increased to between $180^{\circ}$ and $190^{\circ} \mathrm{C}$, first producing fumes of $\mathrm{HClO}_{4}$ and then evaporating the solution to dryness. The residue was dissolved and diluted to exactly $25 \mathrm{~mL}$ with $8 \mathrm{~N} \mathrm{HCl}$. This solution is referred to as stock solution $\mathrm{A}$.

Two blanks containing all reagents were analyzed along with samples. All reagents were analyzed for contaminants prior to use, as is always necessary. The Canadian reference sediment standard MESS-1 was analyzed in each set of samples. A series of solutions was prepared that approximated the concentration levels expected in the samples; this series was used as the standard in 


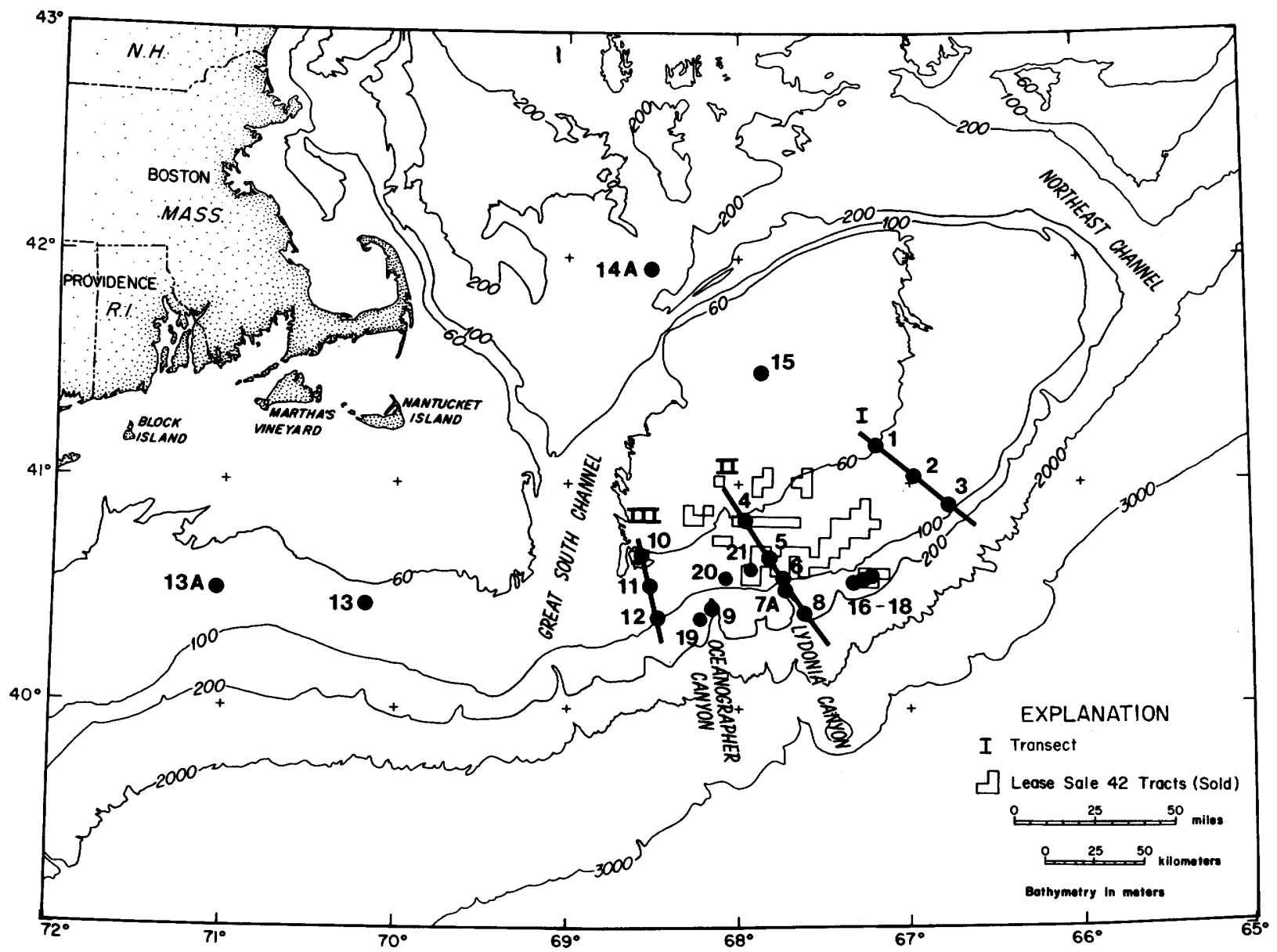

Figure 1A.--Regional sampling station array. Site-specific array in block 312 is centered at station 5.

calibrating the inductively coupled plasma (ICP) spectrometer and atomic absorption (AA) spectrophotometer.

\section{PREPARATION OF STOCK SOLUTION B}

Stock solution B was made by adding $10 \mathrm{~mL}$ of butyl acetate (distilled to remove impurities such as copper) to $15 \mathrm{~mL}$ of stock solution $\mathrm{A}$ in a $60-\mathrm{mL}$ separatory funnel. This solution was vigorously agitated by an automatic shaker for 6 minutes to extract iron. The layers were separated, and the extraction step was repeated with an additional 10 $\mathrm{mL}$ of butyl acetate. The aqueous layer was evaporated to dryness at $150^{\circ} \mathrm{C}$ in a $50-\mathrm{mL}$ beaker. The residue was dissolved and diluted to $25 \mathrm{~mL}$ with $1 N \mathrm{HCl}$.

\section{BARIUM}

The measurements for $\mathrm{Ba}$ were made by ICP spectrometry using $2 \mathrm{~mL}$ of stock solution A diluted to $4 \mathrm{~mL}$ with distilled $\mathrm{H}_{2} \mathrm{O}$.

\section{ALUMINUM, IRON, CHROMIUM, NICKEL, AND VANADIUM}

Concentrations of $\mathrm{Al}$ and $\mathrm{Fe}$ were determined by ICP spectrometry by using $1 \mathrm{~mL}$ of stock solution A diluted to $10 \mathrm{~mL}$ with $\mathrm{H}_{2} \mathrm{O}$. The measurements for $\mathrm{Cr}, \mathrm{Ni}$, and $\mathrm{V}$ were made by injecting $20 \mu \mathrm{L}$ of diluted (1:10) stock solution A into a graphite-furnace AA spectrophotometer. 


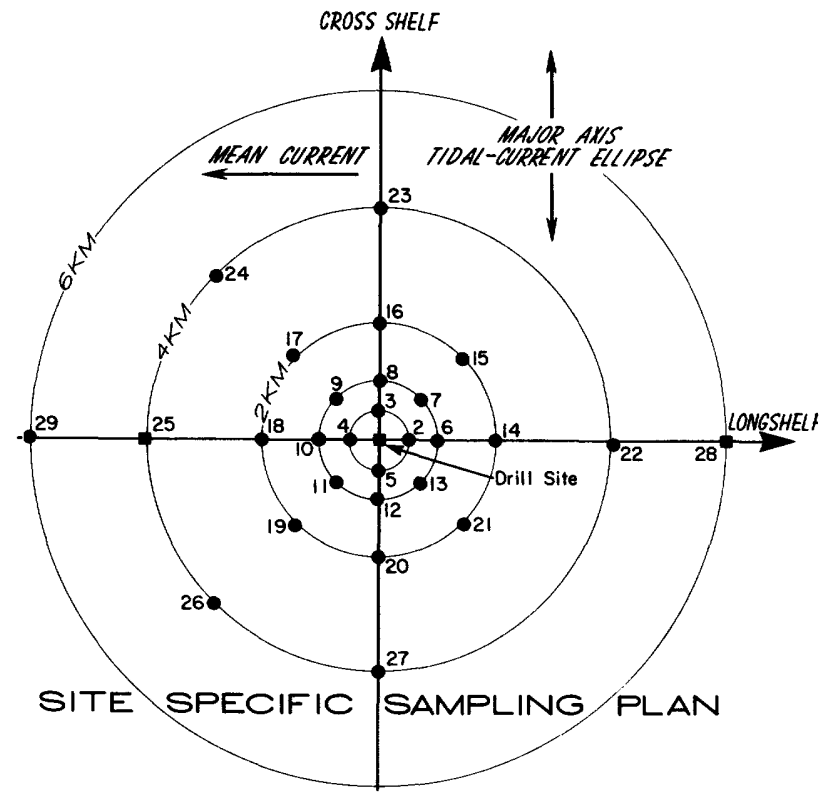

Figure $1 B$.--Site-specific sampling station array around regional station 5 (block 312). Stations 5-7, 5-13, 5-17, 5 $19,5-23,5-24,5-26$, and 5-27 are secondary stations lof lower priority) and have not been analyzed routinely.

\section{LEAD, COPPER, AND CADMIUM}

Fifteen $\mathrm{mL}$ of 0.5 -percent (weight:volume) diethyldithiocarbamic acid diethylammonium salt (DDTC) in chloroform were added to $10 \mathrm{~mL}$ of solution $B$ in a $60-\mathrm{mL}$ separatory funnel and mixed for 10 minutes by an automatic shaker. The chloroform layer was drained into a $30-\mathrm{mL}$ beaker, and the aqueous layer washed with $10 \mathrm{~mL}$ of chloroform. The second chloroform layer was combined with the first, and the total volume of chloroform was evaporated to dryness at $90^{\circ} \mathrm{C}$. The organic matter was destroyed by adding $0.1 \mathrm{~mL}$ of concentrated $\mathrm{HNO}_{3}$ and was evaporated to dryness. This residue then was dissolved in $2 \mathrm{~mL}$ of warm $1 \mathrm{~N}$ $\mathrm{HCl}$. The beaker was rinsed four times with $2-\mathrm{mL}$ portions of distilled $\mathrm{H}_{2} \mathrm{O}$, and the solution was transferred to a small polyethylene container. The measurements for $\mathrm{Pb}, \mathrm{Cu}$, and $\mathrm{Cd}$ were made by injecting $20 \mu \mathrm{L}$ of the final solution into a graphitefurnace AA spectrophotometer.

\section{MANGANESE AND ZINC}

The measurements for Mn were made by ICP spectrometry with a solution made by diluting $2 \mathrm{~mL}$ of stock solution $\mathrm{B}$ to $4 \mathrm{~mL}$ with $\mathrm{H}_{2} \mathrm{O}$. Zinc was measured by flame AA directly from stock solution B.

\section{MERCURY}

Mercury concentration was determined on a separate portion of the sample. Two hundred milligrams of sediment were decomposed in a 1-oz teflon screw-top vial with $2 \mathrm{~mL}$ of concentrated $\mathrm{HNO}_{3}$ and $2 \mathrm{~mL}$ of $\mathrm{HClO}_{4}$. The mixture was heated in a capped vial until the solution reached $200^{\circ} \mathrm{C}$. The solution was then heated with the cap off for about 45 minutes, after which the samples were removed from the heat source. Immediately, $1 \mathrm{~mL}$ of concentrated $\mathrm{HNO}_{3}$ was added; the vial was filled with $\mathrm{H}_{2} \mathrm{O}$ and capped tightly until used. The sample solution then was added to a flask containing $125 \mathrm{~mL}$ of $\mathrm{H}_{2} \mathrm{O}$ and $4 \mathrm{~mL}$ of 10-percent (weight:volume) $\mathrm{SnCl}_{2}$ in 20 -percent $\mathrm{HCl}$. Nitrogen was passed through the solution to remove elemental $\mathrm{Hg}$, which was collected on gold foil located in the center of the coils of an induction furnace. Activation of the furnace released the $\mathrm{Hg}$, which was measured by a cold-vapor AA technique. Blanks, standard rocks, and internal sediment standards were analyzed for each set of samples. A series of solutions was prepared that had the same $\mathrm{Hg}$-concentration range expected in the samples.

The concentrations of $\mathrm{Hg}$ in bottom sediments determined during the first year of the monitoring program were typically less than the detection limit of $0.01 \mathrm{ppm}$. During the second year of monitoring, we tested new procedures designed to lower the detection limit.

The contribution of $\mathrm{Hg}$ from various brands of nitric acid was determined. Baker "analyzed reagent grade" contained 0.7 to 0.8 parts per billion (ppb) $\mathrm{Hg}$, the lowest concentration of the acids tested. Baker "ultrex" contained $2 \mathrm{ppb} \mathrm{Hg}$, and Mallinckrodt nitric acid contained $1.3 \mathrm{ppb} \mathrm{Hg}$. The $\mathrm{Hg}$ concentration of each new bottle of nitric acid and of every other reagent was determined before the reagent was used for analysis. The $\mathrm{Hg}$ contribution from the combined reagents was $1.5 \mathrm{ng}$ $\pm 0.2 \mathrm{ng}$.

We tried to lower the detection limit by increasing the sample size. Subsamples weighing $1 \mathrm{~g}$ were analyzed with various combinations of nitric and perchloric acids. The results were not encouraging because digestion was incomplete with small acid volumes or because blanks were too 


\begin{tabular}{|c|c|c|c|c|c|}
\hline Element & Inst rument & Instrument conditions & $\begin{array}{l}\text { Extraction } \\
\text { procedure }\end{array}$ & $\begin{array}{c}\text { Procedure } \\
\text { determination } \\
\text { 1Imit in sample, } \\
\mu \mathrm{g} / \mathrm{g} \\
\end{array}$ & $\begin{array}{l}\text { Average blanks, } \\
\text { as measured in } \\
\mu \mathrm{g} / \mathrm{g} \text { in solution }\end{array}$ \\
\hline Al- - - & ICP (argon)- & $\begin{array}{l}308.2 \mathrm{~nm} \\
\text { FP (Forward power) }=1.1 \mathrm{kw} \\
\text { Fixed cross flow nebulizer } \\
\text { Spectral band width } 0.036 \mathrm{~nm} \\
\text { Observation height } 16 \mathrm{~mm} \text {. }\end{array}$ & None----- & - 50 & 0.02 \\
\hline Ba-- - - - & ICP (argon)---- & $\begin{array}{l}455.4 \mathrm{~nm} \\
\text { FP=1.1 kw } \\
\text { Fixed cross flow nebulizer } \\
\text { Spectral band width } 0.036 \mathrm{~nm} \\
\text { observation height } 16 \mathrm{~mm} .\end{array}$ & None----------- & -----20 & .01 \\
\hline Cd------- & $\begin{array}{l}\text { Graphite } \\
\text { furnace AA. }\end{array}$ & $\begin{array}{l}110^{\circ} \mathrm{C} \text { dry temperature } \\
250^{\circ} \mathrm{C} \text { char temperature } \\
2100^{\circ} \mathrm{C} \text { atom temperature } \\
\text { Regular graphite tube } \\
\text { Interrupt gas flow } \\
\text { W. } 1 .=228.8 \mathrm{~nm} \\
\mathrm{~S} 11 \mathrm{t}=0.7 \mathrm{~nm} .\end{array}$ & $\begin{array}{l}\text { Buty1 acetate } \\
\text { and DDTC. }\end{array}$ & 0.02 & .0002 \\
\hline $\mathrm{Cr}-\infty--$ & $\begin{array}{l}\text { Graphite } \\
\text { furnace AA. }\end{array}$ & $\begin{array}{l}110^{\circ} \mathrm{C} \text { dry temperature } \\
900^{\circ} \mathrm{C} \text { char temperature } \\
2700^{\circ} \mathrm{C} \text { atom temperature } \\
\text { Regular graphite tube } \\
\text { Normal gas flow (low) } \\
\text { W.1. }=357.9 \mathrm{~nm} \\
\text { S11t }=0.7 \mathrm{~nm} .\end{array}$ & None--_--- & ------3 & .003 \\
\hline $\mathrm{Cu}----\infty$ & $\begin{array}{l}\text { Graphite } \\
\text { furnace } A A .\end{array}$ & $\begin{array}{l}110^{\circ} \mathrm{C} \text { dry temperature } \\
900^{\circ} \mathrm{C} \text { char temperature } \\
2700^{\circ} \mathrm{C} \text { atom temperature } \\
\text { Regular graphite tube } \\
\text { Interrupt gas flow } \\
\text { W. } 1 .=324.7 \mathrm{~nm} \\
\text { S11t }=0.7 \mathrm{~nm} .\end{array}$ & $\begin{array}{l}\text { Butyl acetate } \\
\text { and DDTC. }\end{array}$ & 1 & .005 \\
\hline $\mathrm{Fe}------$ & ICP (argon) - - & $\begin{array}{l}259.9 \mathrm{~nm} \\
\text { FP=1.1 kw } \\
\text { Fixed cross flow nebulizer } \\
\text { Spectral band width } 0.036 \mathrm{~nm} \\
\text { Observation height } 16 \mathrm{~nm} .\end{array}$ & None----------- & -----50 & .02 \\
\hline Hg---- -- & $\begin{array}{l}\text { Induction } \\
\text { furnace AA. }\end{array}$ & $\begin{array}{l}\text { Wavelength }=254 \mathrm{~nm} \\
\text { Cold vapor } A A .\end{array}$ & None----------- & 0.005 & 0.005 \\
\hline Mn------ & ICP (argon)---- & $\begin{array}{l}257.6 \mathrm{~nm} \\
\text { FP=1.1 kw } \\
\text { Fixed cross flow nebulizer } \\
\text { Spectral band width } 0.036 \mathrm{~nm} \\
\text { Observation helght } 16 \mathrm{~nm} .\end{array}$ & $\begin{array}{l}\text { Butyl acetate } \\
\text { (removal of iron). }\end{array}$ & 10 & .006 \\
\hline N1-- - - & $\begin{array}{l}\text { Graphite } \\
\text { furnace AA. }\end{array}$ & $\begin{array}{l}110^{\circ} \mathrm{C} \text { dry temperature } \\
900^{\circ} \mathrm{C} \text { char temperature } \\
2700^{\circ} \mathrm{C} \text { atom temperature } \\
\text { Pyrolytic tube } \\
\text { Normal gas flow (1ow) } \\
\text { W.1.=232.0 nm } \\
\text { S11t }=0.2 \mathrm{~nm} .\end{array}$ & None--_-_-_- & ------2 & .02 \\
\hline $\mathrm{Pb}------$ & $\begin{array}{l}\text { Graphite } \\
\text { furnace AA. }\end{array}$ & $\begin{array}{l}110^{\circ} \mathrm{C} \text { dry temperature } \\
900^{\circ} \mathrm{C} \text { char temperature } \\
2700^{\circ} \mathrm{C} \text { atom temperature } \\
\text { Regular graphite tube }\end{array}$ & $\begin{array}{l}\text { Buty1 acetate } \\
\text { and DDTC. }\end{array}$ & 2 & .02 \\
\hline
\end{tabular}




\begin{tabular}{|c|c|c|c|c|c|}
\hline Element & Instrument & Instrument conditions & $\begin{array}{l}\text { Extraction } \\
\text { procedure }\end{array}$ & $\begin{array}{c}\text { Procedure } \\
\text { letermination } \\
\text { limit in sample, } \\
\mu \mathrm{g} / \mathrm{g}\end{array}$ & $\begin{array}{l}\text { Average blanks, } \\
\text { as measured in } \\
\mu \mathrm{g} / \mathrm{g} \text { in solution }\end{array}$ \\
\hline & & $\begin{array}{l}\text { Interrupt gas flow } \\
W .1=283.3 \\
\text { S1it }=0.7 \mathrm{~nm} .\end{array}$ & & & \\
\hline v-- - & $\begin{array}{l}\text { Graphite } \\
\text { furnace AA. }\end{array}$ & $\begin{array}{l}110^{\circ} \mathrm{C} \text { dry temperature } \\
1000^{\circ} \mathrm{C} \text { char temperature } \\
2800^{\circ} \mathrm{C} \text { atom temperature } \\
\text { Pyrolyt c curtin tube } \\
\text { Normal gas flow (high) } \\
W .1 .=318.4 \mathrm{~nm} \\
\text { S1it }=0.7 \mathrm{~nm} .\end{array}$ & None----- & ------3 & .002 \\
\hline $\mathrm{Zn}-\cdots-\cdots$ & Flame AA.-- & $\begin{array}{l}\text { Oxidizing; air-acetylene } \\
\quad \text { flame } \\
\text { W.1. }=213.9 \\
\text { Sift }=0.7 \mathrm{~nm} .\end{array}$ & Buty1 acet & ------1 & .01 \\
\hline
\end{tabular}

high when large acid volumes were used. The high sediment concentration in suspension during the gas-stripping procedure may have adsorbed some of the $\mathrm{Hg}$, accounting for the lower concentration measured for large samples.

Another method of increasing sample size involved successive plating of $\mathrm{Hg}$ vapor from three $200-\mathrm{mg}$ aliquots onto the gold foil of the induction furnace. This technique yielded poor reproducibility among replicates and decreased the number of samples that could be analyzed in a day by a factor of 3 .

The selection of reagents having the lowest $\mathrm{Hg}$ concentration and optimization of the optical system in the cold-vapor AA detection system (manufactured by Laboratory Data Control, Inc.) reduced the detection limit of our procedure from $0.01 \mathrm{ppm}$ to $0.005 \mathrm{ppm}$. We are independently continuing the research to reduce the detection limit further.

The magnitude of $\mathrm{Hg}$ lost while oven drying sediment samples also was evaluated. Aliquots of bulk sediments from station M06-13A were analyzed wet, and the results compared to samples that were oven dried at different temperatures. We found no evidence of $\mathrm{Hg}$ loss as a result of drying at temperatures between $40^{\circ}$ to $100^{\circ} \mathrm{C}$ (table 2 ).

We observed the same concentration of $\mathrm{Hg}$ in aliquots of the station M05-16 fine fraction that had been dried in the temperature range of $40^{\circ}$ to $80^{\circ} \mathrm{C}$. However, a loss of about 42 percent was measured in aliquots dried at $100^{\circ} \mathrm{C}$, compared to concentrations observed at lower temperatures. The $\mathrm{Hg}$ lost from the fine fraction at $100^{\circ} \mathrm{C}$ may be distributed differently among various sediment components than the $\mathrm{Hg}$ in the bulk sediment. We concluded that the process of drying samples at temperatures of $80^{\circ} \mathrm{C}$ or less does not volatilize $\mathrm{Hg}$ from either the fine fraction or bulk sediments from Georges Bank. These results may not be applicable to sediments of different texture or composition from other areas.

\section{ADDITIONAL METHODS}

Results of $\mathrm{Ba}$ and $\mathrm{Cr}$ analyses on selected Georges Bank samples were cross-checked by an energy-dispersive $X$-ray fluorescence technique (Johnson, 1984). The determination of $\mathrm{Ba}$ concentration was made with a Kevex 0700 energydispersive X-ray fluorescence spectrometer. Powdered samples of about $1 \mathrm{~g}$ were analyzed with a gadolinium secondary target for excitation of the $\mathrm{K}$-alpha line. The ratio of $\mathrm{Ba}$ intensity to the gadolinium Compton scatter intensity was used to correct for absorption effects. This ratio then was compared to a standard calibration curve to determine the concentration of $\mathrm{Ba}$.

The X-ray fluorescence technique was used on all samples found to have more than $500 \mathrm{ppm} \mathrm{Ba}$ in the first analysis by acid decomposition and ICP spectrometry. The X-ray fluorescence technique is highly accurate in samples enriched with $\mathrm{BaSO}_{4}$, which is difficult to dissolve completely. Justification of the alternative method is presented in Bothner and others (1984). 


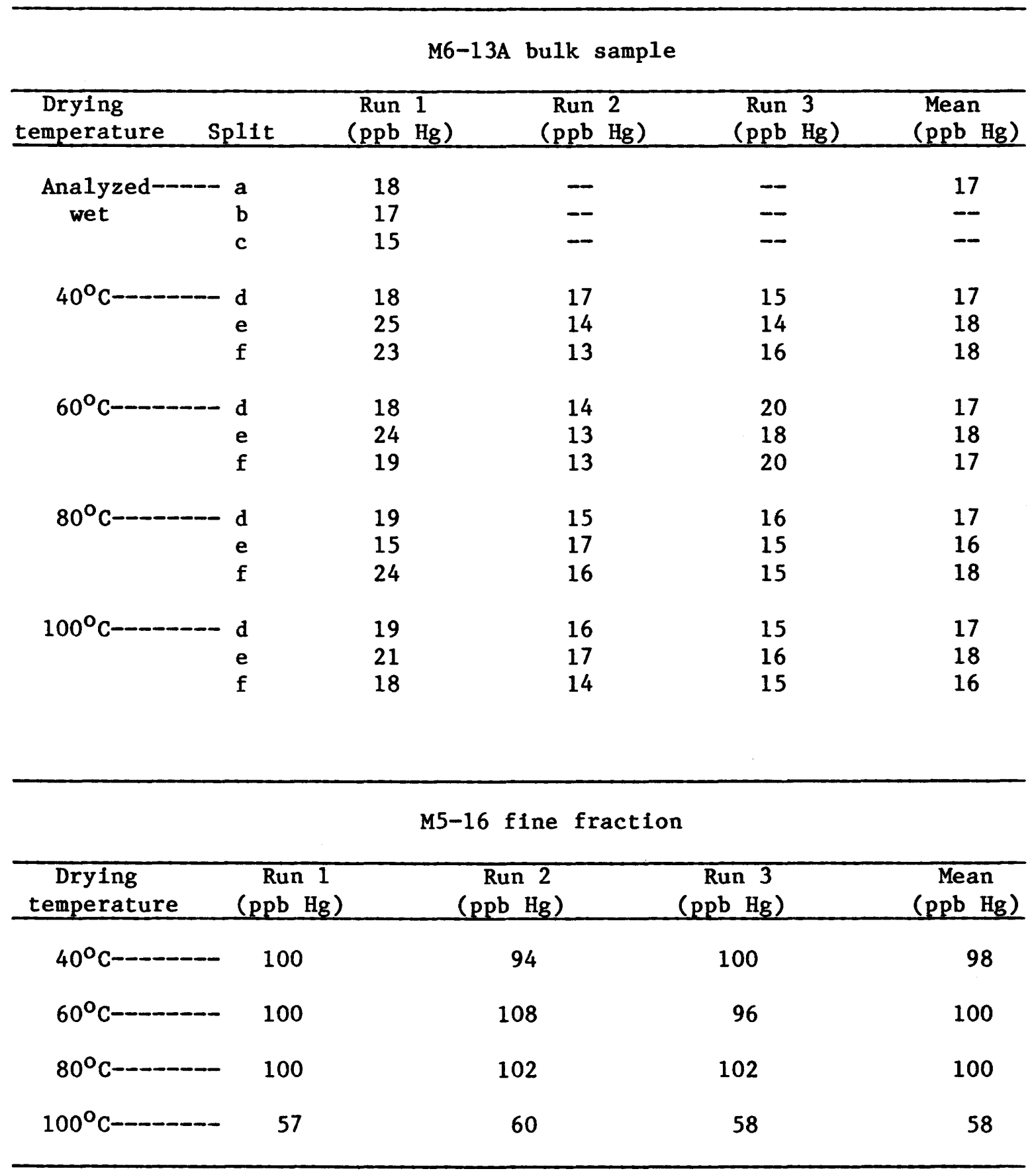

\section{ANALYTICAL ACCURACY AND PRECISION}

Analytical accuracy was determined by analyzing rock standard MESS-1. Excellent agreement occurs between our results and values established by other laboratories (table 3 ).
Excellent agreement also exists among aliquots of samples submitted as blind replicates (appendix table 2).

Analytical precision was determined by periodically analyzing replicate aliquots taken from a single sample. Coefficients of variation 
shown in table 3 indicate that the standard deviation is typically less than 10 percent of the mean value, except for concentrations at or near the detection limit of the method.

To maintain our internal quality control and to provide typical sample material for interlaboratory comparisons, four sediment standards representing different textural types were prepared from large samples of Georges Bank sediment. The levels of trace metals are being established by several analytical methods. Splits of these materials are available to those interested in cross-calibration studies.

\section{RESULTS AND DISCUSSION}

\section{SEDIMENT TEXTURE}

The texture of the surface sediments in the second year of monitoring (appendix table 3A) is very similar to the texture measured in the first year (fig. 2) as defined by the average mean $\phi$ values at each station for a given year. Low yearly variability of the mean grain sizes occurs, as demonstrated by the close match of the data patterns. Mean $\phi$ values range from about $1 \phi$ (coarse sand) at station 5-1 to about 6.3 (medium silt) at station 13A located south of Martha's Vineyard. The error bars (standard deviation about the mean of samples from each of four seasons) indicate that the within-station variability is much smaller than the betweenstation variability.

The sediments on Georges Bank are typically greater than 95 percent sand and contain minor amounts of gravel, silts, and clays. The sand is quartzose, is primarily medium to coarse grained, and ranges in coloration from a clear or translucent yellow to a tan iron-oxide stain; it has an angular to subrounded grain shape. On sampling transects I, II, and III (fig. 1A), the content of sediment finer than $63 \mu \mathrm{m}$ (silt plus clay) increases slightly toward the shelf edge.

The concentration of silts and clays in the regional samples was generally less than 4 percent (fig. 3), and the mean station values for year 1 were similar to those of year 2 . The relative paucity of silts and clays reflects the strong winnowing processes associated with tidal and storm-generated currents on Georges Bank (Butman and Folger, 1979; Butman and Moody, 1983; Butman and others, 1982a; Parmenter and others, 1984). Areas that showed a significant concentration of fine sediments (finer than $63 \mu \mathrm{m}$ ) during each sampling cruise were located at regional station 14A (80-90 percent fines) in the Gulf of Maine, regional station 7A (25-30 percent fines) at the head of Lydonia Canyon, and regional stations 13 and $13 \mathrm{~A}$ (38-50 and 96.97 percent fines, respectively),

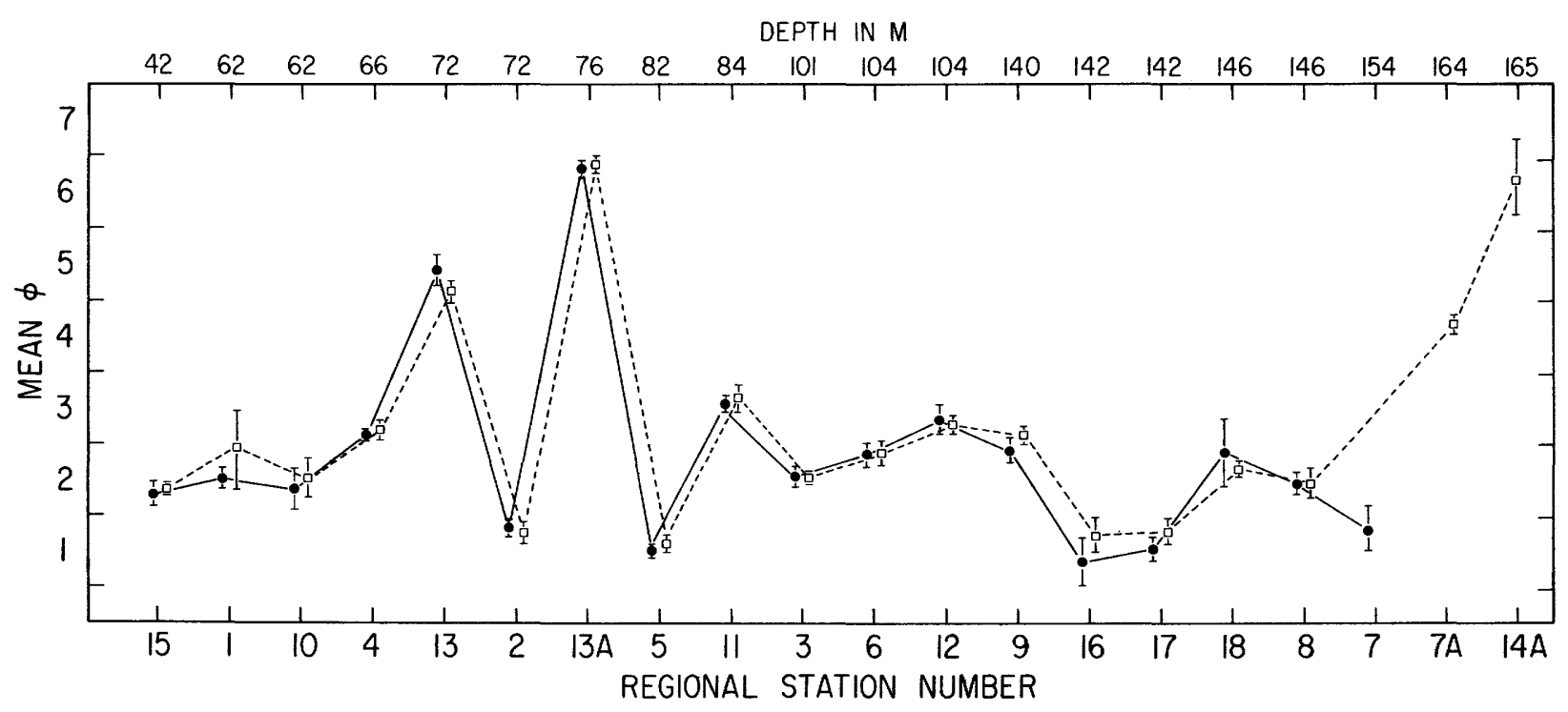

Figure 2.--Mean grain size of samples collected during years 1 (circle) and 2 (square). Error bars represent the standard deviation among samples collected in a given year. Stations are listed in order of increasing water depth. 


\begin{tabular}{|c|c|c|c|c|c|c|c|c|c|c|c|}
\hline $\begin{array}{l}\text { Sample } \\
\text { standard }\end{array}$ & $\begin{array}{c}\mathrm{Al} \\
\text { (percent) }\end{array}$ & $\begin{array}{c}\mathrm{Ba} \\
(\mathrm{ppm}) \\
\end{array}$ & $\begin{array}{c}\text { Cd } \\
(\mathrm{ppm})\end{array}$ & $\begin{array}{c}\mathrm{Cr} \\
(\mathrm{ppm})\end{array}$ & $\begin{array}{c}\mathrm{Cu} \\
(\mathrm{ppm})\end{array}$ & $\begin{array}{c}\mathrm{Fe} \\
\text { (percent) }\end{array}$ & $\begin{array}{c}\text { Mn } \\
(p p m)\end{array}$ & $\begin{array}{c}\mathrm{NI} \\
(\mathrm{ppm}) \\
\end{array}$ & $\begin{array}{c}\mathrm{Pb} \\
(\mathrm{ppm})\end{array}$ & $\begin{array}{c}V \\
(\mathrm{ppm})\end{array}$ & $\begin{array}{c}\mathrm{Zn} \\
(\mathrm{ppm}) \\
\end{array}$ \\
\hline MESS-1-- & $\begin{array}{r}4.10 \\
5.40 \\
5.10 \\
5.30 \\
5.50 \\
5.00 \\
5.20 \\
5.30 \\
5.60 \\
5.20 \\
5.60 \\
5.30\end{array}$ & $\begin{array}{l}260 \\
260 \\
260 \\
280 \\
260 \\
240 \\
250 \\
280 \\
250 \\
250 \\
280 \\
260\end{array}$ & $\begin{array}{l}0.47 \\
.48 \\
.52 \\
.44 \\
.44 \\
.50 \\
.45 \\
.39 \\
.53 \\
.40 \\
.59 \\
.50\end{array}$ & $\begin{array}{l}52 \\
50 \\
53 \\
51 \\
52 \\
51 \\
54 \\
51 \\
49 \\
57 \\
47 \\
49\end{array}$ & $\begin{array}{l}25 \\
27 \\
24 \\
23 \\
22 \\
21 \\
20 \\
22 \\
25 \\
22 \\
25 \\
21\end{array}$ & $\begin{array}{l}2.8 \\
2.9 \\
2.9 \\
2.9 \\
2.9 \\
2.9 \\
2.8 \\
2.9 \\
2.9 \\
2.9 \\
2.8 \\
2.8\end{array}$ & $\begin{array}{l}450 \\
480 \\
480 \\
490 \\
490 \\
470 \\
480 \\
460 \\
480 \\
450 \\
440 \\
480\end{array}$ & $\begin{array}{l}27 \\
35 \\
30 \\
27 \\
27 \\
31 \\
34 \\
28 \\
29 \\
38 \\
25 \\
29\end{array}$ & $\begin{array}{l}41 \\
41 \\
45 \\
40 \\
38 \\
39 \\
36 \\
42 \\
46 \\
39 \\
45 \\
41\end{array}$ & $\begin{array}{l}72 \\
35 \\
80 \\
74 \\
78 \\
78 \\
74 \\
80 \\
82 \\
72 \\
82 \\
75\end{array}$ & $\begin{array}{l}170 \\
170 \\
170 \\
160 \\
160 \\
170 \\
160 \\
170 \\
170 \\
160 \\
160 \\
160\end{array}$ \\
\hline $\begin{array}{l}\bar{x}- \\
\sigma- \\
C v(\%)^{1}-\end{array}$ & $\begin{array}{r}-5.22 \\
-\quad .40 \\
-7.7\end{array}$ & $\begin{array}{r}260.8 \\
13.1 \\
5.1\end{array}$ & $\begin{array}{r}.476 \\
.06 \\
12.6\end{array}$ & $\begin{array}{l}51.3 \\
2.61 \\
5.1\end{array}$ & $\begin{array}{l}23 \\
2.1 \\
9.1\end{array}$ & $\begin{array}{r}2.86 \\
.05 \\
1.7\end{array}$ & $\begin{array}{c}471 \\
16.76 \\
3.6\end{array}$ & $\begin{array}{l}30 \\
3.86 \\
12.8\end{array}$ & $\begin{array}{l}41.1 \\
3.03 \\
7.3\end{array}$ & $\begin{array}{r}73.5 \\
12.6 \\
7.1\end{array}$ & $\begin{array}{c}165 \\
7.07 \\
4.3\end{array}$ \\
\hline Best value & $\begin{array}{r}2.8 \\
-\quad .2\end{array}$ & 270 & $\begin{array}{l}.59 \\
.1\end{array}$ & $\begin{array}{l}71 \\
11\end{array}$ & $\begin{array}{r}25 \\
4\end{array}$ & $\begin{array}{r}3.0 \\
.2\end{array}$ & $\begin{array}{r}513 \\
25\end{array}$ & $\begin{array}{r}30 \\
3\end{array}$ & $\begin{array}{r}34 \\
6\end{array}$ & $\begin{array}{r}72 \\
5\end{array}$ & $\begin{array}{r}191 \\
17\end{array}$ \\
\hline
\end{tabular}

\begin{tabular}{|c|c|c|c|c|c|c|c|c|c|c|c|}
\hline $\begin{array}{l}\text { Replicate } \\
\text { sample }\end{array}$ & $\begin{array}{c}\mathrm{A1} \\
\text { (percent) }\end{array}$ & $\begin{array}{c}\text { Ba } \\
\text { (ppm) }\end{array}$ & $\begin{array}{c}\text { Cd } \\
\text { (ppm) }\end{array}$ & $\begin{array}{c}\mathrm{Cr} \\
(\mathrm{ppm})\end{array}$ & $\begin{array}{c}\mathrm{Cu} \\
(\mathrm{ppm})\end{array}$ & $\begin{array}{c}\text { Fe } \\
\text { (percent) }\end{array}$ & $\begin{array}{c}\text { Mn } \\
\text { (ppm) }\end{array}$ & $\begin{array}{c}\mathrm{Ni} \\
(\mathrm{ppm})\end{array}$ & $\begin{array}{c}\mathrm{Pb} \\
(\mathrm{ppm})\end{array}$ & $\begin{array}{c}V \\
(\mathrm{ppm})\end{array}$ & $\begin{array}{c}\mathrm{Zn} \\
\text { (ppm) }\end{array}$ \\
\hline M8-13A-I- - & $\begin{array}{r}-4.5 \\
4.0 \\
4.7\end{array}$ & $\begin{array}{l}270 \\
280 \\
280\end{array}$ & $\begin{array}{r}0.066 \\
.060 \\
.063\end{array}$ & $\begin{array}{l}59 \\
56 \\
60\end{array}$ & $\begin{array}{l}11 \\
10 \\
11\end{array}$ & $\begin{array}{l}2.5 \\
2.5 \\
2.5\end{array}$ & $\begin{array}{l}270 \\
270 \\
270\end{array}$ & $\begin{array}{l}32 \\
30 \\
32\end{array}$ & $\begin{array}{l}30 \\
30 \\
33\end{array}$ & $\begin{array}{l}80 \\
86 \\
78\end{array}$ & $\begin{array}{l}63 \\
61 \\
62\end{array}$ \\
\hline $\begin{array}{l}\bar{x}- \\
\sigma- \\
\operatorname{cV}(\%)\end{array}$ & $\begin{array}{r}-4.4 \\
-\quad .36 \\
-\quad 8.19\end{array}$ & $\begin{array}{r}276.7 \\
5.77 \\
2.08\end{array}$ & $\begin{array}{l}.063 \\
.003 \\
4.76\end{array}$ & $\begin{array}{l}58.3 \\
2.08 \\
3.57\end{array}$ & $\begin{array}{r}10.66 \\
.58 \\
5.42\end{array}$ & $\begin{array}{l}2.5 \\
0 \\
0\end{array}$ & $\begin{array}{r}270 \\
0 \\
0\end{array}$ & $\begin{array}{r}31.33 \\
1.15 \\
3.69\end{array}$ & $\begin{array}{l}31 \\
1.73 \\
5.59\end{array}$ & $\begin{array}{r}81.33 \\
4.16 \\
5.12\end{array}$ & $\begin{array}{l}62 \\
1 \\
1.61\end{array}$ \\
\hline $\mathrm{M} 6-5-1-\mathrm{BL}-$ & $\begin{array}{r}-0.29 \\
.29 \\
.29 \\
.29 \\
.29\end{array}$ & $\begin{array}{l}84 \\
85 \\
84 \\
85 \\
85\end{array}$ & $\begin{array}{l}<0.02 \\
<.02 \\
<.02 \\
<.02 \\
<.02\end{array}$ & $\begin{array}{l}6.0 \\
6.5 \\
6.5 \\
6.0 \\
6.5\end{array}$ & $\begin{array}{l}<1 \\
<1 \\
<1 \\
<1 \\
<1\end{array}$ & $\begin{array}{r}0.41 \\
.41 \\
.40 \\
.41 \\
.41\end{array}$ & $\begin{array}{l}260 \\
260 \\
260 \\
260 \\
260\end{array}$ & $\begin{array}{l}<2 \\
<2 \\
<2 \\
<2 \\
<2\end{array}$ & $\begin{array}{l}7.1 \\
7.6 \\
8.0 \\
6.6 \\
7.6\end{array}$ & $\begin{array}{r}9.5 \\
12.0 \\
9.2 \\
9.2 \\
12.0\end{array}$ & $\begin{array}{l}6.6 \\
6.6 \\
7.1 \\
7.1 \\
6.6\end{array}$ \\
\hline $\begin{array}{l}\bar{x}- \\
\sigma \quad \\
C V(\%)\end{array}$ & $\begin{array}{l}-0^{.29} \\
-0\end{array}$ & $\begin{array}{c}84.6 \\
.55 \\
.6\end{array}$ & $\begin{array}{l}<.02 \\
0 \\
0\end{array}$ & $\begin{array}{l}6.3 \\
.27 \\
4.3\end{array}$ & $\begin{array}{r}<1 \\
0 \\
0\end{array}$ & $\begin{array}{c}40.8 \\
.45 \\
1.1\end{array}$ & $\begin{array}{r}260 \\
0 \\
0\end{array}$ & $\begin{array}{r}<2 \\
0 \\
0\end{array}$ & $\begin{array}{c}7.38 \\
.54 \\
7.3\end{array}$ & $\begin{array}{c}10.38 \\
1.48 \\
14.3\end{array}$ & $\begin{array}{l}6.8 \\
.27 \\
4.0\end{array}$ \\
\hline M6-1-BL- - & $\begin{array}{r}0.79 \\
.79 \\
.79 \\
.77 \\
.77\end{array}$ & $\begin{array}{l}120 \\
120 \\
120 \\
120 \\
120\end{array}$ & $\begin{array}{c}0.021 \\
3<.023 \\
<.02 \\
.021 \\
.023\end{array}$ & $\begin{array}{l}5.0 \\
5.0 \\
5.0 \\
5.0 \\
5.0\end{array}$ & $\begin{array}{l}1.7 \\
1.2 \\
2.7 \\
1.7 \\
1.2\end{array}$ & $\begin{array}{r}0.41 \\
.41 \\
.41 \\
.41 \\
.41\end{array}$ & $\begin{array}{l}94 \\
92 \\
94 \\
92 \\
92\end{array}$ & $\begin{array}{l}<1 \\
<1 \\
<1 \\
<1 \\
<1\end{array}$ & $\begin{array}{l}5.7 \\
4.8 \\
5.1 \\
6.2 \\
4.5\end{array}$ & $\begin{array}{l}7.0 \\
7.0 \\
7.0 \\
7.0 \\
7.0\end{array}$ & $\begin{array}{l}8.1 \\
8.4 \\
7.5 \\
7.5 \\
7.5\end{array}$ \\
\hline $\begin{array}{l}\bar{x}- \\
\sigma v(\%)\end{array}$ & $\begin{array}{l}-.78 \\
-\quad .01 \\
-1.3\end{array}$ & $\begin{array}{r}120 \\
0 \\
0\end{array}$ & $\begin{array}{l}.022 \\
.001 \\
4.5\end{array}$ & $\begin{array}{l}5.0 \\
0 \\
0\end{array}$ & $\begin{array}{c}1.7 \\
36^{.61}\end{array}$ & $\begin{array}{l}0^{.41} \\
0\end{array}$ & $\begin{array}{l}92.8 \\
1.09 \\
1.1\end{array}$ & $\begin{array}{r}<1 \\
0 \\
0\end{array}$ & $\begin{array}{r}5.26 \\
13^{.69}\end{array}$ & $\begin{array}{l}7.0 \\
0 \\
0\end{array}$ & $\begin{array}{l}7.8 \\
.42 \\
5.4\end{array}$ \\
\hline $0 C-122-64--$ & $\begin{array}{r}0.26 \\
.26 \\
.26 \\
.26 \\
.26\end{array}$ & $\begin{array}{l}36 \\
36 \\
35 \\
37 \\
36\end{array}$ & $\begin{array}{r}<0.02 \\
<.02 \\
<.02 \\
<.02 \\
<.02\end{array}$ & $\begin{array}{l}5.5 \\
5.3 \\
5.5 \\
5.0 \\
5.0\end{array}$ & $\begin{array}{l}<1 \\
<1 \\
<1 \\
<1 \\
<1\end{array}$ & $\begin{array}{r}0.47 \\
.47 \\
.47 \\
.47 \\
.47\end{array}$ & $\begin{array}{l}420 \\
420 \\
420 \\
420 \\
420\end{array}$ & $\begin{array}{l}<2 \\
<2 \\
<2 \\
<2 \\
<2\end{array}$ & $\begin{array}{l}5.5 \\
4.8 \\
4.6 \\
4.8 \\
5.3\end{array}$ & $\begin{array}{l}14 \\
14 \\
14 \\
15 \\
13\end{array}$ & $\begin{array}{l}5.8 \\
5.8 \\
5.8 \\
5.8 \\
5.8\end{array}$ \\
\hline
\end{tabular}


Table 3.--Analysis of sediment standard and replicate sediment samples--Continued

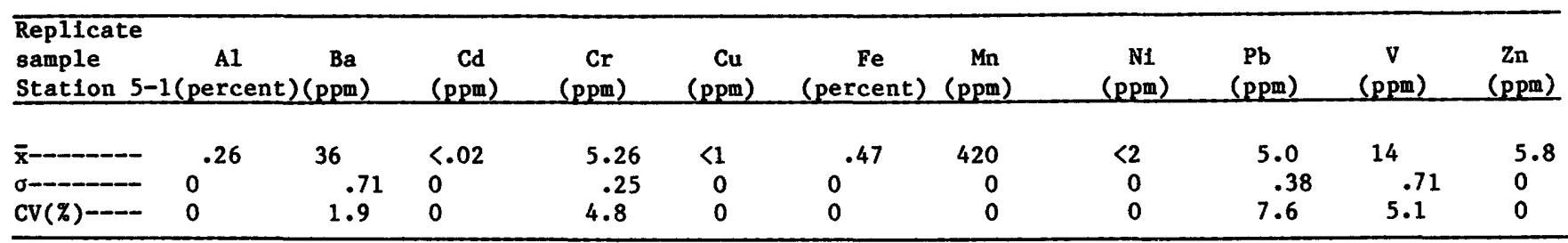

${ }^{1}$ Coefficient of variation.

2 Values reported by the Marine Analytical Chemistry Standards Program, National Research Counc1l, Canada.

${ }^{3}$ Value left out when calculating statistics.

located south of Nantucket Island. This last area, known as the Mud Patch, is thought to be one of the depositional sites for sediments from upstream areas on Georges Bank (Bothner and others, 1981; Twichell and others, 1981). The close correlation between the concentration of fine sediment, organic carbon, and trace metals is discussed in the report for year 1, U.S. Geological Survey Circular 915 (Bothner and others (1984).

The gravel fraction is variable, and concentrations range from 0 to almost 20 percent (appendix table 3A). The gravel is composed of rock fragments or shell hash or a mixture of both. Drill cuttings were observed in the gravel fraction at the drill sites in blocks 312 and 410 . A few cuttings were found at station $17,2 \mathrm{~km}$ to the east of the drill site in block 410 . On the M9 cruise, cuttings were observed at all stations within $500 \mathrm{~m}$ of the drill sites in block 312. The cuttings are angular; they range in size from 2 to $8 \mathrm{~mm}$, and most are gray in color. These grains effervesce in hydrochloric acid, suggesting calcite, a common subsurface mineral. The highest concentrations of cuttings are localized at the drill sites and represent less than 1 percent of the total sample weight. The cuttings do not occur in a recognizable pile in the vicinity of the drill site in block 312 , according to R. A. Cooper, National Marine Fisheries Service (written commun., Oct. 14, 1983), who conducted visual and photographic surveys of the drill site from a submersible.

\section{TRACE METALS IN BULK SEDIMENTS}

During the first year of this program, we established that the concentrations of trace metals in sediments collected before drilling began were low compared to their average concentration in crustal rocks and that they are characteristic of uncontaminated coarse-grained sediments. We found the variability in trace-metal concentrations from station to station to be closely correlated with the content of fine-grained material and organic carbon in the sediments, as commonly occurs (Crecelius and others, 1975). $\mathrm{Pb}$ values higher than average crustal abundances were measured only at the location south of Martha's Vineyard, where fine-grained sediments are accumulating and where previous studies (Bothner and others, 1981) have suggested tetraethyl lead from gasoline as a source of the elevated $\mathrm{Pb}$ found in this area.

Throughout the first 2 years of monitoring, the concentrations of $\mathrm{Ba}$ in bulk sediments from the upstream control stations (transect I, stations 1-3) are fairly consistent with time (fig. 4, appendix table 4A). On the basis of these data, we judge that no increase in Ba has occurred at these stations. We found no increases in the concentration of other metals as a result of drilling at these upstream locations during the first or second year of monitoring.

In contrast, there were some measurable changes in the concentration of $\mathrm{Ba}$ in block 410 (stations 16,17, and 18, fig. 5). Drilling began in this block immediately after the first sampling cruise (M1) in July 1981 and continued (with some interruptions) until March 31, 1982. The mean current flow on this part of the Continental Shelf is to the west, although tidal and storm currents can reverse the mean flow (Butman and others, 1982a). Relative to the mean current flow, stations 17 and 18 are upstream and downstream of the rig position, respectively (fig. 5 ).

At station 16, located within $200 \mathrm{~m}$ of the drill rig in block 410, average $B a$ concentrations have increased by a factor of 5.9 above predrilling levels. $\mathrm{Ba}$ concentrations apparently increased steadily until cruise 6 (October 1983) and then decreased by the time of cruises 7 and 8 . Explaining a maximum Ba concentration as late as cruise 6 is difficult because drilling was completed before the fourth 


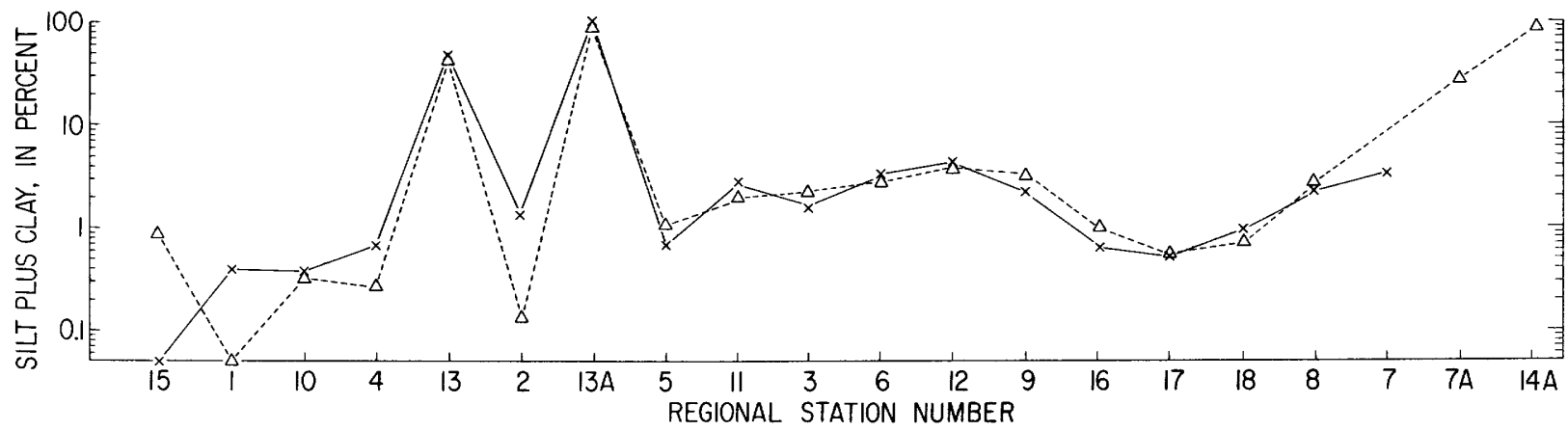

Figure 3.--Percent silt plus clay in samples collected at each regional station during years 1 (x) and 2 (triangle). Stations are listed in order of increasing water depth.

cruise. However, no statistical differences exist in the $\mathrm{Ba}$ concentration between cruise 4 and the remaining cruises at the 95-percent level of confidence $(a=0.05)$. The large standard deviation among the three replicate grab samples indicates that $\mathrm{Ba}$ is not distributed homogeneously over the sampling area. This heterogeneity is probably caused by the intermittent discharge of drilling fluids into a current field that changes direction of flow throughout the tidal cycle.

In agreement with the expected transport of drilling fluids to the west by the mean current flow, $\mathrm{Ba}$ concentrations were higher to the west than to

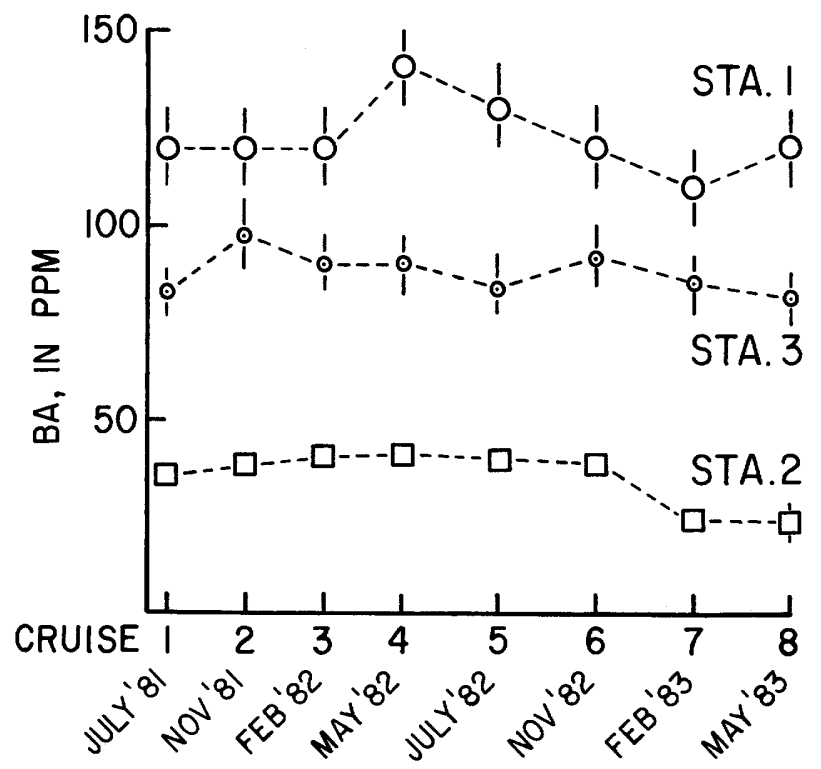

Figure 4.--Concentrations of barium in bulk sediment at upstream control stations on different sampling occasions. Drilling began after the first cruise and ended at all locations before the sixth cruise. Station locations are shown in figure $1 A$. the east. At station $18(2 \mathrm{~km}$ to the west of the drill rig), the maximum increase in $\mathrm{Ba}$ concentration was about a factor of 2 . At station $17(2 \mathrm{~km}$ to the east), the maximum increase was only about 1.3 times the background $\mathrm{Ba}$ concentration. At both locations, the $\mathrm{Ba}$ concentrations had decreased to predrilling levels by cruise 8 .

The concentration of $\mathrm{Cr}$ in these same samples (fig. 5) did not increase as a result of drilling even at the drill site. Similarly, we have observed no changes in the concentrations of other metals in the bulk sediments during this period of monitoring.

In block 312 (station 5), the location of the sitespecific survey, increases in $\mathrm{Ba}$ were observabie following the initiation of drilling on December 8 , 1981. Figure 6 shows the rate of increase at various locations around the drill site. The greatest increase (factor of 4.7 above background) was observed at the drill site. At stations more than $0.5 \mathrm{~km}$ from the drill site, slightly higher increases were observed to the west than to the east, which is consistent with the expected direction of transport. At all but station 5-10, the maximum concentration was observed during cruise 5 , which was conducted immediately after drilling was completed. At most stations, the concentrations decreased on subsequent sampling occasions.

The concentration of $\mathrm{Cr}$ (fig. 6) or of other metals in bulk sediments at block 312 did not increase as a result of drilling.

\section{TRACE METALS IN THE FINE FRACTION OF SEDIMENT}

Within the sediment fraction finer than $60 \mu \mathrm{m}$ (appendix table 4B), the Ba concentration increased dramatically at stations near the drill rig 

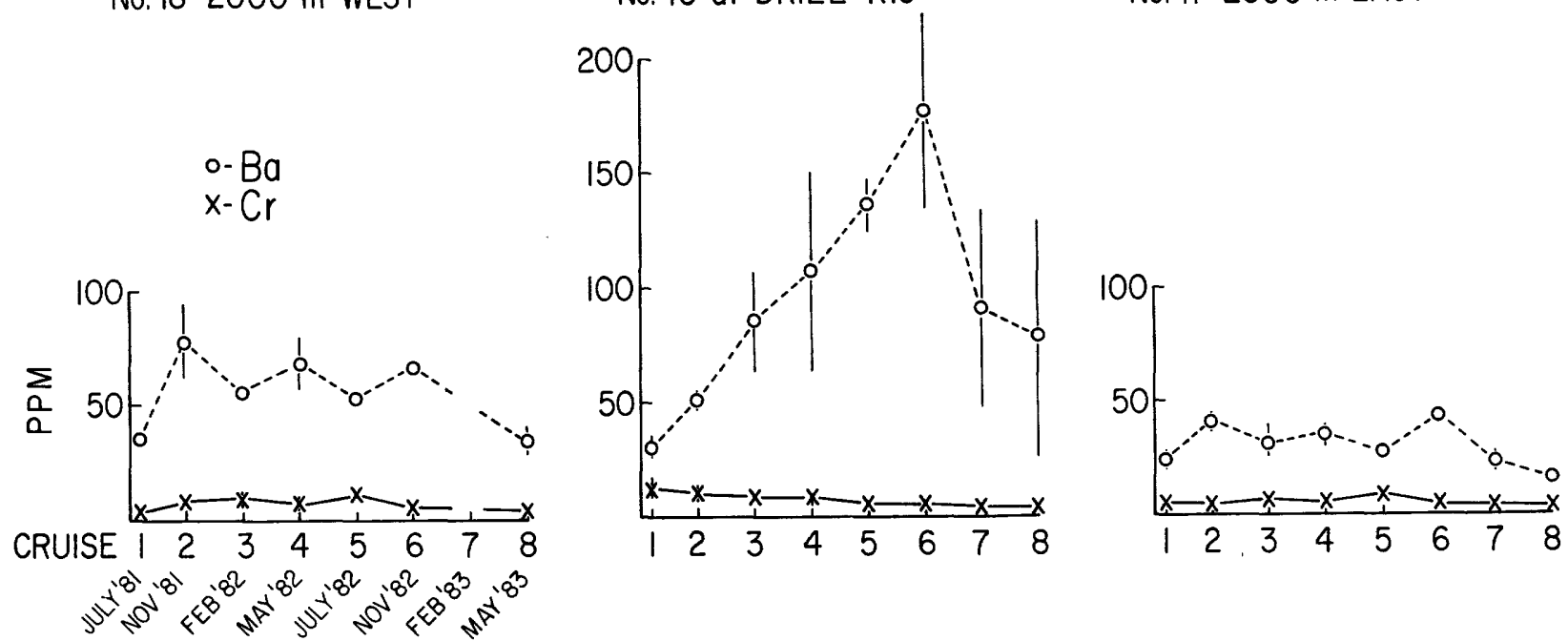

Figure 5.--Concentrations of barium (circle) and chromium ( $x$ ) in bulk sediment on different sampling occasions near the drill site at block 410. Drilling began after the first cruise and ended prior to the fourth cruise. Error bars are one standard deviation from three individual replicates.

at block 410 (fig. 7). At station 16, adjacent to the rig, the concentrations reached 8,000 to $10,000 \mathrm{ppm}$ by the third cruise and remained high through the seventh cruise. At station 17,2 km upstream of the drill rig, the $\mathrm{Ba}$ concentrations increased less than at station $18,2 \mathrm{~km}$ downstream of the drill rig. The upstream-downstream concept, which was fundamental to the design of the station array, also seems to be illustrated by these data.

At each of these three stations, the average concentration of $\mathrm{Ba}$ appears to have decreased at the time of the eighth cruise. However, the error bars about the mean of three field replicates suggest a large within-station variability caused by a patchy distribution of $\mathrm{Ba}$ in this area. Confirmation of the decrease and an estimate of the rate of decrease will be attempted during the ongoing third year of this program.

The concentration of $\mathrm{Cr}$ (fig. 7) increased slightly at station 16 in an apparent response to drilling, reached a maximum concentration of approximately 2 times background levels by the third cruise, and then decreased to background concentrations again. No increases in $\mathrm{Cr}$ concentration were observed at stations 17 or 18 . The concentration of $\mathrm{Al}, \mathrm{Cr}$, and $\mathrm{Hg}$ in the fine fraction at station 16 also increased and decreased with similar magnitude and timing, as did that of Cr. We did not identify systematic increases of these metals at any other station.
At block 312, the drilling began just after the second cruise and was completed just before the fifth cruise. The $\mathrm{Ba}$ concentrations in the fine fraction of sediment clearly increased after drilling began and, at most stations, apparently decreased after the drilling ended (fig. 8). Concentrations of $\mathrm{Cr}$ did not increase during the drilling period. The other metals showed no changes attributable to drilling.

The temporal change of $\mathrm{Ba}$ in the fine fraction at the site-specific survey suggests a westward transport of Ba-rich fine sediment during this monitoring period. At station 5-28, located farthest to the east (upstream), the Ba concentrations reach a lower maximum than at most other stations and nearly return to background by the eighth cruise. At station 5-2, located $0.5 \mathrm{~km}$ east of the drill rig, $\mathrm{Ba}$ reaches the highest maximum after the completion of drilling (cruises M4 and M5) and decreases at the time of cruises M6 and M8. Ba concentrations at station $5-29,6 \mathrm{~km}$ to the west, continued to increase after drilling was completed. This continued increase may be caused by the transport and deposition of Ba-rich fine sediment originally deposited closer to the rig.

These results suggest that $\mathrm{Ba}$ is being dispersed from the immediate vicinity of the drilling rigs. The increasing concentration of $\mathrm{Ba}$ in the fine fraction during the 2 years of monitoring at stations 8 and 12 (fig. 9) supports this conclusion. Station 8 

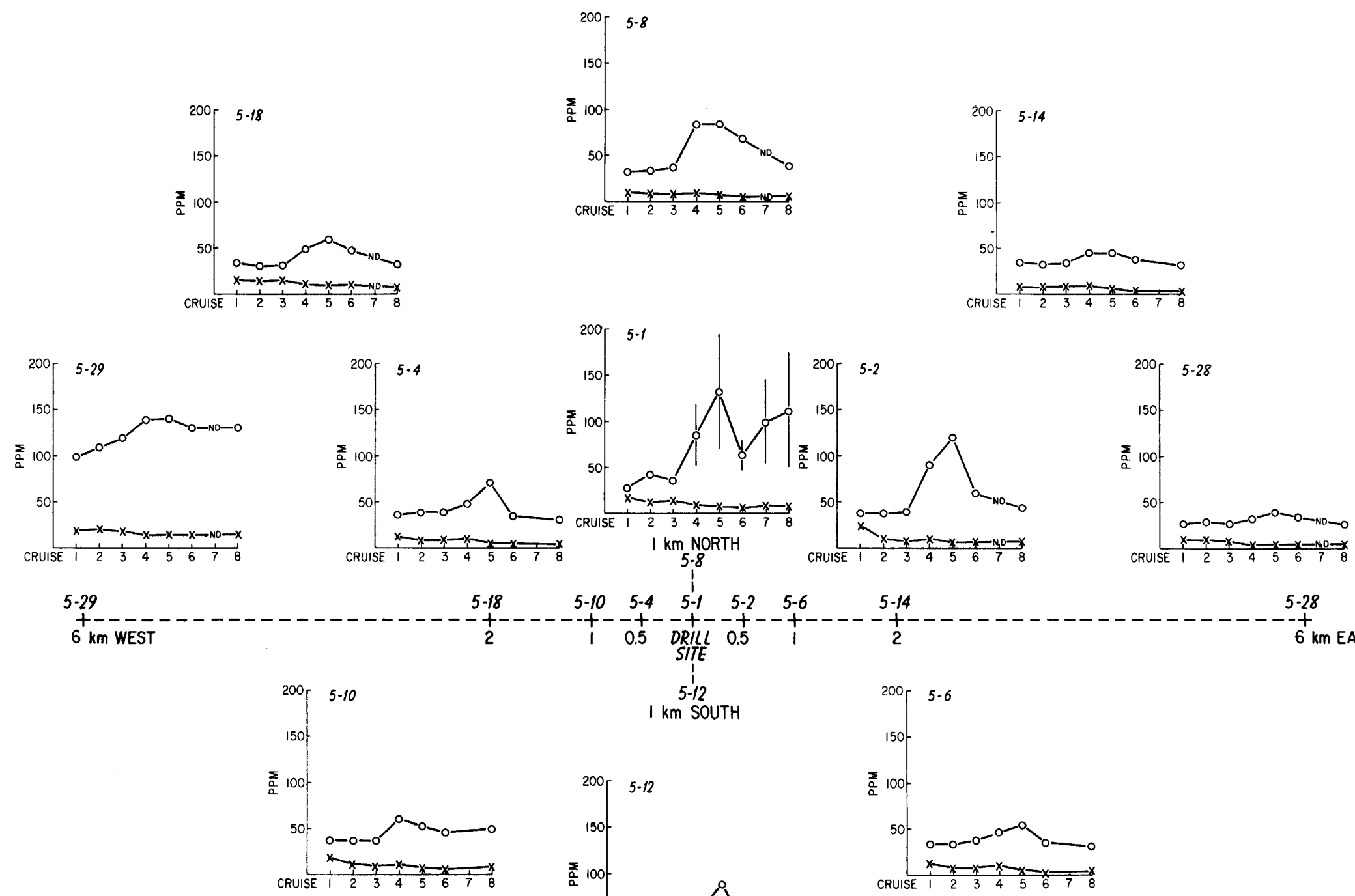

$\begin{array}{lllll}5-10 & 5-4 & 5-1 & 5-2 & 5-6\end{array}$
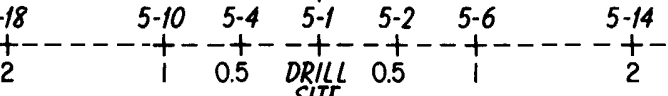

$5-14$
-+-
2
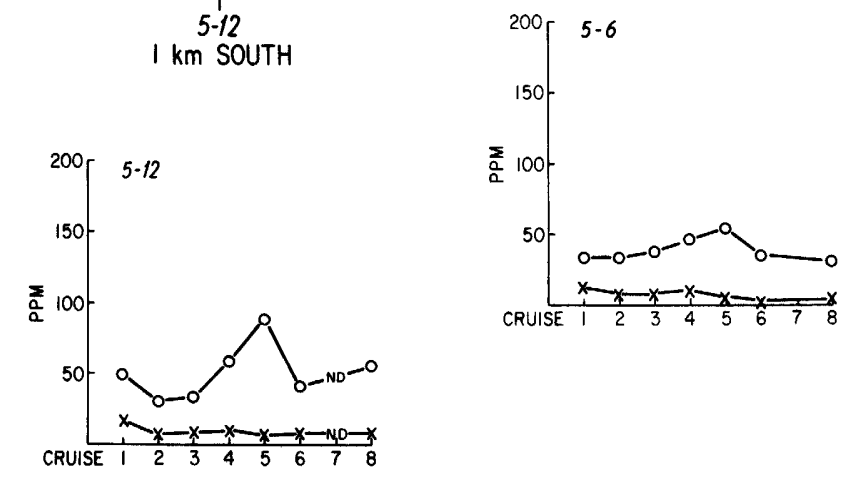

Figure 6.--Concentrations of barium (circle) and chromium ( $\mathrm{x}$ ) in bulk sediment on different sampling occasions near the drill site at block 312 . Stations are located on east- west and north-south transects through the drill site (see figure $1 \mathrm{~B}$ ). Drilling began after the second cruise and ended just before the fifth cruise. Error bars are one standard deviation among three individual replicates. ND= no data. 
is about $35 \mathrm{~km}$ to the west (downcurrent) of block 410 . Station $12,65 \mathrm{~km}$ to the west of block 312 , is the farthest station where a drilling-related Ba signal was measured.

\section{TRACE METALS IN DIFFERENT SIZE FRACTIONS OF SEDIMENT}

As a special study initiated during the second year of this program, we separated bulk sediment from Georges Bank into various grain-size classes with nylon sieves and analyzed the material in each size class for trace metals. We used this approach to determine how those trace metals (notably $\mathrm{Ba}$ ) whose concentrations are elevated by drilling are distributed within the sediment. This information may be useful in predicting the transport and dispersion of metals carried by various sediment-size classes.

Samples collected on the fourth cruise from the 0 - to $2-\mathrm{cm}$ interval at stations 16 and $5-2$ were selected because these samples showed relatively high concentrations of drilling-related metals. To determine the natural distribution of metals in different size classes, sediment was collected from control station 2 .

Figure 10 shows the distribution of sediment in weight percent among the various size classes for stations 16, 5-2, and 2. All three stations have similar modes and less than 1 percent silt plus clay.

The concentrations of $\mathrm{Ba}$ (fig. 11; appendix table $4 \mathrm{C}$ ) at the two drill sites (stations 16 and 5-2) do not differ from concentrations at the control site (station 2) for the sediment fractions coarser than $210 \mu \mathrm{m}$. Drilling muds do not contain any material coarser than about $105 \mu \mathrm{m}$, but drilling mud is known to adhere to drill cuttings, which are often greater than $1,000 \mu \mathrm{m}$ in size. The absence of high Ba levels at the drill sites in the fraction coarser than $210 \mu \mathrm{m}$ suggests that the drilling muds have been washed off the cuttings. This washing takes place either in the marine environment or during our size separation procedures in the laboratory.

At station 16, the Ba concentrations of the size classes finer than 105- $\mu \mathrm{m}$ (very fine sand) are more than 2 and as much as 10 times higher than at station 2. The highest concentration of $\mathrm{Ba}(4,150$ $\mathrm{ppm}$ ) at this station, and the largest factor of increase (factor of 10) compared to the control station, occurs in the 60- to $105-\mu \mathrm{m}$-size fraction. On the basis of the textural analyses of standard barite by the American Petroleum Institute, only about 4 percent of the barite used in well drilling is in the 60 - to $105-\mu \mathrm{m}$ fraction, and the remaining 96 percent is finer than $60 \mu \mathrm{m}$. The chemical data suggest that the coarsest fraction of the drilling muds in the sediments close to the rig is transported away from the rig more slowly than are the finer barite components. As natural processes winnow these sediments, we expect that $\mathrm{Ba}$ concentrations in the fractions finer than $60-\mu \mathrm{m}$ will decrease faster than the concentrations in the 105- to $60-\mu \mathrm{m}$ fraction. This size-separation technique applied to later samples from the same location may be useful in defining the relative transport rates of different textural sizes on Georges Bank.

At station 5-2, the maximum Ba concentration occurs in the 60 - to $30-\mu \mathrm{m}$ fraction, slightly finer than the observed maximum at station 16 . One reason for this difference may be that the well at station 5-2 was still active at the time of sampling, so natural winnowing processes had not yet removed the finer material. In contrast, the samples from station 16 were collected approximately 6 weeks after operations had ceased.

The effect of winnowing with time also may be illustrated with the plot of percent $\mathrm{Ba}$ in each size fraction (fig. 12). At station 16, in spite of the large increases in concentration of $\mathrm{Ba}$ in the fraction finer than $105 \mu \mathrm{m}$, the majority (greater than 70 percent) of the $\mathrm{Ba}$ in the sample is in the size classes coarser than $210 \mu \mathrm{m}$, which we interpret to be naturally occurring $\mathrm{Ba}$. At station 5-2, where drilling was active at the time of sampling, the majority (about 68 percent) of the $\mathrm{Ba}$ in the sample is in fractions finer than $210 \mu \mathrm{m}$.

Among the other metals analyzed in the sizeseparated samples ( $\mathrm{Al}, \mathrm{Cd}, \mathrm{Cr}, \mathrm{Cu}, \mathrm{Fe}, \mathrm{Mn}, \mathrm{Ni}, \mathrm{Pb}$, and $\mathrm{Zn}$ ), only $\mathrm{Al}$ and $\mathrm{Pb}$ concentrations in the finer fractions at the drill sites are slightly higher than those at the control station (fig. $13 A, B$ ). Concentrations of $\mathrm{Cu}$ (fig. $13 \mathrm{C}$ ) and the remaining metals are distributed similarly at all three stations. 


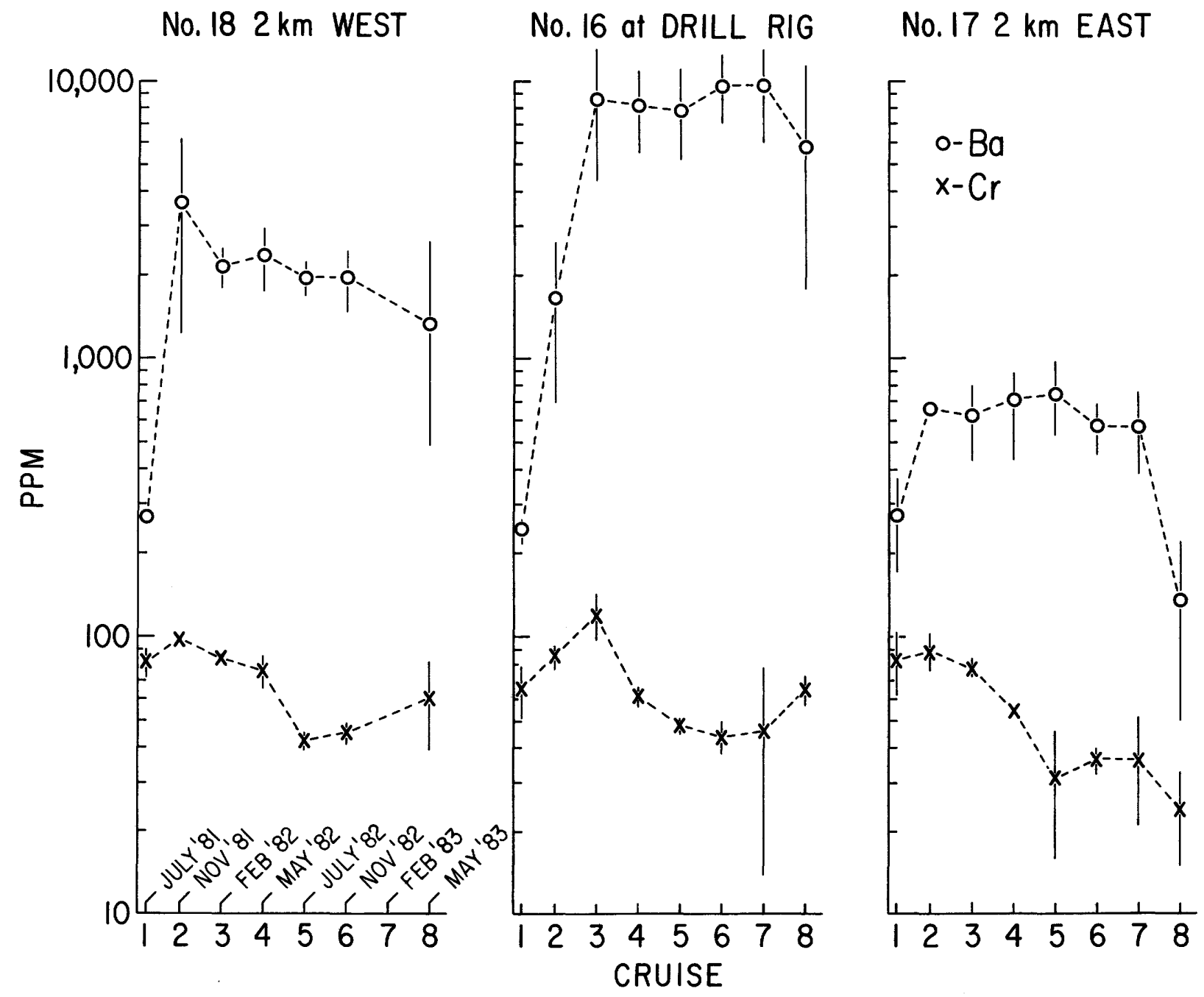

Figure 7.--Concentrations of barium (circle) and chromium $(x)$ in the fine fraction (less than $60 \mu \mathrm{m}$ ) on different sampling occasions near the drill site at block 410 . Drilling began after the first cruise and ended prior to the fourth cruise. Error bars are one standard deviation among three individual replicates.

\section{TRACE-METAL CONCENTRATIONS OF SEDIMENT-TRAP SAMPLES}

Sediment traps were deployed at various depths above the sea floor in the vicinity of block 312 and in Lydonia Canyon (appendix table 1C). The objective of this experiment was to measure the suspended components of drilling mud that are carried in the water column. This experiment was part of a USGS program designed to measure currents and sediment transport on the Continental Shelf and in the major submarine canyons that cut into the southern flank of Georges Bank (Butman and others, 1982b). Because of the shallow water depths and the high current energy on Georges Bank, the traps deployed in this experiment primarily collect sediments resuspended from the bottom. However, particles falling from surface waters (such as discharged drilling mud), biological material produced in the water column, and particles introduced from the atmosphere are also collected by the traps.

In the report for the first year of monitoring (Bothner and others, 1984), we listed the results of 


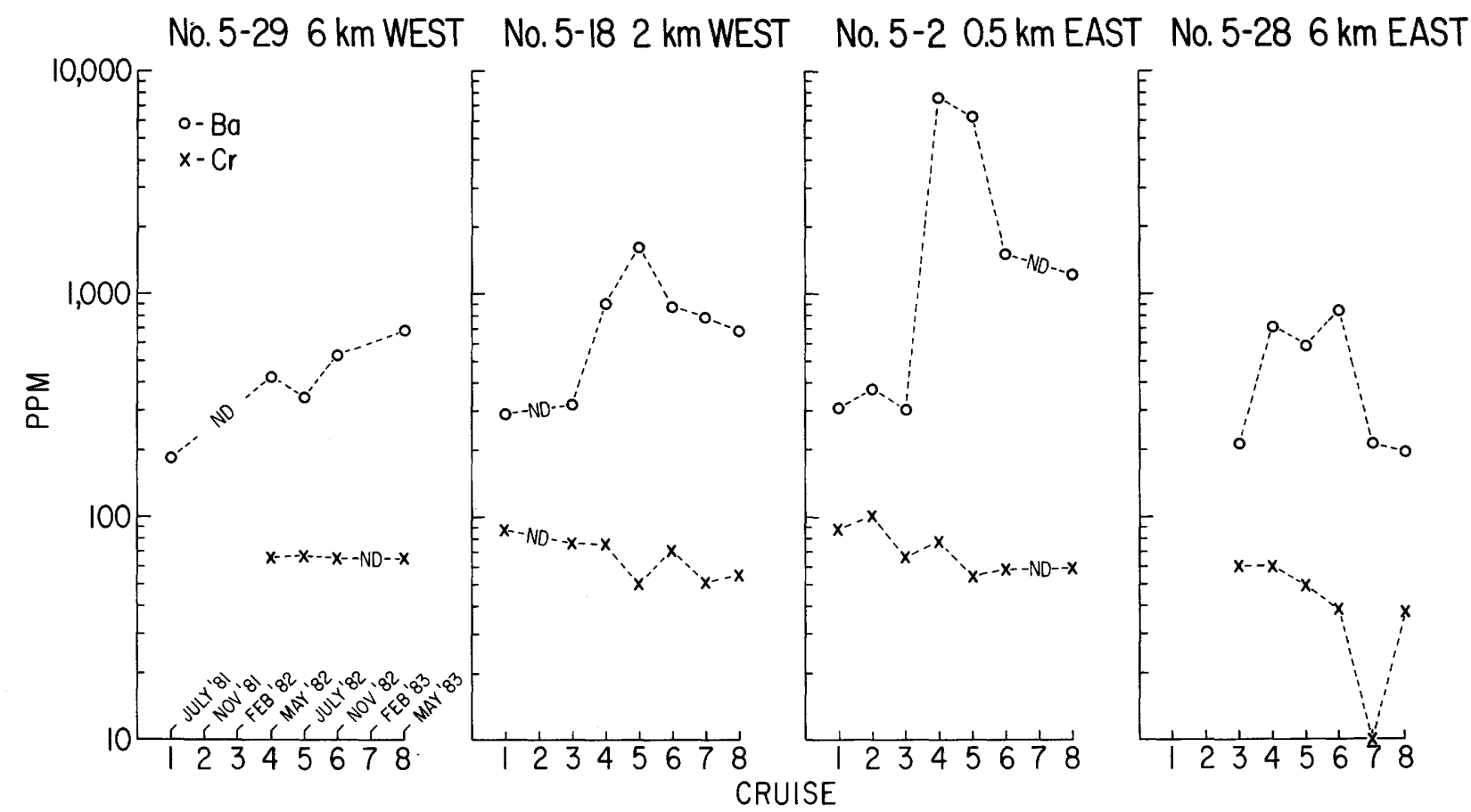

Figure 8.--Concentrations of barium (circle) and chromium ( $x$ ) in the fine fraction (less than $60 \mu \mathrm{m}$ ) on different sampling occasions near the drill site at block 312. Drilling began after the second cruise and ended just prior to the fifth cruise.

the analyses of sediment-trap samples that were collected on Georges Bank and in Lydonia Canyon before drilling began. The average metal concentrations and standard deviation are reported in table 4 for comparison to the metal concentrations in trap samples collected from the same areas while drilling was in progress. Textural analyses of the sediment-trap samples are reported in appendix table $3 \mathrm{C}$.

The metal concentrations in sediment-trap material collected at the head of Lydonia Canyon from April 1981 until November 1982 are generally within one standard deviation of the concentrations determined in predrilling trap samples. There is no systematic change in the concentration of metals between the four successive trap deployments during this time interval in Lydonia Canyon. Although predrilling and postdrilling $\mathrm{Ba}$ concentrations are not different in trap samples at this location, analyses of the sediment fraction finer than $60 \mu \mathrm{m}$ should be conducted to further test for transport of drilling mud to the canyon. We expect that some transport to this area has occurred, on the basis of Ba profiles with depth in sediments discussed in the next section, TraceMetal Variations with Depth in Sediment.

Among the trap samples from locations in the vicinity of block $312, \mathrm{Ba}$ is the only metal that has a higher concentration in postdrilling samples than in predrilling samples. The highest concentration of $\mathrm{Ba}(1,900 \mathrm{ppm})$ was measured in sediment trap ST424, which was positioned $1 \mathrm{~km}$ west of the drill rig in block 312 while drilling was underway. The sediment in this trap was collected in a long tube that was later sectioned into length intervals that represent different time intervals of the deployment. The last material to enter the trap was deposited at the top of the tube. The variation in $\mathrm{Ba}$ concentration from interval to interval suggests that the flux of $\mathrm{Ba}$ to these traps is not constant. A variable flux is expected because the discharge of $\mathrm{Ba}$ is not constant nor is the current field that transports the drilling mud during and after discharge.

The trap-sample material that was collected after drilling was completed at the drill site in block 312 and $1 \mathrm{~km}$ to the west of the drill site contained $\mathrm{Ba}$ concentrations 5 times higher than 


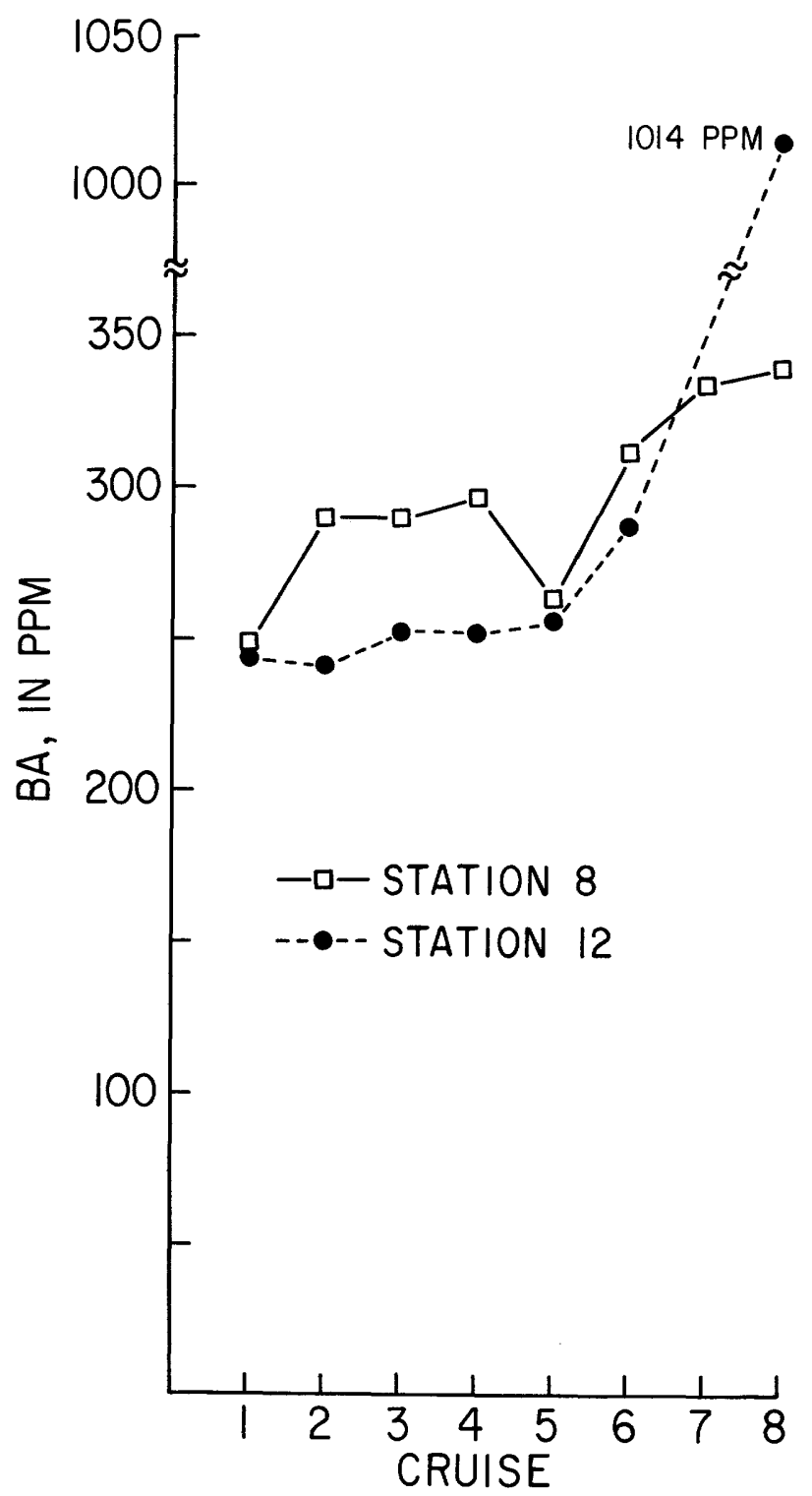

Figure 9.--Concentrations of barium in the fine fraction (less than $60 \mu \mathrm{m}$ ) on different sampling occasions at stations 8 and 12

the predrilling concentrations. The increase in concentration suggests that the barium sulfate deposited in the sediments is periodically resuspended to at least $25 \mathrm{~m}$ above the sea floor (the depth of our shallowest trap) and transported with the prevailing currents.

Sediment traps also were deployed $6 \mathrm{~km}$ east of the drilling rig in block 312 while drilling was in progress (ST426) and after completion of drilling in this block (ST513 and ST515). The Ba concentrations of these sediments are higher than those of predrilling samples but lower than samples collected to the west of or at the rig in block 312 during and after drilling. Some of the material contributing to the elevated $\mathrm{Ba}$ concentrations measured in these samples may have originated from the four drilling rigs operating between 5 and $45 \mathrm{~km}$ to the south or east of these trap locations. Alternatively, storm and tidal currents could have transported material eastward.

\section{TRACE-METAL VARIATIONS WITH DEPTH IN SEDIMENT}

During the second year of monitoring, sediment cores and grab samples (appendix table 1B) were subsampled as a function of sediment depth to evaluate the difference in metal concentrations between surficial and subsurface sediment. The surficial sediment (upper $1-2 \mathrm{~cm}$ ) represents the material most recently deposited or most affected by recent processes, whereas the deeper sediments, in general, were deposited in an earlier time period. The metal profiles with sediment depth indicate how deep the drilling mud has been mixed into the sediment by benthic organisms or currents. Textural parameters as a function of sediment depth are shown in appendix table 3B.

We analyzed five cores and five grab samples for the distribution of trace metals with sediment depth (sample locations and metal data presented in table 5). Ba was the only metal that had concentrations in the upper $2 \mathrm{~cm}$ of sediment at each station that were higher than those in the deeper sediment. This trend was observed in the analyses of both the bulk sediment and the fine fraction (fig. 14). The elevated $\mathrm{Ba}$ levels were observed only to a depth of $2 \mathrm{~cm}$ at station $5-1$. At least 85 percent of the drilling-related $\mathrm{Ba}$ (above background) was in the 0 - to 2 -cm sediment interval at station 16 (fig. 14). This finding supports our assumption that collection of the upper $2 \mathrm{~cm}$ of bottom sediment adequately samples the depth interval of sediment impacted by drilling muds at the present time. The gradients in $\mathrm{Ba}$ concentrations measured within the upper $2 \mathrm{~cm}$ in some of the cores suggest that, in the routine grab samples, the higher concentrations sometimes present in the 0 - to $1-\mathrm{cm}$ interval may be diluted with uncontaminated sediments in the $1-$ to $2-\mathrm{cm}$ interval. This potential dilution is accepted because the 0 - to $2-\mathrm{cm}$ interval is required to obtain sufficient material for analyses of trace metals (and hydrocarbons) from a single grab sample and 


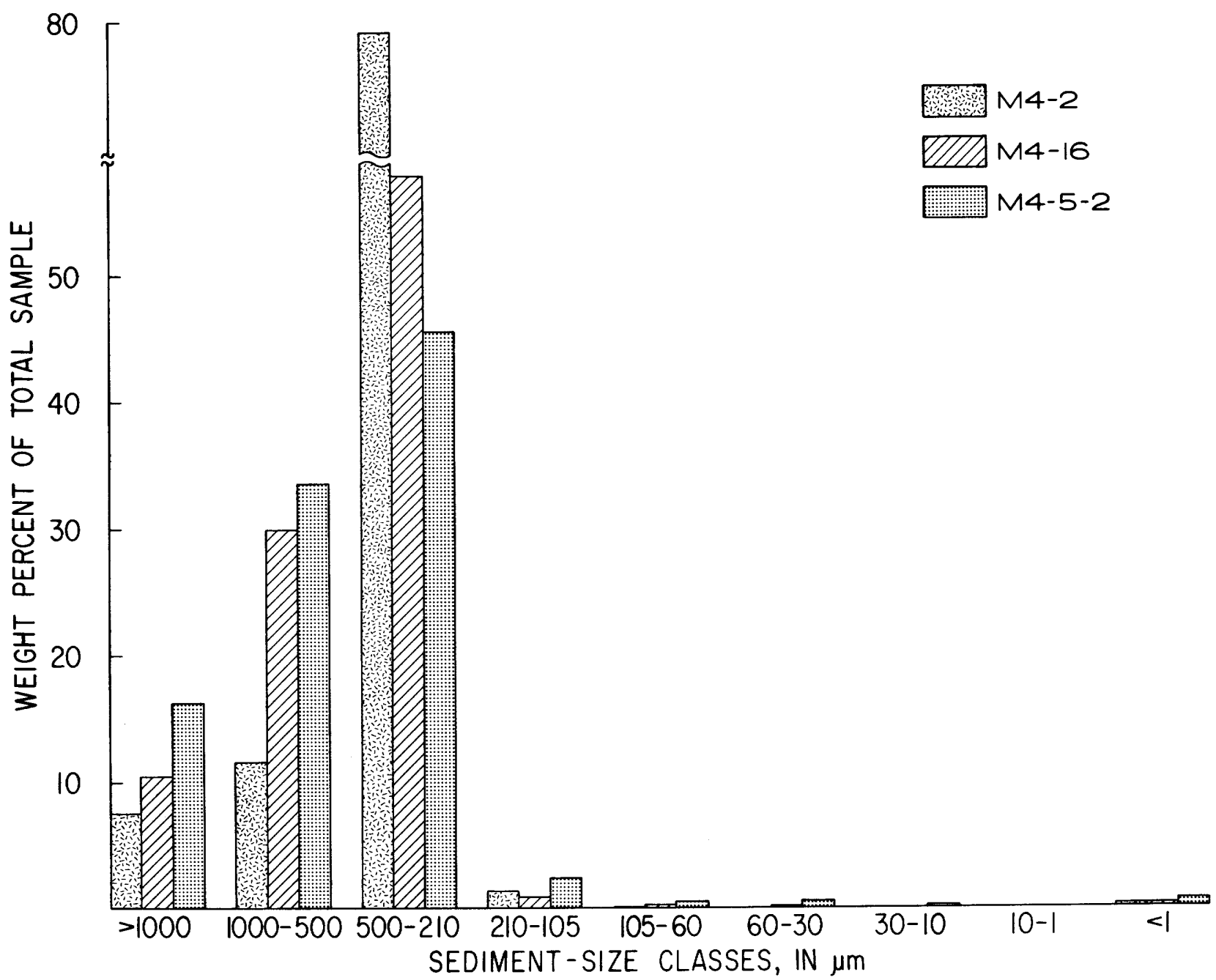

Figure 10.--Weight percent of sediment in different size fractions of bottom sediment collected on cruise 4 at control station 2 , regional station 16, and site-specific station 5-2 on Georges Bank.

because bioturbation and (or) physical mixing by currents may eventually mix a residual $\mathrm{Ba}$ signal deeper into the sediments. The rates of this mixing on Georges Bank are not well known, but they may be estimated by the distribution of $\mathrm{Ba}$ with sediment depth in cores collected at these locations in the future.

The concept of using metal profiles in sediments to evaluate a recent change in metal contributions to the sediments compared to deeper background concentrations was used to look for drilling-related $\mathrm{Ba}$ at new locations between transects II and III. Stations 19 (near the head of Oceanographer Canyon), 20, and 21 (fig. 1A) were sampled on cruise 9 to determine how far to the west beyond station 5-29 a Ba signal from drilling could be identified in the fine sediment fraction. A sample from the head of Lydonia Canyon collected on a USGS cruise also was included in this analysis.

At each of these locations, the Ba concentration in the fine fraction of surface sediment was higher than in the subsurface sediment (fig. 15 and table 5). The Ba enrichment in the $0-$ to $2-\mathrm{cm}$ horizon ranged from $14 \mathrm{ppm}$ to $265 \mathrm{ppm}$ higher than sediment at $6 \mathrm{~cm}$ and below. We interpret the consistent enrichment of $\mathrm{Ba}$ in surface sediments as evidence that the $\mathrm{Ba}$ concentration in the fine fraction has increased recently in response to drilling. Cores collected from the Mud Patch south of Martha's Vineyard and on the Continental Slope before drilling (M. H. Bothner, unpub. data, 1980) showed no Ba enrichment in the surface sediments. 


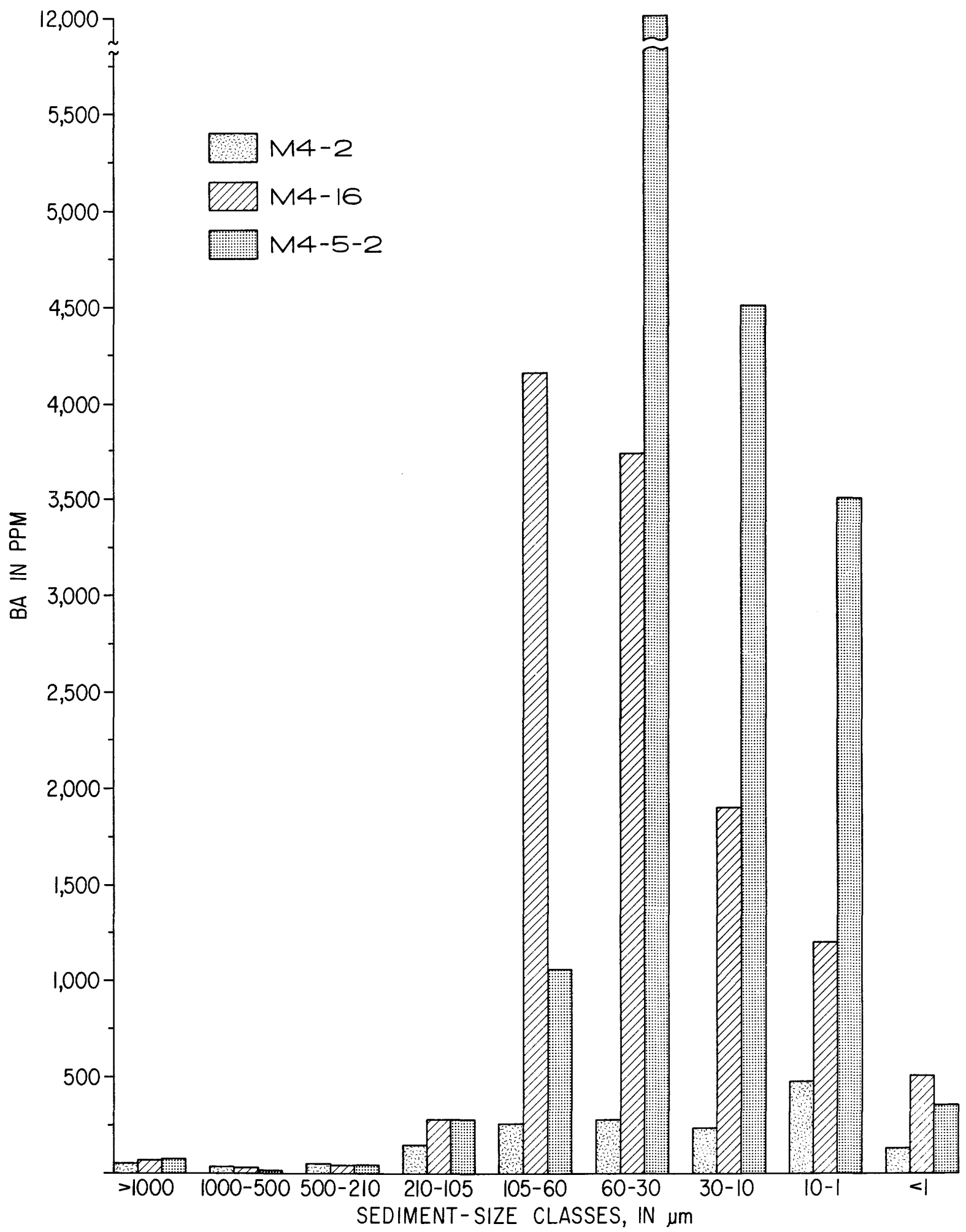

Figure 11.--Concentrations of barium in different size fractions of bottom sediments collected on cruise 4 at control station 2 , regional station 16, and site-specific station 5-2 on Georges Bank. 


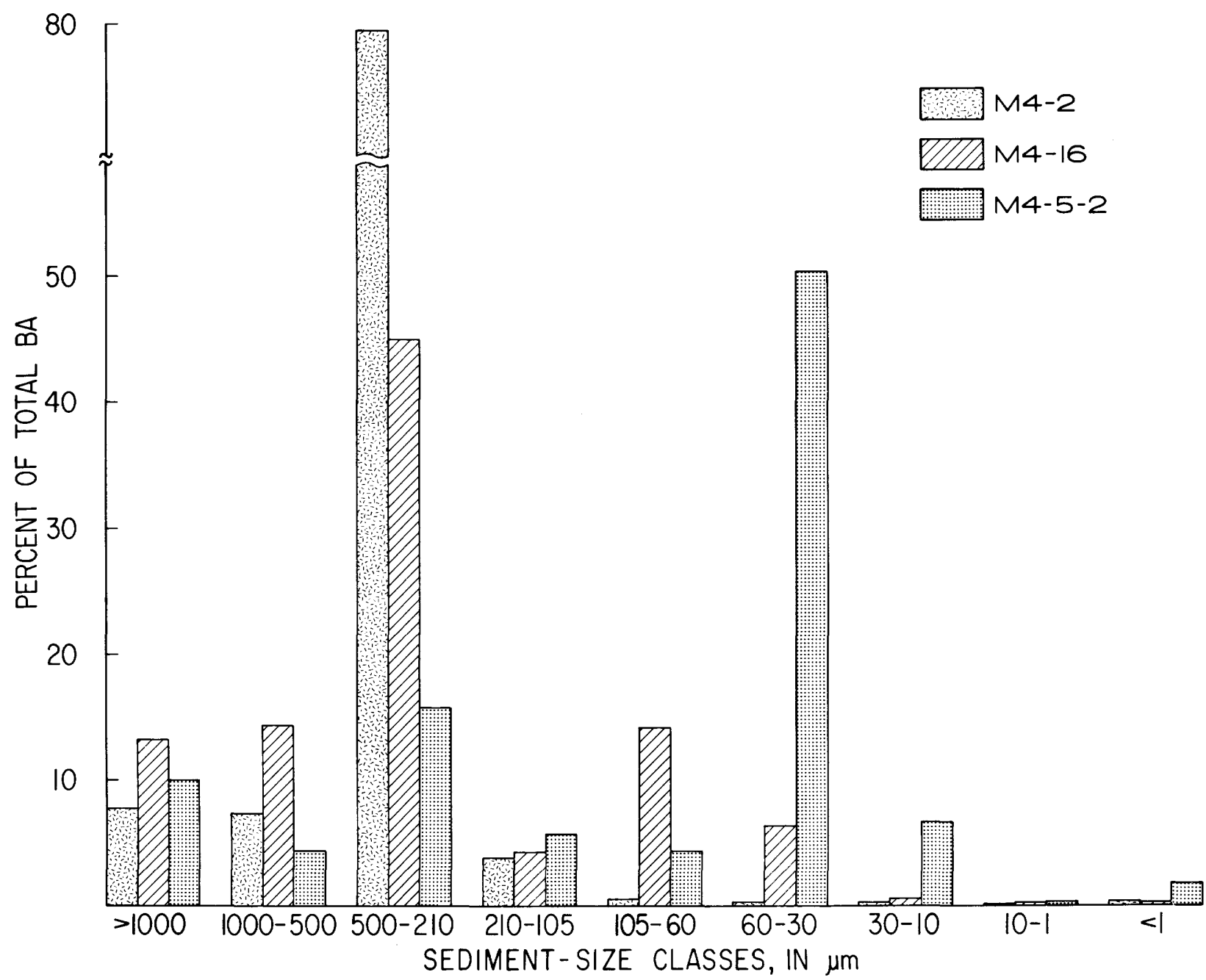

Figure 12.--Relative amount ( percent) of total barium in different size fractions of bottom sediments collected on cruise 4 at control station 2, regional station 16, and site-specific station 5-2 on Georges Bank.

This suggests that the Ba enrichment observed in the surface sediments of postdrilling samples is a result of drilling.

\section{BARIUM INVENTORY AND DECREASE AT BLOCK 312}

In the report for the first year of monitoring (Bothner and others, 1984), we estimated that approximately 18 percent of the barium sulfate discharged in block 312 up to the time of cruise 4 could be found in the sediment within $6 \mathrm{~km}$ of the rig. In the second year of this program, we were able to refine this estimate by using data from secondary stations and from new stations more than $6 \mathrm{~km}$ from the drilling activity at block 312 .

The total barium sulfate used in drilling the exploratory well at block 312 was $2,387,800 \mathrm{lb}$
(Danenberger, 1983). An estimated $630,000 \mathrm{lb}$ was left in the hole when the rig moved off location. If there were no losses of mud to porous subsurface rock formations while drilling, which is highly unlikely, then the total mud discharged to the ocean was $1,757,800 \mathrm{lb}$. This estimate is considered an upper limit because some loss to porous formations is expected. E. P. Danenberger (oral commun., September 21, 1983) estimated that, on the basis of drilling records, the maximum losses to porous formations would reduce the barite discharge to $800,000 \mathrm{lb}$. Danenberger suggested that the most likely range of barite discharge is between 1 million and 1.5 million pounds or between 42 percent and 63 percent of the total amount used.

The amount of drilling-related barium sulfate present in the sediments within the site-specific 

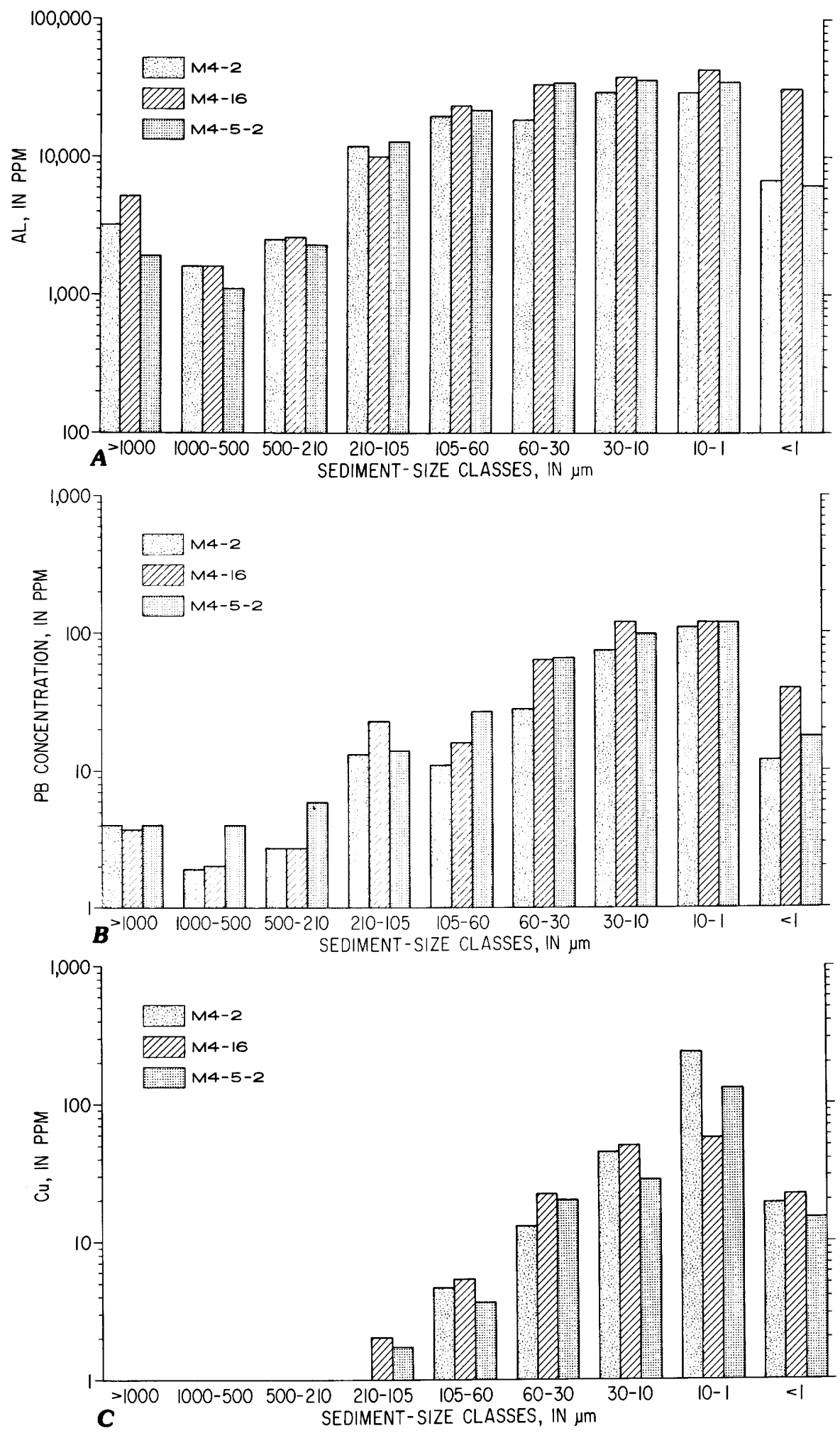

Figure 13A.--Concentrations of aluminum; B.--Concentrations of lead ; C. --Concentrations of copper in different size fractions of bottom sediments collected on cruise 4 at control station 2 , regional station 16 , and site-specific station 5-2 on Georges Bank. 
Table 4.--Chemical analyses of sediment-trap samples collected before and after drilling began (Bothner and others, 1982)

\begin{tabular}{|c|c|c|c|c|c|c|c|c|c|c|c|c|}
\hline \multicolumn{13}{|c|}{ Before drilling began } \\
\hline & $\begin{array}{c}\mathrm{Al} \\
\text { (percent) }\end{array}$ & $\begin{array}{c}\mathrm{Ba} \\
\text { (ppm) }\end{array}$ & $\begin{array}{c}\mathrm{Cd} \\
(\rho \mathrm{pm})\end{array}$ & $\begin{array}{c}\mathrm{Cr} \\
\text { (ppm) }\end{array}$ & $\begin{array}{c}\mathrm{Cu} \\
(\mathrm{ppm})\end{array}$ & $\begin{array}{c}\mathrm{Hg} \\
(\mathrm{ppm}) \\
\end{array}$ & $\begin{array}{c}\mathrm{Fe} \\
\text { (percent) }\end{array}$ & $\begin{array}{c}\mathrm{Mn} \\
(\mathrm{ppm}) \\
\end{array}$ & $\begin{array}{c}\mathrm{N1} \\
(\mathrm{ppm})\end{array}$ & $\begin{array}{c}\mathrm{Pb} \\
(\mathrm{ppm})\end{array}$ & $\begin{array}{c}\mathrm{V} \\
(\mathrm{ppm}) \\
\end{array}$ & $\begin{array}{c}\mathrm{Zn} \\
(\mathrm{ppm}) \\
\end{array}$ \\
\hline $\begin{array}{l}\text { Mean- } \\
\text { Stand. dev. of analyses- } \\
\text { No. }\end{array}$ & $\begin{array}{r}3.04 \\
-\quad .79 \\
--13\end{array}$ & $\begin{array}{r}225 \\
66 \\
13\end{array}$ & $\begin{array}{r}0.26 \\
.28\end{array}$ & $\begin{array}{l}71 \\
15 \\
13\end{array}$ & $\begin{array}{l}19 \\
10 \\
13\end{array}$ & $\begin{array}{r}0.044 \\
13\end{array}$ & $\begin{array}{r}1.94 \\
10^{.40}\end{array}$ & $\begin{array}{r}466 \\
130 \\
13\end{array}$ & $\begin{array}{l}39 \\
15 \\
13\end{array}$ & $\begin{array}{l}36 \\
10 \\
12\end{array}$ & $\begin{array}{l}82 \\
28 \\
13\end{array}$ & $\begin{array}{r}132 \\
124 \\
13\end{array}$ \\
\hline $\begin{array}{lc}\text { Field } & \text { Lab } \\
\text { number } & \text { number } \\
\text { Lydonia } & \text { Canyon: }\end{array}$ & $\begin{array}{c}\text { A1 } \\
\text { (percent) }\end{array}$ & $\begin{array}{c}\mathrm{Ba} \\
(\mathrm{ppm})\end{array}$ & $\begin{array}{c}\mathrm{Cd} \\
(\mathrm{ppm}) \\
\end{array}$ & $\begin{array}{c}\text { Cer dr } \\
\text { Cr } \\
(\mathrm{ppm})\end{array}$ & $\begin{array}{c}\text { Ing b } \\
\mathrm{Cu} \\
(\mathrm{ppm})\end{array}$ & $\begin{array}{c}\mathrm{gan} \\
\mathrm{Hg} \\
(\mathrm{ppm})\end{array}$ & $\begin{array}{c}\mathrm{Fe} \\
\text { (percent) }\end{array}$ & $\begin{array}{c}\mathrm{Mn} \\
(\mathrm{ppm}) \\
\end{array}$ & $\begin{array}{c}\mathrm{Ni} \\
(\mathrm{ppm}) \\
\end{array}$ & $\begin{array}{c}\mathrm{Pb} \\
(\mathrm{ppm}) \\
\end{array}$ & $\begin{array}{c}v \\
(\mathrm{ppm})\end{array}$ & $\begin{array}{c}\mathrm{Zn} \\
(\mathrm{ppm})\end{array}$ \\
\hline $\begin{array}{l}\text { Lydonia Canyon: } \\
\text { drili1ng in progress }\end{array}$ & & & & & & & & & & & & \\
\hline $\begin{array}{l}\text { ST222-0-15 } 1---W-221248 \\
\text { ST301-0-4----W-221249 } \\
\text { ST403-0-20----W-221285 } \\
\text { ST536-0-2-----W-221271 }\end{array}$ & $\begin{array}{l}3.91 \\
3.78 \\
3.20 \\
3.54\end{array}$ & $\begin{array}{l}304.2 \\
266.5 \\
260.0 \\
274.2\end{array}$ & $\begin{array}{l}0.08 \\
.05 \\
.09 \\
.16\end{array}$ & $\begin{array}{l}52.1 \\
47.7 \\
40.0 \\
45.7\end{array}$ & $\begin{array}{l}10.9 \\
17.8 \\
14.0 \\
16.0\end{array}$ & $\begin{array}{l}0.05 \\
.04 \\
.03 \\
.03\end{array}$ & $\begin{array}{l}2.50 \\
2.33 \\
1.90 \\
2.06\end{array}$ & $\begin{array}{l}348 \\
444 \\
240 \\
366\end{array}$ & $\begin{array}{l}31.5 \\
27.8 \\
18.0 \\
17.1\end{array}$ & $\begin{array}{l}32.6 \\
33.3 \\
26.0 \\
28.6\end{array}$ & $\begin{array}{l}66.3 \\
53.3 \\
44.0 \\
41.1\end{array}$ & $\begin{array}{l}65.2 \\
64.4 \\
46.0 \\
62.8\end{array}$ \\
\hline \multicolumn{13}{|l|}{$\begin{array}{l}1 \mathrm{~km} \text { west of rig: } \\
\text { drililng in progress }\end{array}$} \\
\hline $\begin{array}{l}\text { ST424-0-4----W-221251 } \\
\text { ST424-4-7----W-221252 } \\
\text { ST424-7-10----W-221253 } \\
\text { ST424-10-15---W-221254 } \\
\text { ST424-15-17---W-221255 } \\
\text { ST424-17-20.5-W-221256 }\end{array}$ & $\begin{array}{l}2.73 \\
2.52 \\
2.98 \\
3.11 \\
3.34 \\
3.40\end{array}$ & $\begin{array}{r}1783.6 \\
1889.1 \\
1152.9 \\
771.8 \\
1224.5 \\
551.7\end{array}$ & $\begin{array}{l}.39 \\
.38 \\
.45 \\
.18 \\
.17 \\
.22\end{array}$ & $\begin{array}{l}40.4 \\
37.8 \\
40.9 \\
40.3 \\
44.5 \\
51.7\end{array}$ & $\begin{array}{r}11.7 \\
8.9 \\
9.4 \\
11.1 \\
13.6 \\
16.4\end{array}$ & $\begin{array}{l}.04 \\
.03 \\
.04 \\
.03 \\
.03 \\
.03\end{array}$ & $\begin{array}{l}2.14 \\
2.14 \\
2.36 \\
2.30 \\
2.60 \\
2.70\end{array}$ & $\begin{array}{l}345 \\
290 \\
310 \\
357 \\
445 \\
481\end{array}$ & $\begin{array}{l}14.3 \\
12.6 \\
16.1 \\
12.7 \\
18.6 \\
17.6\end{array}$ & $\begin{array}{l}34.5 \\
30.2 \\
27.3 \\
30.0 \\
39.6 \\
64.6\end{array}$ & $\begin{array}{l}42.8 \\
45.3 \\
54.5 \\
55.3 \\
59.4 \\
69.3\end{array}$ & $\begin{array}{l}89.2 \\
74.3 \\
62.0 \\
57.6 \\
73.0 \\
89.2\end{array}$ \\
\hline \multicolumn{13}{|l|}{$\begin{array}{l}6 \mathrm{~km} \text { east of rig: } \\
\text { dril1ing in progress }\end{array}$} \\
\hline $\begin{array}{l}\text { ST426-0-4-----W-221257 } \\
\text { ST426-6-8-----W-221258 } \\
\text { ST426-12.5-15-W-221259 }\end{array}$ & $\begin{array}{l}2.24 \\
3.09 \\
3.07\end{array}$ & $\begin{array}{l}407.0 \\
482.4 \\
378.1\end{array}$ & $\begin{array}{l}.51 \\
.35 \\
.45\end{array}$ & $\begin{array}{l}27.5 \\
44.5 \\
40.2\end{array}$ & $\begin{array}{l}10.2 \\
11.1 \\
11.8\end{array}$ & $\begin{array}{l}.02 \\
.04 \\
.03\end{array}$ & $\begin{array}{l}1.73 \\
2.47 \\
2.48\end{array}$ & $\begin{array}{l}275 \\
346 \\
449\end{array}$ & $\begin{array}{l}11.2 \\
13.6 \\
15.4\end{array}$ & $\begin{array}{l}25.4 \\
30.9 \\
36.6\end{array}$ & $\begin{array}{l}34.6 \\
56.9 \\
59.1\end{array}$ & $\begin{array}{r}76.3 \\
56.9 \\
100.4\end{array}$ \\
\hline \multicolumn{13}{|l|}{$\begin{array}{l}\text { Rig site: } \\
\text { postdriling }\end{array}$} \\
\hline $\begin{array}{l}\text { ST501C-W }{ }^{2}----W-221260 \\
\text { ST502-0-4----W-221261 } \\
\text { ST502-4-8-----W-221262 } \\
\text { ST502-8-12----W-221263 } \\
\text { ST502-12-14---W-221264 } \\
\text { ST505C-W------W-221265 }\end{array}$ & $\begin{array}{l}2.96 \\
3.24 \\
3.48 \\
3.42 \\
3.18 \\
3.49\end{array}$ & $\begin{array}{r}1023.5 \\
802.7 \\
721.7 \\
756.7 \\
1070.5 \\
1070.9\end{array}$ & $\begin{array}{r}1.08 \\
.30 \\
.55 \\
.41 \\
.42 \\
.14\end{array}$ & $\begin{array}{l}24.2 \\
44.0 \\
43.8 \\
43.9 \\
40.0 \\
49.8\end{array}$ & $\begin{array}{l}24.2 \\
23.3 \\
20.6 \\
19.5 \\
14.1 \\
18.7\end{array}$ & $\begin{array}{l}.04 \\
.05 \\
.10 \\
.07 \\
.04 \\
.03\end{array}$ & $\begin{array}{l}2.10 \\
2.46 \\
2.58 \\
2.56 \\
2.35 \\
2.61\end{array}$ & $\begin{array}{l}253 \\
867 \\
760 \\
622 \\
459 \\
237\end{array}$ & $\begin{array}{r}5.4 \\
24.6 \\
23.2 \\
22.0 \\
15.3 \\
27.4\end{array}$ & $\begin{array}{l}18.3 \\
46.6 \\
46.4 \\
43.9 \\
31.8 \\
43.6\end{array}$ & $\begin{array}{r}5.4 \\
62.1 \\
61.9 \\
61.0 \\
56.5 \\
71.0\end{array}$ & $\begin{array}{r}121.2 \\
79.0 \\
86.3 \\
74.5 \\
69.4 \\
72.2\end{array}$ \\
\hline \multicolumn{13}{|l|}{$\frac{1 \mathrm{~km} \text { west of rig: }}{\text { postdrilling }}$} \\
\hline $\begin{array}{l}\text { ST506C-W------W-221266 } \\
\text { ST508C-W------W-221267 } \\
\text { ST510C-W-----W-221268 }\end{array}$ & $\begin{array}{l}2.30 \\
3.47 \\
1.98\end{array}$ & $\begin{array}{r}767.4 \\
1165.3 \\
796.0\end{array}$ & $\begin{array}{l}.73 \\
.21 \\
.03\end{array}$ & $\begin{array}{l}26.9 \\
48.3 \\
26.1\end{array}$ & $\begin{array}{l}13.6 \\
19.8 \\
10.4\end{array}$ & $\begin{array}{l}.03 \\
.04 \\
.02\end{array}$ & $\begin{array}{l}1.71 \\
2.60 \\
1.46\end{array}$ & $\begin{array}{l}230 \\
198 \\
250\end{array}$ & $\begin{array}{r}3.8 \\
24.8 \\
10.4\end{array}$ & $\begin{array}{l}30.7 \\
44.6 \\
26.1\end{array}$ & $\begin{array}{l}11.5 \\
64.5 \\
23.0\end{array}$ & $\begin{array}{r}211.0 \\
74.4 \\
55.3\end{array}$ \\
\hline \multicolumn{13}{|l|}{$\frac{6 \mathrm{~km} \text { east of rig: }}{\text { postdrilling }}$} \\
\hline $\begin{array}{l}\text { ST513C-W----W-221269 } \\
\text { ST515C-W----W-221270 }\end{array}$ & $\begin{array}{l}3.28 \\
3.28\end{array}$ & $\begin{array}{l}625.8 \\
702.0\end{array}$ & $\begin{array}{l}.14 \\
.11\end{array}$ & $\begin{array}{l}43.2 \\
45.2\end{array}$ & $\begin{array}{l}12.4 \\
15.8\end{array}$ & $\begin{array}{l}.04 \\
.03\end{array}$ & $\begin{array}{l}2.38 \\
2.37\end{array}$ & $\begin{array}{l}328 \\
226\end{array}$ & $\begin{array}{l}11.2 \\
21.5\end{array}$ & $\begin{array}{l}37.2 \\
33.9\end{array}$ & $\begin{array}{l}41.7 \\
66.7\end{array}$ & $\begin{array}{l}76.0 \\
79.2\end{array}$ \\
\hline
\end{tabular}

1 Depth interval (cm) in sediment-trap sample.
2 W=whole sediment trap homogenized before analysis.

survey at the completion of the exploratory well was estimated by computing the increase in $\mathrm{Ba}$ concentrations at each of the 29 stations (fig. 16) between cruise 5 , conducted 4 weeks after completion of drilling, and cruise 1 . Ba increases at each radial distance from the drill site were averaged (fig. 17) and used to estimate a representative concentration increase for each annulus around the drill site. We assume that the increased $\mathrm{Ba}$ is contained within the sampling depth interval of 0 to $2 \mathrm{~cm}$. We judge this assumption to be valid, on the basis of the metal profiles described elsewhere in this report (see p. 18 and fig. 14).

The inventory of barite is calculated from the field data with the following relation:

$$
\text { Total }=\Sigma A \cdot d \cdot Z \cdot C n \cdot\left(\mathrm{BaSO}_{4}\right) /(0.85 \cdot \mathrm{Ba})
$$

where $A=$ area of each annulus, $d=$ bulk density of dry sediment $(1.6 \mathrm{~g} / \mathrm{cc}), Z=$ depth interval $(0-2 \mathrm{~cm})$, $C n=$ net concentration increase of $\mathrm{Ba}$, and 
Table 5.--Chemical analyses of core samples and grab samples subsectioned into sequential depth intervals

[Depth interval, in $\mathrm{cm}$, is given at end of field number]

\begin{tabular}{|c|c|c|c|c|c|c|c|c|c|c|c|c|c|}
\hline $\begin{array}{c}\text { Field } \\
\text { no. }\end{array}$ & $\begin{array}{l}\text { Lab } \\
\text { no. }\end{array}$ & $\begin{array}{c}\mathrm{Al} \\
\text { (percent) }\end{array}$ & $\begin{array}{c}\mathrm{Ba} \\
)(\mathrm{ppm}) \\
\end{array}$ & $\begin{array}{c}\mathbf{C d} \\
(\mathrm{ppm})\end{array}$ & $\begin{array}{c}\mathrm{Cr} \\
(\mathrm{ppm})\end{array}$ & $\begin{array}{c}\mathrm{Cu} \\
(\mathrm{ppm}) \\
\end{array}$ & $\begin{array}{c}\mathrm{Fe} \\
\text { (percent) } \\
\end{array}$ & $\begin{array}{c}\mathrm{Hg} \\
(\mathrm{ppm}) \\
\end{array}$ & $\begin{array}{c}\mathrm{Mn} \\
(\mathrm{ppm}) \\
\end{array}$ & $\begin{array}{c}\mathrm{Ni} \\
(\mathrm{ppm})\end{array}$ & $\begin{array}{c}\mathrm{Pb} \\
(\mathrm{ppm}) \\
\end{array}$ & $\begin{array}{c}\mathrm{V} \\
(\mathrm{ppm})\end{array}$ & $\begin{array}{c}\mathrm{Zn} \\
(\mathrm{ppm}) \\
\end{array}$ \\
\hline \multicolumn{14}{|l|}{ Station 5-1 } \\
\hline $0 \mathrm{C122-64-01}$ & $\mathrm{W}-220589$ & 0.24 & 180.0 & $<0.02$ & 5.3 & $<1.0$ & 0.39 & -- & 340 & $<2.0$ & 5.3 & 11.0 & 6.6 \\
\hline $0 \mathrm{C} 122-64-02$ & W-220590 & .22 & 43.0 & .03 & 4.5 & $<1.0$ & .37 & - & 240 & $<2.0$ & 4.5 & 9.5 & 4.4 \\
\hline $0 C 122-64-03$ & W-220591 & .21 & 32.0 & $<.02$ & 4.8 & $<1.0$ & .37 & - & 200 & $<2.0$ & 4.5 & 10.0 & 4.4 \\
\hline $0 \mathrm{C} 122-64-04$ & W-220592 & .23 & 37.0 & $<.02$ & 5.0 & $<1.0$ & .38 & - & 200 & $<2.0$ & 4.2 & 11.0 & 4.4 \\
\hline $0 \mathrm{c} 122-64-05$ & W-220593 & .26 & 36.0 & $<.02$ & 5.3 & $<1.0$ & .47 & -- & 420 & $<2.0$ & 5.0 & 14.0 & 5.8 \\
\hline $0 \mathrm{C122-64-06}$ & W-220594 & .29 & 57.0 & $<.02$ & 5.5 & $<1.0$ & .54 & - & 790 & $<2.0$ & 5.9 & 17.0 & 6.6 \\
\hline $0 \mathrm{C} 122-64-10$ & W-220595 & .19 & 22.0 & .03 & 5.5 & $<1.0$ & .49 & -- & 200 & $<2.0$ & 4.3 & 15.0 & 4.4 \\
\hline $0 \mathrm{Cl} 22-64-20$ & $W-220596$ & .22 & 41.0 & $<.02$ & 4.5 & $<1.0$ & .62 & -- & 400 & $<2.0$ & 3.4 & 19.0 & 4.4 \\
\hline Station 5-1 (fine & fraction) & & & & & & & & & & & & \\
\hline $0 \mathrm{C} 122-64 \times 0-1$ & $\mathrm{~W}-222018$ & 3.34 & 7030.5 & .51 & 59.6 & 17.9 & 2.62 & .06 & 2026 & 32.2 & 51.2 & 71.5 & 143.0 \\
\hline $0 \mathrm{C} 122-64 \times 1-2$ & W-222019 & 3.92 & 3528.8 & .20 & 65.3 & 28.8 & 3.27 & .06 & 1830 & 32.7 & 35.3 & 70.6 & 95.4 \\
\hline $0 \mathrm{C} 122-64 \times 2-3$ & $\mathrm{~W}-222020$ & 4.15 & 1070.9 & .19 & 62.9 & 24.1 & 3.48 & .07 & 1606 & 34.8 & 34.8 & 75.0 & 81.7 \\
\hline $0 \mathrm{C} 122-64 \times 3-4$ & W-222021 & 3.95 & 844.2 & .18 & 59.9 & 24.5 & 3.27 & .04 & 2315 & 40.8 & 44.9 & 83.1 & 83.1 \\
\hline $0 \mathrm{c} 122-64 \times 4-5$ & $\mathrm{~W}-222022$ & 4.26 & 727.1 & .21 & 60.2 & 23.8 & 3.51 & .05 & 3134 & 50.1 & 60.2 & 86.5 & 116.6 \\
\hline $0 \mathrm{C} 122-64 \times 9-10$ & $\mathrm{~W}-222023$ & 3.13 & 434.5 & .17 & 36.5 & 29.5 & 3.65 & .09 & 7646 & 64.3 & 73.0 & 93.8 & 93.8 \\
\hline \multicolumn{14}{|l|}{ Station 5-4 } \\
\hline $0 \mathrm{C122-62-01}$ & W-220573 & .31 & 70.0 & $<.02$ & 7.0 & $<1.0$ & .40 & - & 200 & $<2.0$ & 4.8 & 9.5 & 5.8 \\
\hline $0 \mathrm{C} 122-62-02$ & W-220574 & .24 & 47.0 & $<.02$ & 6.0 & $<1.0$ & .35 & -- & 180 & $<2.0$ & 4.5 & 9.5 & 4.4 \\
\hline $0 C 122-62-03$ & W-220575 & .22 & 42.0 & .07 & 6.5 & $<1.0$ & .35 & -- & 140 & $<2.0$ & 4.0 & 10.0 & 5.0 \\
\hline $0 \mathrm{C122}-62-04$ & W-220576 & .22 & 38.0 & .05 & 6.0 & 1.9 & .41 & -- & 260 & $<2.0$ & 4.8 & 13.0 & 4.4 \\
\hline $0 \mathrm{C} 122-62-05$ & W-220577 & .21 & 30.0 & .32 & 5.5 & $<1.0$ & .35 & -- & 150 & $<2.0$ & 3.3 & 9.5 & 5.0 \\
\hline $00122-62-06$ & W-220578 & .21 & 31.0 & $<.02$ & 6.0 & $<1.0$ & .37 & -- & 190 & $<2.0$ & 3.8 & 10.0 & 5.8 \\
\hline $0 \mathrm{Cl} 22-62-10$ & W-220579 & .25 & 31.0 & $<.02$ & 7.0 & $<1.0$ & .40 & -- & 130 & $<2.0$ & 4.8 & 10.0 & 5.0 \\
\hline $0 C 122-62-15$ & W-220580 & .20 & 25.0 & .07 & 6.5 & $<1.0$ & .40 & - & 120 & $<2.0$ & 5.5 & 9.5 & 4.4 \\
\hline \multicolumn{14}{|l|}{ Station 5-10 } \\
\hline $00122-63-01$ & W-220581 & .35 & 55.0 & .03 & 7.3 & $<1.0$ & .43 & -- & 280 & $<2.0$ & 6.5 & 12.0 & 6.6 \\
\hline $0 \mathrm{C} 122-63-02$ & W-220582 & .25 & 39.0 & $<.02$ & 7.0 & $<1.0$ & .39 & -- & 290 & $<2.0$ & 5.3 & 11.0 & 4.4 \\
\hline $0 \mathrm{C} 122-63-03$ & W-220583 & .24 & 35.0 & $<.02$ & 7.0 & $<1.0$ & .43 & -- & 280 & $<2.0$ & 5.5 & 13.0 & 4.4 \\
\hline $0 \mathrm{C} 122-63-04$ & W-220584 & .22 & 31.0 & $<.02$ & 8.0 & $<1.0$ & .40 & - & 210 & $<2.0$ & 5.1 & 13.0 & 4.4 \\
\hline $0 \mathrm{C} 122-63-05$ & W-220585 & .23 & 32.0 & $<.02$ & 7.3 & $<1.0$ & .38 & -- & 180 & $<2.0$ & 5.3 & 12.0 & 4.4 \\
\hline $0 \mathrm{c} 122-63-06$ & W-220586 & .24 & 30.0 & $<.02$ & 7.8 & $<1.0$ & .40 & -- & 160 & $<2.0$ & 5.9 & 12.0 & 5.0 \\
\hline $0 \mathrm{Cl22}-63-10$ & W-220587 & .25 & 31.0 & $<.02$ & 7.5 & $<1.0$ & .42 & -- & 56 & $<2.0$ & 4.6 & 13.0 & 5.0 \\
\hline $0 \mathrm{C122-63-14}$ & $\mathrm{W}-220588$ & .26 & 32.0 & $<.02$ & 7.5 & $<1.0$ & .40 & $\infty$ & 46 & $<2.0$ & 2.9 & 11.0 & 5.0 \\
\hline \multicolumn{14}{|l|}{ Station $5-18$} \\
\hline $0 \mathrm{Cl22-37-01}$ & W-220565 & .30 & 53.0 & $<.02$ & 2.3 & $<1.0$ & .16 & -- & 120 & $<2.0$ & 3.1 & $<2.0$ & 6.6 \\
\hline $0 \mathrm{C} 122-37-02$ & W-220566 & .31 & 54.0 & $<.02$ & 2.3 & $<1.0$ & .16 & - & 80 & $<2.0$ & 3.4 & $<2.0$ & 5.8 \\
\hline $0 \mathrm{C} 122-37-03$ & $W-220567$ & .30 & 61.0 & .05 & 2.3 & $<1.0$ & .16 & -- & 53 & $<2.0$ & 3.3 & $<2.0$ & 5.8 \\
\hline $0 C 122-37-04$ & $\mathrm{~W}-220568$ & .31 & 59.0 & .08 & 2.8 & $<1.0$ & .16 & - & 30 & $<2.0$ & 3.3 & $<2.0$ & 6.6 \\
\hline $0 \mathrm{C} 122-37-05$ & W-220569 & .32 & 40.0 & $<.02$ & 3.0 & $<1.0$ & .16 & -- & 33 & $<2.0$ & 3.0 & $<2.0$ & $<2.0$ \\
\hline $0 \mathrm{C} 122-37-06$ & $W-220570$ & .33 & 37.0 & .17 & 2.5 & $<1.0$ & .17 & -- & 33 & $<2.0$ & 3.1 & $<2.0$ & 4.4 \\
\hline $0 \mathrm{C} 122-37-10$ & $W-220571$ & .44 & 40.0 & .05 & 7.0 & $<1,0$ & .27 & -- & 132 & $<2.0$ & 3.5 & 2.5 & 6.6 \\
\hline $0 \mathrm{C} 122-37-22$ & W-220572 & .32 & 38.0 & .03 & 2.5 & $<1.0$ & .12 & -- & 47 & $<2.0$ & 1.8 & $<2.0$ & 4.4 \\
\hline \multicolumn{14}{|l|}{ Station 16} \\
\hline $0 C 122-36-B-01$ & $W-220557$ & 0.38 & 210.0 & $<0.02$ & 3.3 & 1.7 & 0.23 & -- & 150 & $<2.0$ & 5.5 & 2.5 & 12.0 \\
\hline $0 \mathrm{C} 122-36-\mathrm{B}-02$ & W-220558 & .29 & 110.0 & .03 & $<2.0$ & $<1.0$ & .14 & -- & 75 & $<2.0$ & 4.2 & $<2.0$ & 4.4 \\
\hline $0 \mathrm{C} 122-36-\mathrm{B}-03$ & W-220559 & .27 & 59.0 & .05 & $<2.0$ & $<1.0$ & .13 & -- & 16 & $<2.0$ & 3.4 & $<2.0$ & 4.4 \\
\hline $0 \mathrm{C} 122-36-\mathrm{B}-04$ & W-220560 & .27 & 33.0 & $<.02$ & $<2.0$ & $<1.0$ & .11 & - & $<10$ & $<2.0$ & 3.1 & $<2.0$ & 3.7 \\
\hline OC122-36-B-05 & W-220561 & .27 & 36.0 & .03 & $<2.0$ & $<1.0$ & .12 & - & 21 & $<2.0$ & 3.5 & $<2.0$ & 4.4 \\
\hline $0 \mathrm{Cl} 122-36-\mathrm{B}-06$ & W-220562 & .27 & 31.0 & .04 & $<2.0$ & $<1.0$ & .12 & -- & 26 & $<2.0$ & 3.0 & $<2.0$ & 3.7 \\
\hline OC122-36-B-10 & W-220563 & .34 & 36.0 & $<.02$ & 3.3 & $<1.0$ & .20 & - & 130 & $<2.0$ & 2.7 & $<2.0$ & 5.8 \\
\hline $0 \mathrm{C} 122-36-\mathrm{B}-22$ & W-220564 & .32 & 29.0 & .05 & $<2.0$ & $<1.0$ & .13 & -- & 24 & $<2.0$ & 2.1 & $<2.0$ & 4.4 \\
\hline \multicolumn{14}{|l|}{ Near station 7A } \\
\hline $0 \mathrm{c} 130-2 \times 0-2$ & W-222029 & 4.32 & 251.9 & .19 & 67.2 & 22.8 & 2.40 & .06 & 312 & 42.0 & 43.2 & 92.3 & 73.2 \\
\hline $0 \mathrm{C} 130-2 \times 2-4$ & W-222030 & 4.66 & 251.9 & .23 & 73.0 & 26.4 & 2.52 & .07 & 327 & 44.1 & 36.5 & 95.7 & 76.8 \\
\hline $0 \mathrm{c} 130-2 \times 4-6$ & W-222031 & 4.76 & 237.9 & .31 & 72.5 & 27.2 & 2.38 & .05 & 317 & 45.3 & 45.3 & 98.6 & 78.2 \\
\hline $0 C 130-2 \times 6-10$ & W-222032 & 5.05 & 234.8 & .27 & 79.8 & 28.2 & 2.58 & .07 & 305 & 50.5 & 48.1 & 108 & 83.3 \\
\hline $0 \mathrm{C} 130-2 \times 10-13$ & W-222033 & 4.69 & 218.1 & .20 & 68.7 & 27.3 & 2.51 & .04 & 316 & 46.9 & 38.2 & 103 & 79.6 \\
\hline \multicolumn{14}{|c|}{$6 \mathrm{~km}$ north of station $5-1$} \\
\hline $0 \mathrm{C} 130-3 \mathrm{AX} 2-10$ & $\mathrm{~W}-222034$ & 3.34 & 414.1 & .21 & 52.6 & 22.3 & 3.19 & .19 & 3663 & 38.2 & 51.0 & 92.4 & 79.6 \\
\hline $0 \mathrm{C} 130-3 \mathrm{~A} 2-10$ & W-222024 & .26 & 94.7 & .04 & 14.1 & 1.3 & .29 & .01 & 141 & $<2.0$ & 3.8 & 7.0 & 4.2 \\
\hline OC130-3BLXO-2 & $\mathrm{W}-222037$ & 2.80 & 381.7 & .24 & 40.7 & 20.4 & 2.52 & .10 & 2799 & 35.6 & 6.9 & 63.6 & 71.3 \\
\hline $0 \mathrm{C} 130-3 \mathrm{~B} \times 2-10$ & $\mathrm{~W}-222035$ & 2.21 & 294.5 & .29 & 34.4 & 20.4 & 2.18 & .11 & 3191 & 29.5 & 44.2 & 61.4 & 66.3 \\
\hline $0 C 130-3 B 2-10$ & W-222025 & .22 & 66.5 & $<.02$ & 3.5 & 1.2 & .24 & .01 & 99 & $<2.0$ & 3.3 & 5.0 & 4.2 \\
\hline $0 \mathrm{C1} 30-3 \mathrm{CX} 2-10$ & w-222036 & 2.86 & 450.2 & .39 & 43.0 & 24.6 & 3.07 & .15 & 6548 & 53.2 & 26.6 & 98.2 & 85.9 \\
\hline $0 \mathrm{C} 130-3 \mathrm{C} 2-10$ & W-222026 & .24 & 54.3 & $<.02$ & $<2.0$ & 1.2 & .29 & .01 & 191 & $<2.0$ & 4.0 & 7.5 & 4.2 \\
\hline
\end{tabular}


Table 5.--Chemical analysis of core samples and grab samples subsectioned in sequential depth intervals--Continued

\begin{tabular}{|c|c|c|c|c|c|c|c|c|c|c|c|c|c|}
\hline $\begin{array}{c}\text { Field } \\
\text { no. }\end{array}$ & $\begin{array}{l}\text { Lab } \\
\text { no. }\end{array}$ & $\begin{array}{c}\mathrm{Al} \\
\text { (percent) }\end{array}$ & $\begin{array}{c}\mathrm{Ba} \\
(\mathrm{ppm})\end{array}$ & $\begin{array}{c}\mathrm{Cd} \\
(\mathrm{ppm})\end{array}$ & $\begin{array}{c}\mathrm{Cr} \\
(\mathrm{ppm})\end{array}$ & $\begin{array}{c}\mathrm{Cu} \\
(\mathrm{ppm})\end{array}$ & $\begin{array}{c}\mathrm{Fe} \\
\text { (percent) }\end{array}$ & $\begin{array}{c}\mathrm{Hg} \\
(\mathrm{ppm})\end{array}$ & $\begin{array}{c}\mathrm{Mn} \\
\text { (ppm) }\end{array}$ & $\begin{array}{c}\mathrm{N1} \\
(\mathrm{ppm})\end{array}$ & $\begin{array}{c}\mathrm{Pb} \\
\text { (ppm) }\end{array}$ & $\begin{array}{c}\mathrm{V} \\
(\mathrm{ppm})\end{array}$ & $\begin{array}{c}\mathrm{Zn} \\
(\mathrm{ppm})\end{array}$ \\
\hline \multicolumn{14}{|c|}{$6 \mathrm{~km}$ south of station $5-1$} \\
\hline $0 \mathrm{C} 130-4 \mathrm{~A} 2-10$ & $\mathrm{~W}-222027$ & .81 & 130.7 & $<.02$ & 12.1 & 2.1 & .53 & .01 & 96 & $<2.0$ & 7.2 & 12.1 & 10.1 \\
\hline $0 \mathrm{C} 130-4 \mathrm{AX} 2-10$ & $\mathrm{~W}-222038$ & 4.29 & 650.4 & .29 & 65.0 & 27.3 & 3.25 & .12 & 442 & 42.9 & 82.0 & 117 & 91.1 \\
\hline $0 \mathrm{C} 130-4 \mathrm{~B} 2-10$ & $W-222028$ & .62 & 89.5 & $<.02$ & 11.1 & 1.6 & .42 & .01 & 78 & $<2.0$ & 8.1 & 10.1 & 7.5 \\
\hline OC130-4BLXO-2 & $W-222040$ & 3.91 & 916.9 & .19 & 55.3 & 24.3 & 2.97 & .07 & 405 & 35.1 & 33.7 & 97.1 & 75.5 \\
\hline $0 \mathrm{Cl} 30-4 \mathrm{BX} 2-10$ & W-222039 & 4.25 & 595.3 & .33 & 62.4 & 28.3 & 3.26 & .16 & 397 & 38.3 & 83.6 & 112 & 89.3 \\
\hline \multicolumn{14}{|c|}{$45 \mathrm{~km}$ southwest of station $5-1$} \\
\hline M09-19-00-GXO & $\mathrm{W}-222041$ & $\overline{4} .95$ & 288.8 & .10 & 79.8 & 22.0 & 3.16 & .07 & 509 & 35.8 & 28.9 & 99.0 & 77.0 \\
\hline MO9-19-00-GX2 & $\mathrm{w}-222042$ & 5.02 & 244.6 & .16 & 82.0 & 23.2 & 3.06 & .07 & 391 & 39.1 & 44.0 & 103 & 80.7 \\
\hline M09-19-00-GX4 & W-222043 & 4.96 & 230.9 & .20 & 73.9 & 25.4 & 3.00 & .06 & 369 & 38.1 & 50.8 & 106 & 84.3 \\
\hline M09-19-00-GX6 & W-222044 & 5.04 & $234 \cdot 3$ & .21 & 76.1 & 26.9 & 3.16 & .06 & 363 & 38.7 & 38.7 & 117 & 91.4 \\
\hline M09-19-00-GX8 & W-222045 & 5.03 & 233.8 & .20 & 80.7 & 25.7 & 3.16 & .07 & 397 & 42.1 & 36.2 & 101 & 87.7 \\
\hline \multicolumn{14}{|c|}{$45 \mathrm{~km}$ southwest of station 5-1 } \\
\hline MO9-19-00-HXO & W-222046 & $\overline{4} .54$ & 274.7 & .12 & 75.2 & 21.5 & 2.87 & .07 & 454 & 33.4 & 39.4 & 96.7 & 72.8 \\
\hline M09-19-00-HX2 & $\mathrm{W}-222047$ & 4.72 & 236.0 & .16 & 70.8 & 24.7 & 2.92 & .06 & 416 & 37.1 & 30.3 & 106 & 79.8 \\
\hline M09-19-00-HX4 & $\mathrm{W}-222048$ & 4.84 & 230.4 & .25 & 70.3 & 25.3 & 3.00 & .06 & 415 & 36.9 & 33.4 & 103 & 80.6 \\
\hline M09-19-00-HX6 & W-222049 & 4.75 & 220.2 & .31 & 77.7 & 24.3 & 3.13 & .05 & 440 & 38.3 & 44.0 & 109 & 81.1 \\
\hline \multicolumn{14}{|c|}{$20 \mathrm{~km}$ southwest of station $5-1$} \\
\hline M09-20-00-IX0 & $\mathrm{W}-222050$ & $\overline{0 \quad 3.72}$ & 402.3 & 0.22 & 59.6 & 19.4 & 2.83 & 0.07 & 477 & 32.8 & 65.6 & 89.4 & 74.5 \\
\hline M09-20-00-IX2 & $\mathrm{W}-222051$ & 4.06 & 420.0 & .23 & 65.0 & 23.0 & 2.98 & .07 & 379 & 29.8 & 44.7 & 107 & 82.7 \\
\hline M09-20-00-IX4 & W-222052 & 4.23 & 372.0 & .28 & 66.7 & 25.7 & 3.08 & .06 & 346 & 34.6 & 53.9 & 114 & 89.8 \\
\hline M09-20-00-IX6 & $\mathrm{W}-222053$ & 4.38 & 339.3 & .20 & 63.6 & 25.4 & 3.11 & .08 & 353 & 39.6 & 35.3 & 110 & 86.2 \\
\hline \multicolumn{14}{|c|}{$10 \mathrm{~km}$ southwest of station $5-1$} \\
\hline M09-21-00-IXO & $\mathrm{W}-222054$ & 4.03 & 552.8 & .19 & 61.3 & 26.9 & 2.99 & .09 & 433 & 32.9 & 34.4 & 108 & 79.2 \\
\hline M09-21-00-IX2 & W-222055 & 4.27 & 373.9 & .23 & 62.8 & 28.0 & 3.07 & .07 & 320 & 40.1 & 60.1 & 111 & 86.8 \\
\hline M09-21-00-IX4 & W-222056 & 3.99 & 384.7 & .19 & 59.8 & 25.6 & 2.99 & .07 & 313 & 41.3 & 52.7 & 107 & 78.4 \\
\hline M09-21-00-IX6 & $W-222057$ & 4.44 & 287.5 & .22 & 65.3 & 26.1 & 3.14 & .07 & 288 & 40.5 & 56.2 & 106 & 85.0 \\
\hline
\end{tabular}

$\left.\left(\mathrm{BaSO}_{4}\right) /(0.85 \mathrm{Ba})\right)=$ the ratio of molecular weights corrected for the estimated 85 percent $\mathrm{BaSO}_{4}$ concentration in mined barite.

We estimate that the sediments within $6 \mathrm{~km}$ of the drill site contained $308,000 \mathrm{lb}$ of barite at the time of well completion (cruise 5). By using the limits of the "most likely" range of barite discharged (1 million-1.5 million $\mathrm{lb}$ ), the amount of barite accounted for within $6 \mathrm{~km}$ of the rig represents between 21 and 31 percent of the total.

Samples collected during the remainder of the second year of monitoring permit an estimate of the rate at which barite has been removed from the site-specific survey area in block 312 . The inventory of barite was calculated from the analysis of primary site-specific stations collected on cruises 6 and 8 . High seas during cruise 7 prevented sampling at most primary stations.

By using the same calculations outlined above, we estimate that the sediments within $6 \mathrm{~km}$ of the drill site contained $178,000 \mathrm{lb}$ of barite in October 1982 (cruise 6) and 82,200 lb in May 1983 (cruise 8). The rate of decrease in the barite inventory relative to the amount present at cruise 5 (fig. 18) approximates the mathematical model for radioactive decay. The half-life or half-time of barite within the $6-\mathrm{km}$ circle is about 0.4 year. At this rate, the average $\mathrm{Ba}$ concentration in sediments within $6 \mathrm{~km}$ of the drilling rig is expected to be only about 10 percent higher than the predrilling concentration within approximately 1.5 years.

What is the fate of the barite that is unaccounted for within the $6-\mathrm{km}$ circle around the well in block 312? Some of the barite is being transported farther to the west. An increase in the $\mathrm{Ba}$ concentrations (in the fine fraction) of surface sediments compared to subsurface sediments was observed at the new stations 19,20 , and 21 and near station 7A (see p.19and fig. 15). A net increase in the $\mathrm{Ba}$ concentrations in the fine fraction of $750 \mathrm{ppm}$ was measured at regional station 12 on the eighth monitoring cruise (fig. 9). The signal at station $12,65 \mathrm{~km}$ to the west of the drilling activity, undoubtedly reflects a contribution from each of the eight wells on Georges Bank. No clear evidence exists of an increased $\mathrm{Ba}$ signal at stations 13 or $13 \mathrm{~A}$ from the analysis of surface samples, but analysis of sediment cores from this area is warranted.

Although the results are highly speculative, we have estimated the amount of barite, originating 

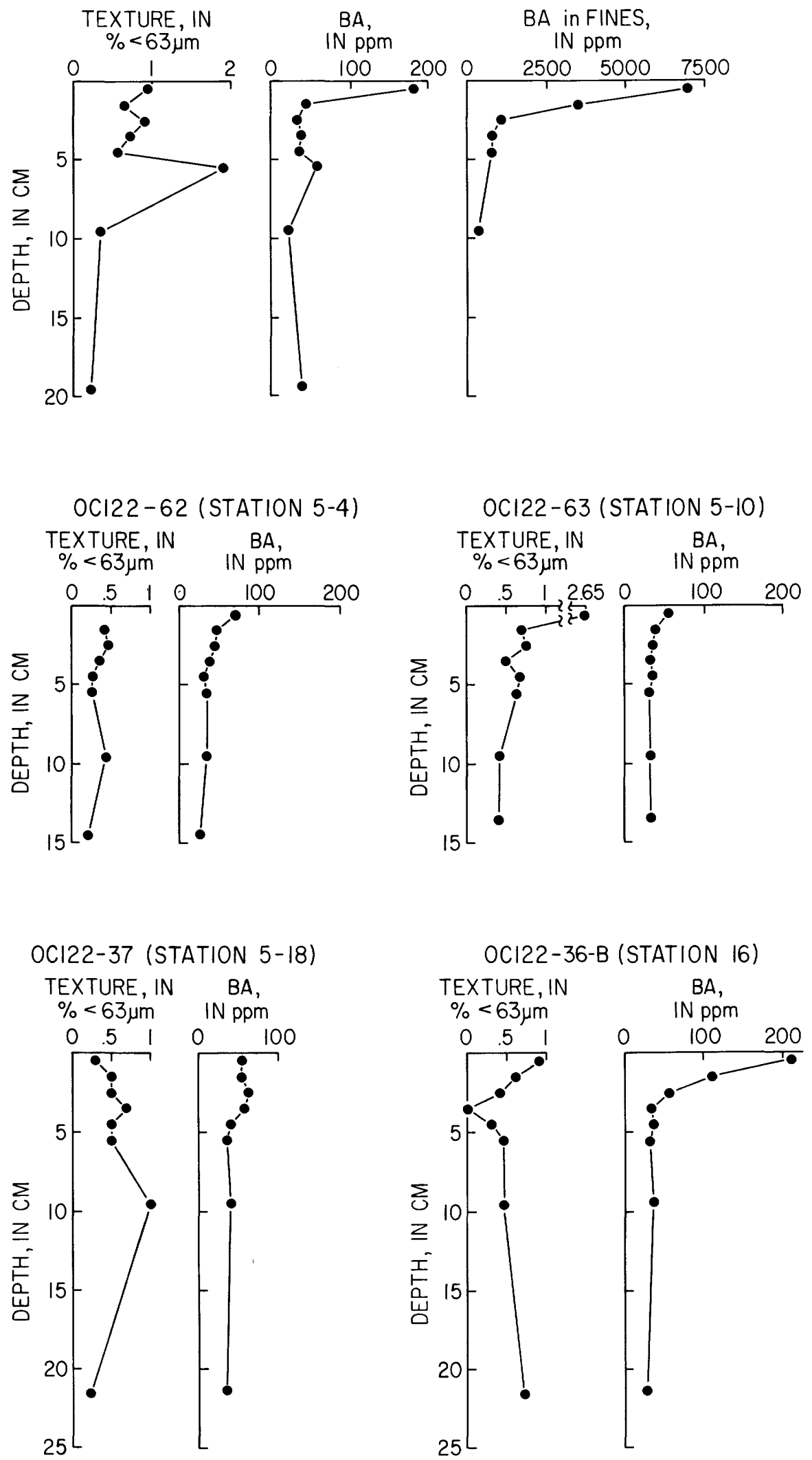

Figure 14.--Distribution of percent silt plus clay (less than $63 \mu \mathrm{m}$ size fraction) and distribution of barium with sediment depth. Samples were collected with a hydraulically damped gravity core during the second year of monitoring. 


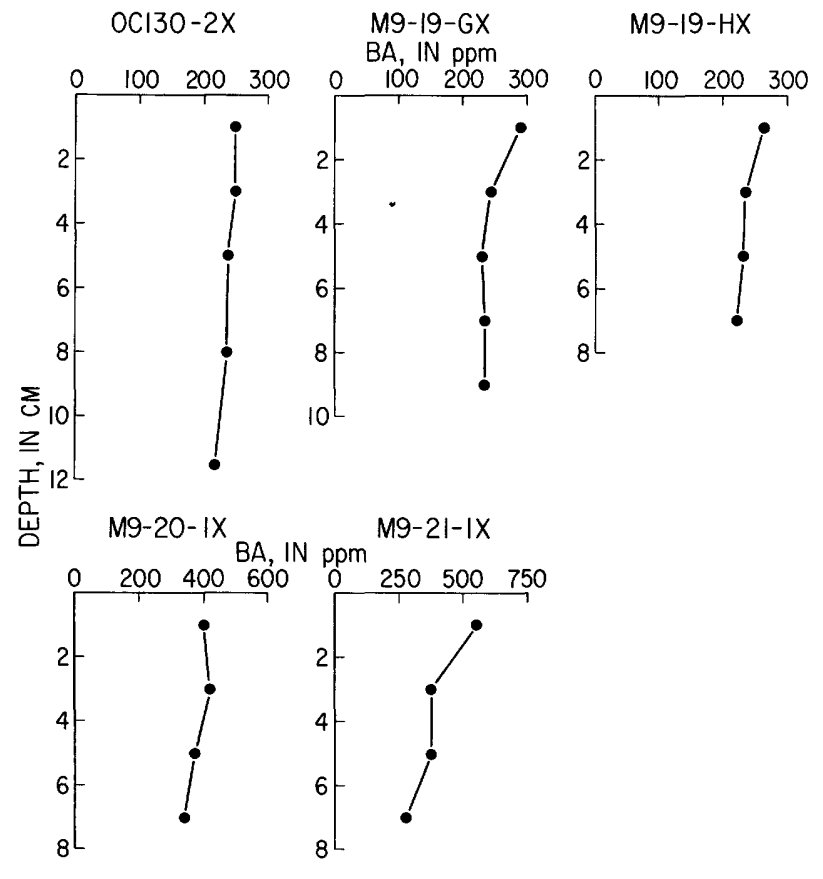

Figure 15.--Distribution of barium in the fine fraction (less than 60- $\mu \mathrm{m}$ size fraction) of sediment with sediment depth. Samples were collected with a grab sampler during the second year of monitoring and subsampled into sequential depth intervals. For station locations, see figure $1 A$ and appendix table $1 \mathrm{~B}$.

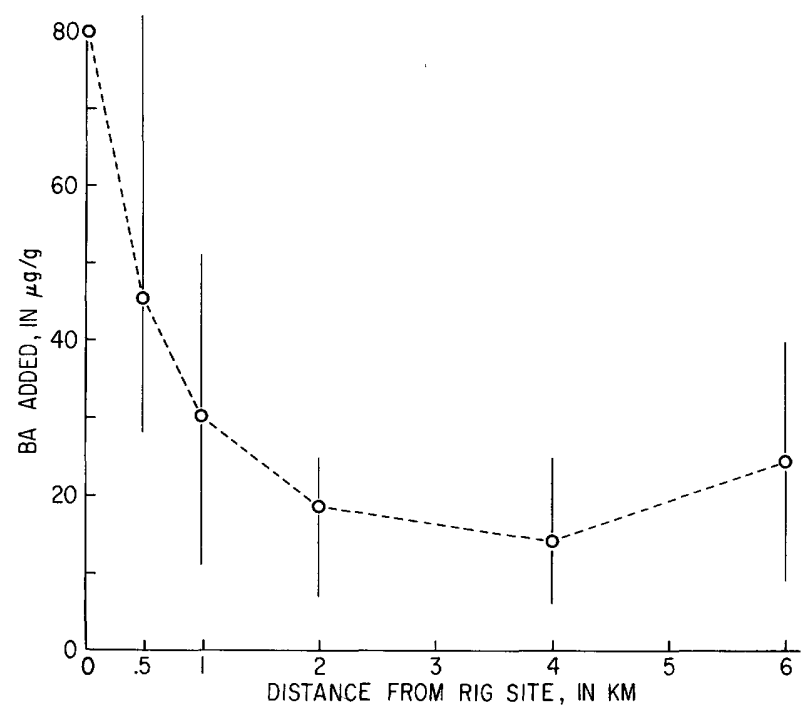

Figure 17.--Increase in average barium concentration of bulk sediment at different radial distances from the rig site in block 312 between the first (predrilling) and fifth monitoring cruises. Error bars represent the range of values among different stations at the same radial distance.

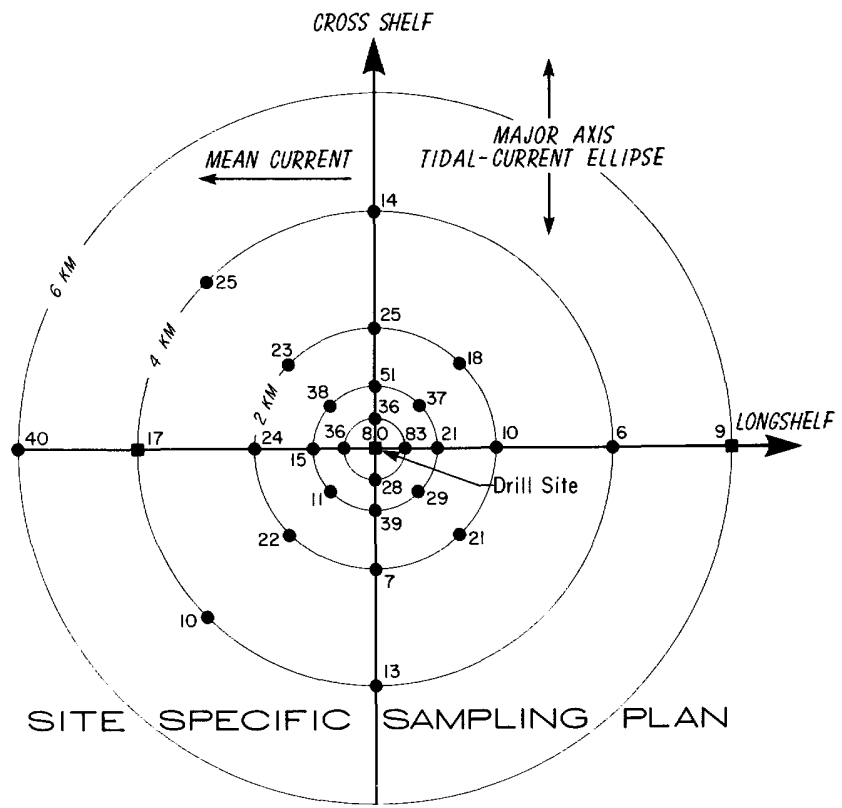

Figure 16.--Net increase in the concentration of barium in bulk sediments during the drilling period at block 312 (concentration at cruise 5 compared to concentration at cruise 1).

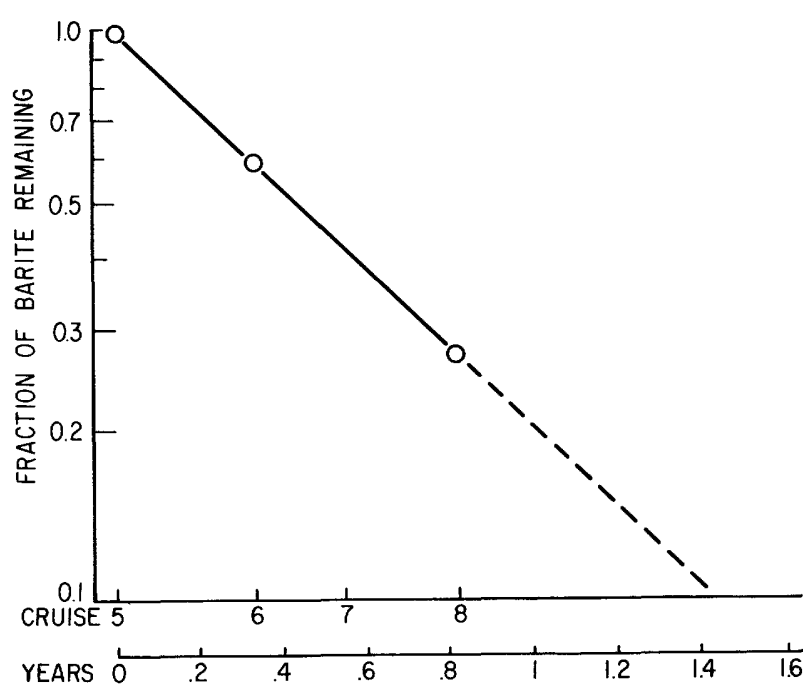

Figure 18,--Decrease of the barite inventory at block 312 with time relative to the amount present at the time of cruise 5,4 weeks after drilling was completed. 
from the eight wells, that is present within the fine fraction of sediments to the west of the drilling operations. For this rough calculation, we have made the following assumptions:

1. The area of $\mathrm{Ba}$ accumulation from all the wells is the western half of a circle with a radius of $65 \mathrm{~km}$ and centered at block 312. The distance farthest to the west where a Ba signal from drilling was measured is $65 \mathrm{~km}$.

2. The $\mathrm{Ba}$ is present in the sediment fraction finer than $60 \mu \mathrm{m}$, a size fraction that represents 2.7 percent of the bulk sediment (average of nine stations in this area).

3. The average net increase in the Ba concentration of the fine fraction within the upper $2 \mathrm{~cm}$ of the sediment ( $238 \mathrm{ppm})$ was determined as the average $\mathrm{Ba}$ signal above background of five stations between 10 and $65 \mathrm{~km}$ west of the drilling.

By using the same formula described above, we estimate the total inventory of drilling-related barite in the area between 6 and $65 \mathrm{~km}$ of block 312 to be 6.1 million $\mathrm{lb}$. We also assume that 26 percent of the barite discharged per well was initially deposited within $6 \mathrm{~km}$ of each well site and that, by the time of cruise 8 , the barite inventory was reduced to 7 percent of the amount discharged (fig. 18). This accounts for an estimated 0.7 million lb near the wells and a total inventory of 6.8 million ( 6.1 million +0.7 million) $\mathrm{lb}$ within the sediments.

A total of 12.6 million $\mathrm{lb}$ of barite was used to drill the eight wells on Georges Bank (Danenberger, 1983). The barite discharged to the ocean by Mobil wells in blocks 312 and 273 is assumed to be 52 percent of the amount used (middle of the most likely range of $42-63$ percent) because these wells did not have a bulk discharge of drilling mud at the completion of operations. We assume that the remaining six wells discharged 87 percent of the barite used, on the basis of the estimated discharge from a carefully monitored well on the Mid-Atlantic Continental Shelf (Ayers and others, 1982). We estimate that 9.8 million $\mathrm{lb}$ was actually discharged to the ocean on Georges Bank; the remainder was left in the holes or lost to porous formations while drilling.
Of the total barite discharged to Georges Bank, we find that 69 percent $(6.8 \mathrm{million} / 9.8 \mathrm{million})$ can be accounted for in the sediment adjacent to the drill rigs and in the area within $65 \mathrm{~km}$ to the west of the drilling. Because of sparse station coverage, we have ignored the area between wells to the east of block 312. Inclusion of this area might increase the percent of barite in our inventory and strengthen our conclusion that most of the barite is associated with the sediments at low concentrations in a wide area of the bank.

An additional process that may affect the fate and distribution of the barite is dissolution. Seawater is undersaturated with respect to $\mathrm{BaSO}_{4}$ (Chow, 1976; Dehairs and others, 1980); however, the rate of dissolution for land-derived barite is not well known. Furthermore, the $\mathrm{Ba}$ released by dissolution may be reprecipitated by certain planktonic organisms or during the decomposition of suspended-organic matter (Dehairs and others, 1980) and again may accumulate in underlying sediments. Such a cyclical process, if it occurs at a significant rate, would enhance the dispersion of $\mathrm{Ba}$ introduced with drilling mud.

\section{SUMMARY OF IMPORTANT FINDINGS}

1. Barium (present in barite, a major constituent of drilling mud) has increased by a factor of 5.9 in bulk (unfractionated) sediments 200 $\mathrm{m}$ from the drill site in block 410 as a result of drilling. The maximum barium concentration (172 ppm) was within the range of predrilling concentrations $(28 \mathrm{ppm}-300 \mathrm{ppm})$ measured at other sampling stations of this program. Because of the low toxicity of barium in the form of barite $\left(\mathrm{BaSO}_{4}\right)$, no adverse chemical stress to bottom-dwelling organisms is expected from these measured increases in barium concentrations. This prediction is being tested by the biological studies conducted within the monitoring program (BattelleWHOI, 1984). No drilling-related changes in the concentrations of chromium or of other metals have been observed in bulk sediments from any of the locations sampled in this program.

2. Of the barite discharged to the ocean waters while drilling in block 312 , we estimate that 21 to 31 percent was present in the sediments within $6 \mathrm{~km}$ of the well at the 
time of the fifth monitoring cruise, which was conducted 4 weeks after drilling was completed.

3. The inventory of barite, which accumulated as a result of drilling in block 312 , has decreased during the period following drilling, with a half-life of 0.4 year. By projecting this rate,we estimate that the average barium concentration within $6 \mathrm{~km}$ of the drilling site in block 312 will be no more than 10 percent above predrilling concentrations within approximately 1.5 years after completion of drilling. At block 410, a decrease in barium concentrations also has been measured during the second year of this program.

4. We determined that much of the barite not dedeposited close to the drilling rigs can be found in the fine fraction of sediment at distances as far as $65 \mathrm{~km}$ to the west of the drilling operations. Elevated barium concentrations in sediment-trap samples suggest that barite originally deposited near a drill site can be resuspended to at least $25 \mathrm{~m}$ above the sea floor. Transport of resuspended sediment to the west is consistent with the westerly current flow on this part of Georges Bank.

5. The elevated barium concentrations in bottom sediments are generally confined to within $2 \mathrm{~cm}$ of the water-sediment interface. We expect that any residual barium eventually will be mixed more deeply into the sediment column as a result of physical and biological reworking.

\section{REFERENCES CITED}

Ayers, R. C., Jr., Bowers, G., Gilmore, R. B., Mariani, G. M., Menzie, C. A., Mulligan, H. F., and Sauer, T. C., Jr., 1982, A study of environmental effects of exploratory drilling on the Mid-Atlantic Outer Continental Shelf--Final report of the Block 684 Monitoring Program: Prepared for Exxon Production Research Company, P.O. Box 2189, Houston, TX 77001, by EG\&G Environmental Consultants, 300 Bear Hill Road, Waltham, Mass.

Battelle-WHOI, 1984, Georges Bank benthic infaunal munitoring program, Final Report Year 2: Prepared for the Department of the Interior, Minerals Management Service [Contract no. 14-12-001-29192] by Battelle New England Marine Research Laboratory, 397 Washington Street,
Duxbury, Mass., and Woods Hole Oceanographic Institution, Woods Hole, Mass., $315 \mathrm{p}$.

Bothner, M. H., Rendigs, R. R., Campbell, Esma, Doughton, M. W., Aruscavage, P. J., Dorrzapf, A. F., Jr., Johnson, R. G., Parmenter, C. M., Pickering, M. J., Brewster, D. C., and Brown, F. W., 1984, The Georges Bank Monitoring Program 1983: Analysis of trace metals in bottom sediments: U. S. Geological Survey Circular 915, prepared in cooperation with the U.S. Minerals Management Service under Interagency Agreement AA851-1A2-18, 36 p.

Bothner, M. H., Spiker, E. C., Johnson, P. P., Rendigs, R. R., and Aruscavage, P. J., 1981, Geochemical evidence for modern sediment accumulation on the Continental Shelf off Southern New England: Journal of Sedimentary Petrology, v. 51, p. 281-292.

Butman, Bradford, Beardsley, R. C., Magnell, Bruce. Frye, Daniel, Vermersch, J. A., Schlitz, Ronald, Limeburner, Richard, Wright, W. R., and Noble, M. A., 1982a. Recent observations of the mean circulation on Georges Bank: Journal of Physical Oceanography, v. 12, p. 569-591.

Butman, Bradford, Bothner, M. H., Noble, M. A., and Twichell, D. C., 1982b, The Lydonia Canyon Experiment: Preliminary results [abs.]: EOS, Transactions, American Geophysical Union, v. 63, p. 349 .

Butman, Bradford, and Folger, D. W ., 1979, An instrument system for long-term sediment transport studies on the Continental Shelf: Journal of Geophysical Research, v. 84, p. 1215-1220.

Butman, Bradford, and Moody, J. A., 1983, Observations of bottom currents and sediment movement along the U.S. East Coast Continental Shelf during winter, in McGregor, B. A., ed., Environmental geologic studies of the United States east coast Mid and North Atlantic Outer Continental Shelf area, 1980-1982, Volume III., North Atlantic region: U .S. Geological Survey Final Report to Minerals Management Service, chapter 7,84 p.

Chow, T.J., 1976, Barium in southern California coastal waters: A potential indicator of marine drilling contamination: Science, v. 193, p. 57-58.

Cooper, R. A., and Uzmann, J.R., 1981, Georges Bank and submarine canyon living resources and habitat baselines in oil and gas drilling areas, contribution to Annual NEMP report on the health of the northeast coastal waters of the United States, 1981: NOAA Technical Memoir NMFSF/NEC20, $35 \mathrm{p}$.

Crecelius, E. A., Bothner, M. H., and Carpenter, Roy., 1975. The geochemistries of arsenic, antimony, mercury, and related elements in sediments of Puget Sound, Washington: Environmental Science and Technology, v. 9, no. 4, p. 325333.

Danenberger, E. P., 1983, Georges Bank exploratory drilling (1981-1982): U. S. Department of the Interior, Minerals Management Service, North Atlantic District, Barnstable Municipal Airport, East Ramp, Hyannis, Mass., 20 p.

Dehairs, F. Chesselet, R., and Jedwab, J. 1980, Discrete suspended particles of barite and the barium cycle in the open ocean: Earth and Planetary Science Letters, v. 49, p. 528550 .

Johnson, R. G., 1984, Trace element analysis of silicates by means of energy dispersive X-ray spectrometry: X-Ray Spectrometry, v. 13, no. 1 [in press]. 
Krumbein, W. C., and Pettijohn, F. J., 1938, Manual of sedimentary petrography: New York, Appleton-Century-Croft, $549 \mathrm{p}$.

Michael, A. D., Long, C. D., Mauer, Donald, and McGrath, R. A., 1983, Georges Bank benthic infauna historical study: A final report submitted to the U.S. Department of the Interior, Minerals Management Service, Contract 14-12. 0001-29190, Taxon, Inc., Salem, Mass., 171 p.

Pamatmat, M. M., 1971, Oxygen consumption by the seabed, iv. shipboard and laboratory experiments: Limnology and Oceanography, v. 16, p. 536-550.
Parmenter, C. M., Bothner, M. H., and Butman, Bradford, 1984, Characteristics of resuspended material from Georges Bank collected with a sediment trap: Estuarine, Coastal and Marine Science, v. 17.p. 521-533.

Schlee, J. S., 1966, A modified Woods Hole rapid sediment analyzer: Journal of Sedimentary Petrology, v. 36, p. 403413.

Twichell, D. C., McClennen, C. E., and Butman, Bradford, 1981, Morphology and processes associated with the accumulation of the fine-grained sediment deposit on the Southern New England Shelf: Journal of Sedimentary Petrology, v. 51.p. 269-280. 
[T1 (Caribou, Maine) and T4 (Carolina Beach, N.C.) are Loran-C time delay values for the 9960 Loran-C chain]

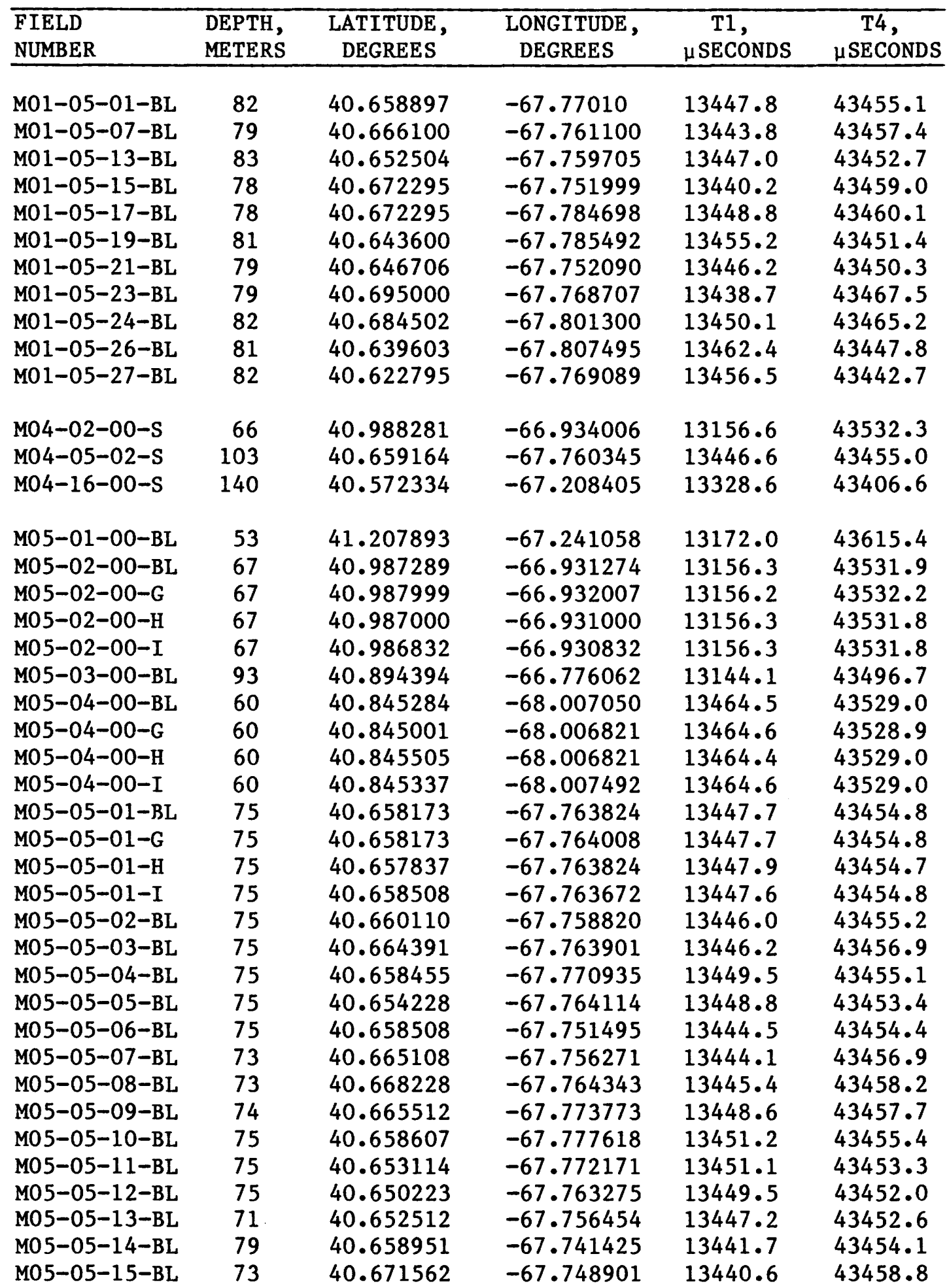




\begin{tabular}{|c|c|c|c|c|c|}
\hline $\begin{array}{l}\text { FIELD } \\
\text { NUMBER } \\
\end{array}$ & $\begin{array}{l}\text { DEPTH, } \\
\text { METERS }\end{array}$ & $\begin{array}{c}\text { LATITUDE, } \\
\text { DEGREES }\end{array}$ & $\begin{array}{c}\text { LONGITUDE, } \\
\text { DEGREES }\end{array}$ & $\begin{array}{c}\text { Tl, } \\
\mu \mathrm{SECONDS}\end{array}$ & $\begin{array}{c}\text { T4, } \\
\mu \text { SECONDS }\end{array}$ \\
\hline M05-05-16-BL & 73 & 40.676559 & -67.764038 & 13443.3 & 43461.1 \\
\hline M05-05-17-BL & 74 & 40.671509 & -67.778534 & 13448.3 & 43459.9 \\
\hline M05-05-18-BL & 75 & 40.659775 & -67.787552 & 13453.5 & 43456.2 \\
\hline M05-05-19-BL & 76 & 40.646057 & -67.781067 & 13455.1 & 43451.3 \\
\hline M05-05-20-BL & 72 & 40.639565 & -67.762344 & 13451.9 & 43448.3 \\
\hline M05-05-21-BL & 69 & 40.646278 & -67.747223 & 13446.3 & 43450.1 \\
\hline M05-05-22-BL & 78 & 40.658890 & -67.719894 & 13436.2 & 43453.4 \\
\hline M05-05-23-BL & 73 & 40.695229 & -67.764404 & 13438.8 & 43467.5 \\
\hline M05-05-24-BL & 75 & 40.685051 & -67.797333 & 13449.9 & 43465.3 \\
\hline M05-05-25-BL & 76 & 40.659897 & -67.809830 & 13459.3 & 43457.2 \\
\hline M05-05-26-BL & 76 & 40.632950 & -67.796600 & 13462.4 & 43447.3 \\
\hline M05-05-27-BL & 75 & 40.622665 & -67.763718 & 13456.4 & 43442.6 \\
\hline M05-05-28-BL & 71 & 40.658775 & -67.694000 & 13429.5 & 43452.3 \\
\hline M05-05-29-BL & 78 & 40.662552 & -67.840057 & $13466 \cdot 6$ & 43459.1 \\
\hline M05-06-00-BL & 92 & 40.574051 & -67.754791 & 13465.8 & 43425.5 \\
\hline M05-07-A0-BL & 161 & 40.535385 & -67.736282 & 13470.3 & 43411.4 \\
\hline M05-08-00-BL & 140 & 40.452171 & -67.617996 & 13459.7 & 43378.9 \\
\hline M05-09-00-BL & 137 & 40.445053 & -68.165176 & 13603.8 & 43394.3 \\
\hline M05-10-00-BL & 56 & 40.698891 & $-68 \cdot 588776$ & 13661.7 & 43502.6 \\
\hline M05-11-00-BL & 77 & 40.512390 & $-68 \cdot 562607$ & 13697.9 & 43433.3 \\
\hline M05-12-00-BL & 98 & 40.368889 & -68.499664 & 13712.8 & 43378.0 \\
\hline M05-13-AO-BL & 74 & 40.500565 & -71.008820 & 14463.9 & 43544.2 \\
\hline M05-13-00-BL & 62 & 40.487000 & -70.209625 & 14201.9 & 43496.0 \\
\hline $\mathrm{M} 05-13-\mathrm{A} 0-\mathrm{G}$ & 74 & 40.501671 & -71.009171 & 14463.8 & 43544.6 \\
\hline M05-13-A0-H & 74 & 40.500000 & -71.008667 & 14464.0 & 43544.0 \\
\hline M05-13-A0-I & 74 & 40.500000 & -71.008667 & 14463.9 & 43544.0 \\
\hline M05-14-A0-BL & 165 & 41.958176 & -68.517990 & 13299.0 & 43931.2 \\
\hline M05-15-00-BL & 43 & 41.457001 & -68.010178 & 13302.4 & 43735.3 \\
\hline M05-16-00-BL & 132 & 40.573059 & -67.207062 & 13328.0 & 43406.8 \\
\hline M05-16-00-G & 132 & 40.573334 & -67.207489 & 13328.1 & 43406.9 \\
\hline M05-16-00-H & 132 & 40.572838 & -67.207169 & 13328.1 & 43406.7 \\
\hline M05-16-00-I & 132 & 40.572998 & -67.206512 & 13327.9 & 43406.8 \\
\hline M05-17-00-BL & 138 & 40.583603 & -67.186218 & 13320.4 & 43409.7 \\
\hline M05-18-00-BL & 139 & 40.558777 & -67.224503 & 13335.8 & 43402.6 \\
\hline M06-01-00-BL & 58 & 41.207230 & -67.242279 & 13172.4 & 43615.2 \\
\hline M06-02-00-BL & 71 & 40.986740 & -66.932587 & 13156.7 & 43531.8 \\
\hline M06-02-00-G & 71 & 40.986832 & -66.932495 & 13156.6 & 43531.9 \\
\hline M06-02-00-H & 71 & 40.986832 & -66.932831 & 13156.7 & 43531.8 \\
\hline M06-02-00-I & 71 & 40.986671 & -66.932159 & 13156.6 & 43531.8 \\
\hline M06-03-00-BL & 95 & 40.902451 & -66.798553 & 13147.3 & 43500.0 \\
\hline M06-04-00-BL & 65 & 40.846001 & -68.003021 & 13464.4 & 43529.1 \\
\hline M06-04-00-G & 65 & 40.845840 & -68.002670 & 13464.4 & 43529.0 \\
\hline M06-04-00-H & 65 & 40.846176 & -68.003021 & 13464.4 & 43529.2 \\
\hline M06-04-00-I & 65 & 40.846001 & -68.003326 & 13464.5 & 43529.2 \\
\hline M06-05-01-BL & 79 & 40.657944 & -67.764496 & 13448.0 & 43454.7 \\
\hline M06-05-01-G & 79 & 40.658676 & -67.764496 & 13447.8 & 43454.9 \\
\hline M06-05-01-H & 79 & 40.657997 & -67.764679 & 13448.0 & 43454.7 \\
\hline
\end{tabular}


Appendix table 1A. --Navigation data for station blends and individual samples analyzed for chemistry--

Continued

\begin{tabular}{|c|c|c|c|c|c|}
\hline $\begin{array}{l}\text { FIELD } \\
\text { NUMBER } \\
\end{array}$ & $\begin{array}{l}\text { DEPTH, } \\
\text { METERS }\end{array}$ & $\begin{array}{c}\text { LATITUDE, } \\
\text { DEGREES }\end{array}$ & $\begin{array}{c}\text { LONGITUDE, } \\
\text { DEGREES }\end{array}$ & $\begin{array}{c}\mathrm{T} 1, \\
\mu \mathrm{SECONDS}\end{array}$ & $\begin{array}{c}\text { T4, } \\
\mu \mathrm{SECONDS} \\
\end{array}$ \\
\hline M06-05-01-I & 79 & 40.657509 & -67.764343 & 13448.1 & 43454.6 \\
\hline M06-05-02-BL & 78 & 40.660110 & -67.758713 & 13445.9 & 43455.2 \\
\hline M06-05-03-BL & 78 & 40.664230 & -67.765106 & 13446.6 & 43456.9 \\
\hline M06-05-04-BL & 79 & 40.658951 & -67.771515 & 13449.5 & 43455.3 \\
\hline M06-05-05-BL & 81 & 40.654457 & -67.765289 & 13449.0 & 43453.5 \\
\hline M06-05-06-BL & 78 & 40.658455 & $-67 \cdot 752502$ & 13444.7 & 43454.4 \\
\hline M06-05-08-BL & 77 & 40.668335 & $-67 \cdot 764038$ & 13445.3 & 43458.3 \\
\hline M06-05-09-BL & 78 & 40.665565 & -67.774506 & 13448.7 & 43457.7 \\
\hline M06-05-10-BL & 80 & 40.658279 & -67.778610 & 13451.6 & 43455.4 \\
\hline M06-05-11-BL & 80 & 40.653175 & -67.773621 & 13451.5 & 43453.4 \\
\hline M06-05-12-BL & 80 & 40.650833 & -67.764175 & 13449.6 & 43452.3 \\
\hline M06-05-14-BL & 79 & 40.658676 & -67.740448 & 13441.5 & 43454.1 \\
\hline M06-05-16-BL & 77 & 40.676170 & -67.763901 & 13443.4 & 43460.9 \\
\hline M06-05-18-BL & 80 & 40.659508 & $-67 \cdot 788727$ & 13453.9 & 43456.2 \\
\hline M06-05-20-BL & 78 & 40.639671 & -67.763062 & 13452.0 & 43448.4 \\
\hline M06-05-22-BL & 77 & 40.659836 & -67.720001 & 13435.9 & 43453.7 \\
\hline M06-05-25-BL & 81 & 40.659676 & -67.811005 & 13459.7 & 43457.0 \\
\hline M06-05-28-BL & 75 & 40.659050 & -67.694504 & 13429.5 & 43452.5 \\
\hline M06-05-29-BL & 83 & 40.662560 & -67.839996 & 13466.6 & 43459.2 \\
\hline M06-06-00-BL & 98 & 40.574280 & -67.755402 & 13465.9 & 43425.6 \\
\hline MO6-07-A0-BL & 165 & 40.535675 & -67.737167 & 13470.4 & 43411.6 \\
\hline M06-08-00-BL & 145 & 40.451393 & -67.619400 & 13460.3 & 43378.6 \\
\hline M06-09-00-BL & 141 & 40.445107 & $-68 \cdot 162277$ & 13604.1 & 43394.3 \\
\hline M06-10-00-BL & 58 & 40.699112 & -68.585098 & 13661.8 & 43502.7 \\
\hline M06-11-00-BL & 83 & 40.513229 & -68.559097 & 13697.8 & 43433.6 \\
\hline M06-12-00-BL & 103 & 40.369057 & $-68 \cdot 496460$ & 13712.9 & 43378.1 \\
\hline MO6-13-00-BL & 67 & 40.487282 & -70.207062 & 14201.9 & 43496.0 \\
\hline MO6-13-A0-BL & 78 & 40.500053 & -71.008102 & 14464.1 & 43544.0 \\
\hline M06-13-A0-G & 78 & 40.500504 & -71.007675 & 14463.9 & 43544.2 \\
\hline M06-13-AO-H & 78 & 40.500000 & -71.008499 & 14464.2 & 43544.0 \\
\hline M06-13-A0-I & 78 & 40.500168 & -71.008331 & 14464.1 & 43544.1 \\
\hline MO6-14-A0-BL & 168 & 41.958336 & $-68 \cdot 575287$ & 13299.4 & 43931.4 \\
\hline M06-15-00-BL & 71 & 41.456612 & -68.009903 & 13302.4 & 43735.1 \\
\hline M06-16-00-BL & 138 & 40.572449 & $-67 \cdot 207916$ & 13328.4 & 43406.6 \\
\hline M06-16-00-G & 138 & 40.572510 & -67.207947 & 13328.4 & 43406.7 \\
\hline M06-16-00-H & 138 & 40.572510 & -67.208176 & 13328.5 & 43406.6 \\
\hline M06-16-00-I & 138 & 40.572510 & -67.207993 & 13328.4 & 43406.6 \\
\hline M06-17-00-BL & 141 & 40.582840 & -67.185913 & 13320.5 & 43409.4 \\
\hline M06-18-00-BL & 145 & 40.558388 & -67.225067 & 13336.0 & 43402.5 \\
\hline M06-18-00-G & 145 & 40.558510 & $-67 \cdot 225830$ & 13336.2 & 43402.6 \\
\hline M06-18-00-H & 145 & 40.558510 & -67.224670 & 13335.9 & 43402.5 \\
\hline M06-18-00-I & 144 & 40.558174 & -67.224670 & 13336.0 & 43402.4 \\
\hline M07-01-00-BL & 58 & 41.184746 & -67.240509 & 13178.2 & 43608.0 \\
\hline M07-02-00-BL & 71 & 40.987289 & -66.932999 & 13156.7 & 43532.0 \\
\hline$M 07-02-00-G$ & 71 & 40.986671 & -66.933334 & 13156.8 & 43531.8 \\
\hline M07-02-00-H & 71 & 40.987999 & -66.933334 & 13156.6 & 43532.3 \\
\hline M07-02-00-I & 71 & 40.987167 & -66.932343 & 13156.6 & 43531.9 \\
\hline
\end{tabular}




\begin{tabular}{|c|c|c|c|c|c|}
\hline $\begin{array}{l}\text { FIELD } \\
\text { NUMBER } \\
\end{array}$ & $\begin{array}{l}\text { DEPTH, } \\
\text { METERS }\end{array}$ & $\begin{array}{c}\text { LATITUDE, } \\
\text { DEGREES }\end{array}$ & $\begin{array}{c}\text { LONGITUDE, } \\
\text { DEGREES }\end{array}$ & $\begin{array}{c}\mathrm{Tl}, \\
\mu \mathrm{SECONDS} \\
\end{array}$ & $\begin{array}{c}\text { T4, } \\
\mu \text { SECONDS } \\
\end{array}$ \\
\hline M07-03-00-BL & 96 & 40.894508 & -66.777283 & 13144.4 & 43496.7 \\
\hline M07-05-01-BL & 81 & 40.658455 & -67.764008 & 13447.7 & 43454.8 \\
\hline M07-05-01-G & 81 & 40.658173 & -67.764496 & 13447.9 & 43454.7 \\
\hline M07-05-01-H & 81 & 40.658676 & -67.765015 & 13447.9 & 43455.0 \\
\hline M07-05-01-I & 81 & 40.658508 & -67.762497 & 13447.3 & 43454.8 \\
\hline M07-05-28-BL & 76 & 40.658508 & -67.694717 & 13429.7 & 43452.3 \\
\hline M07-05-28-G & 76 & 40.658340 & -67.694000 & 13429.6 & 43452.2 \\
\hline M07-05-28-H & 76 & 40.659676 & -67.694824 & 13429.5 & 43452.6 \\
\hline M07-05-28-I & 76 & 40.657509 & -67.695343 & 13430.1 & 43452.0 \\
\hline M07-06-00-BL & 98 & 40.581017 & -67.756027 & 13464.4 & 43427.9 \\
\hline $\mathrm{MO} 7-07-\mathrm{AO}-\mathrm{BL}$ & 165 & 40.532455 & -67.733887 & 13470.2 & 43410.4 \\
\hline M07-07-A0-G & 165 & 40.529015 & -67.728836 & 13469.7 & 43409.0 \\
\hline M07-07-A0-H & 165 & 40.534164 & $-67 \cdot 737015$ & 13470.5 & 43411.1 \\
\hline M07-07-A0-I & 165 & 40.534164 & -67.735825 & 13470.5 & 43411.1 \\
\hline M07-08-00-BL & 142 & 40.452110 & $-67 \cdot 618179$ & 13459.7 & 43378.9 \\
\hline M07-10-00-BL & 58 & 40.698959 & -68.585541 & 13661.9 & 43502.6 \\
\hline M07-13-00-BL & 66 & 40.486832 & -70.206619 & 14201.9 & 43495.9 \\
\hline M07-13-00-G & 66 & 40.486671 & -70.206177 & 14201.8 & 43495.8 \\
\hline M07-13-00-H & 66 & 40.487671 & -70.206665 & 14201.8 & $43496 \cdot 3$ \\
\hline M07-13-00-I & 66 & 40.486168 & -70.207001 & 14202.1 & 43495.7 \\
\hline $\mathrm{M} 07-14-\mathrm{A0}-\mathrm{BL}$ & 168 & 41.958176 & -68.517944 & 13299.1 & 43931.2 \\
\hline$M 07-14-A 0-G$ & 168 & 41.958672 & $-68 \cdot 517838$ & 13298.9 & 43931.3 \\
\hline M07-14-AO-H & 168 & 41.957680 & -68.517670 & 13299.1 & 43931.1 \\
\hline M07-14-A0-I & 168 & 41.958176 & -68.518341 & 13299.2 & 43931.3 \\
\hline M07-15-00-BL & 38 & 41.457413 & -68.010284 & 13302.3 & 43735.4 \\
\hline M07-16-00-BL & 143 & 40.572105 & -67.208221 & 13328.6 & 43406.6 \\
\hline M07-16-00-G & 143 & 40.572174 & -67.207993 & 13328.5 & 43406.5 \\
\hline M07-16-00-H & 143 & 40.572670 & -67.209320 & 13328.7 & 43406.8 \\
\hline$M 07-16-00-I$ & 143 & 40.571510 & -67.207321 & 13328.5 & 43406.4 \\
\hline M07-17-00-G & 144 & 40.581833 & -67.185181 & 13320.6 & 43409.0 \\
\hline M07-17-00-H & 144 & 40.584335 & -67.186005 & 13320.2 & 43409.9 \\
\hline M07-17-00-I & 144 & 40.582336 & -67.186829 & 13320.9 & 43409.2 \\
\hline M07-18-00-BL & 147 & 40.558250 & -67.223618 & 13335.8 & 43402.4 \\
\hline M08-01-00-BL & 58 & 612 & -67 & 1317 & 43614.9 \\
\hline M08-02-00-BL & 73 & 40.986954 & -66.932495 & 13156.6 & 43531.8 \\
\hline M08-02-00-G & 73 & 40.987679 & -66.93385 .3 & 13156.8 & 43532.1 \\
\hline M08-02-00-H & 73 & 40.986504 & -66.932159 & 13156.6 & 43531.7 \\
\hline M08-02-00-I & 73 & 40.986671 & -66.931503 & 13156.4 & 43531.7 \\
\hline M08-03-00-BL & 97 & 40.894669 & -66.776215 & 13144.2 & 43496.7 \\
\hline M08-04-00-BL & 66 & 40.846107 & -68.003632 & $13464 \cdot 6$ & 43529.2 \\
\hline M08-04-00-G & 66 & 40.846001 & -68.003174 & 13464.5 & 43529.1 \\
\hline $\mathrm{M} 08-04-00-\mathrm{H}$ & 66 & 40.846664 & -68.003174 & 13464.3 & 43529.4 \\
\hline M08-04-00-I & 66 & 40.845673 & -68.004501 & 13464.9 & 43529.2 \\
\hline M08-05-01-BL & 81 & 40.658676 & -67.763443 & 13447.5 & 43454.9 \\
\hline M08-05-01-G & 81 & 40.658340 & -67.763824 & 13447.7 & 43454.7 \\
\hline M08-05-01-H & 81 & 40.658836 & -67.762665 & 13447.3 & 43455.0 \\
\hline M08-05-01-I & 81 & 40.658836 & -67.763824 & 13447.6 & 43455.0 \\
\hline
\end{tabular}




\begin{tabular}{|c|c|c|c|c|c|}
\hline $\begin{array}{l}\text { FIELD } \\
\text { NUMBER } \\
\end{array}$ & $\begin{array}{l}\text { DEPTH, } \\
\text { METERS }\end{array}$ & $\begin{array}{c}\text { LATITUDE, } \\
\text { DEGREES }\end{array}$ & $\begin{array}{c}\text { LONGITUDE, } \\
\text { DEGREES }\end{array}$ & $\begin{array}{c}\text { T1, } \\
\mu \mathrm{SECONDS}\end{array}$ & $\begin{array}{c}\text { T4, } \\
\mu \text { SECONDS }\end{array}$ \\
\hline M08-05-02-BL & 80 & 40.659714 & -67.758957 & 13446.1 & 43455.1 \\
\hline M08-05-03-BL & 79 & 40.663956 & -67.763901 & 13446.4 & 43456.8 \\
\hline M08-05-04-BL & 82 & 40.659607 & -67.770828 & 13449.1 & 43455.5 \\
\hline M08-05-05-BL & 82 & 40.654831 & -67.765106 & 13448.8 & 43453.7 \\
\hline M08-05-06-BL & 81 & 40.656563 & -67.750504 & 13444.7 & 43453.7 \\
\hline M08-05-08-BL & 80 & 40.668282 & -67.763168 & 13445.1 & 43458.2 \\
\hline M08-05-09-BL & 81 & 40.666000 & -67.774399 & 13448.6 & 43457.8 \\
\hline M08-05-10-BL & 82 & 40.658455 & -67.777313 & 13451.2 & 43455.4 \\
\hline M08-05-11-BL & 82 & 40.653175 & -67.772156 & 13451.1 & 43453.4 \\
\hline M08-05-12-BL & 80 & 40.649948 & -67.763016 & 13449.6 & 43452.0 \\
\hline M08-05-14-BL & 79 & 40.658890 & -67.740829 & 13441.5 & 43454.2 \\
\hline M08-05-16-BL & 78 & 40.676392 & -67.763779 & 13443.2 & 43461.0 \\
\hline M08-05-18-BL & 82 & 40.659286 & -67.788605 & 13453.8 & 43456.2 \\
\hline M08-05-20-BL & 80 & 40.639450 & -67.761902 & 13451.8 & 43448.3 \\
\hline M08-05-22-BL & 79 & 40.659111 & -67.719162 & 13435.9 & 43453.4 \\
\hline M08-05-25-BL & 82 & 40.659714 & -67.811783 & 13459.9 & 43457.0 \\
\hline M08-05-28-BL & 79 & 40.658775 & -67.694534 & 13429.6 & 43452.4 \\
\hline M08-05-29-BL & 82 & 40.662056 & -67.839554 & 13466.5 & 43459.0 \\
\hline M08-06-00-BL & 98 & 40.573837 & -67.754227 & 13465.7 & 43425.4 \\
\hline M08-07-A0-BL & 167 & 40.534996 & -67.735779 & 13470.3 & 43411.4 \\
\hline M08-08-00-BL & 146 & 40.452332 & -67.618225 & 13459.7 & 43379.0 \\
\hline M08-09-00-BL & 143 & 40.444611 & $-68 \cdot 162109$ & 13604.2 & 43394.1 \\
\hline M08-10-00-BL & 62 & 40.699448 & -68.584610 & 13661.6 & 43502.8 \\
\hline M08-11-00-BL & 84 & 40.512955 & -68.559494 & 13698.0 & 43433.4 \\
\hline M08-12-00-BL & 105 & 40.369614 & -68.492523 & 13711.7 & 43378.1 \\
\hline M08-13-00-BL & 70 & 40.487167 & -70.206451 & 14201.8 & 43496.0 \\
\hline M08-13-A0-BL & 80 & 40.500000 & -71.010284 & 14464.8 & 43544.1 \\
\hline M08-13-A0-G & 80 & 40.500000 & -71.010498 & 14464.9 & 43544.1 \\
\hline $\mathrm{M} 08-13-\mathrm{AO}-\mathrm{H}$ & 80 & 40.499832 & -71.010666 & 14464.9 & 43544.0 \\
\hline M08-13-A0-I & 80 & 40.500168 & -71.009674 & 14464.6 & 43544.2 \\
\hline M08-14-A0-BL & 172 & 41.958611 & -68.520050 & 13299.6 & 43931.5 \\
\hline M08-15-00-BL & 40 & 41.457558 & -68.011719 & 13302.8 & 43735.5 \\
\hline M08-16-00-BL & 139 & 40.572174 & -67.206161 & 13328.6 & 43406.6 \\
\hline M08-16-00-G & 139 & 40.571175 & -67.208496 & 13328.8 & 43406.2 \\
\hline M08-16-00-H & 139 & 40.571671 & -67.199997 & 13328.4 & 43406.3 \\
\hline M08-16-00-I & 139 & 40.573669 & -67.209991 & 13328.6 & 43407.2 \\
\hline M08-17-00-BL & 142 & 40.583450 & -67.186935 & 13320.6 & 43409.6 \\
\hline M08-17-00-G & 142 & 40.584000 & -67.187836 & 13320.7 & 43409.8 \\
\hline M08-17-00-H & 142 & 40.582840 & -67.184830 & 13320.3 & 43409.3 \\
\hline M08-17-00-I & 141 & 40.583511 & -67.188171 & 13320.9 & 43409.7 \\
\hline M08-18-00-BL & 139 & 40.558777 & -67.155120 & 13335.7 & 43402.6 \\
\hline M08-18-00-G & 139 & 40.558838 & -67.225021 & 13335.9 & 43402.6 \\
\hline M08-18-00-H & 139 & 40.558174 & -67.223663 & 13335.8 & 43402.4 \\
\hline M08-18-00-I & 139 & 40.559341 & -67.016678 & 13335.3 & 43402.7 \\
\hline
\end{tabular}




\begin{tabular}{|c|c|c|c|c|c|}
\hline $\begin{array}{l}\text { FIELD } \\
\text { NUMBER } \\
\end{array}$ & $\begin{array}{l}\text { DEPTH, } \\
\text { METERS } \\
\end{array}$ & $\begin{array}{c}\text { LATITUDE, } \\
\text { DEGREES }\end{array}$ & $\begin{array}{c}\text { LONGITUDE, } \\
\text { DEGREES }\end{array}$ & $\begin{array}{c}\text { Tl, } \\
\mu \text { SECONDS }\end{array}$ & $\begin{array}{c}\mathrm{T4}, \\
\mu \mathrm{SECONDS} \\
\end{array}$ \\
\hline OC122-36 & 134 & 40.572670 & -67.20767 & 13328.3 & 43406.6 \\
\hline $0 C 122-37$ & 143 & 40.558174 & -67.22400 & 13335.9 & 43402.6 \\
\hline $0 \mathrm{C} 122-62$ & 79 & 40.659164 & -67.77049 & 13449.2 & 43455.4 \\
\hline $0 C 122-63$ & 79 & 40.659164 & -67.77884 & 13451.4 & 43455.7 \\
\hline $0 \mathrm{C} 122-64$ & 79 & 40.659836 & -67.76482 & 13447.6 & 43455.4 \\
\hline $0 \mathrm{C} 130-2$ & 160 & 40.538170 & -67.72083 & 13465.6 & 43412.0 \\
\hline $0 C 130-3 A$ & 75 & 40.717331 & $-67 \cdot 76317$ & 13433.0 & 43475.8 \\
\hline $0 C 130-3 B$ & 75 & 40.719833 & -67.76102 & 13431.8 & 43475.8 \\
\hline $0 \mathrm{C} 130-3 \mathrm{C}$ & 75 & 40.720840 & -67.76102 & 13431.6 & 43476.2 \\
\hline $0 C 130-4 A$ & 86 & 40.604172 & -67.06950 & $13462 \cdot 3$ & 43436.4 \\
\hline $0 \mathrm{C} 130-4 \mathrm{~B}$ & 86 & 40.602509 & -67.06868 & 13462.5 & 43436.8 \\
\hline M09-19-00-G & 108 & 41.220177 & $-68 \cdot 92082$ & 13630.5 & 43408.7 \\
\hline M09-19-00-H & 108 & 41.218178 & -68.91833 & 13630.5 & 43408.7 \\
\hline M09-20-00-I & 95 & 40.917999 & $-68 \cdot 27400$ & 13520.5 & 43451.5 \\
\hline M09-21-00-I & 88 & 40.810509 & -68.04268 & 13484.2 & 43456.0 \\
\hline
\end{tabular}




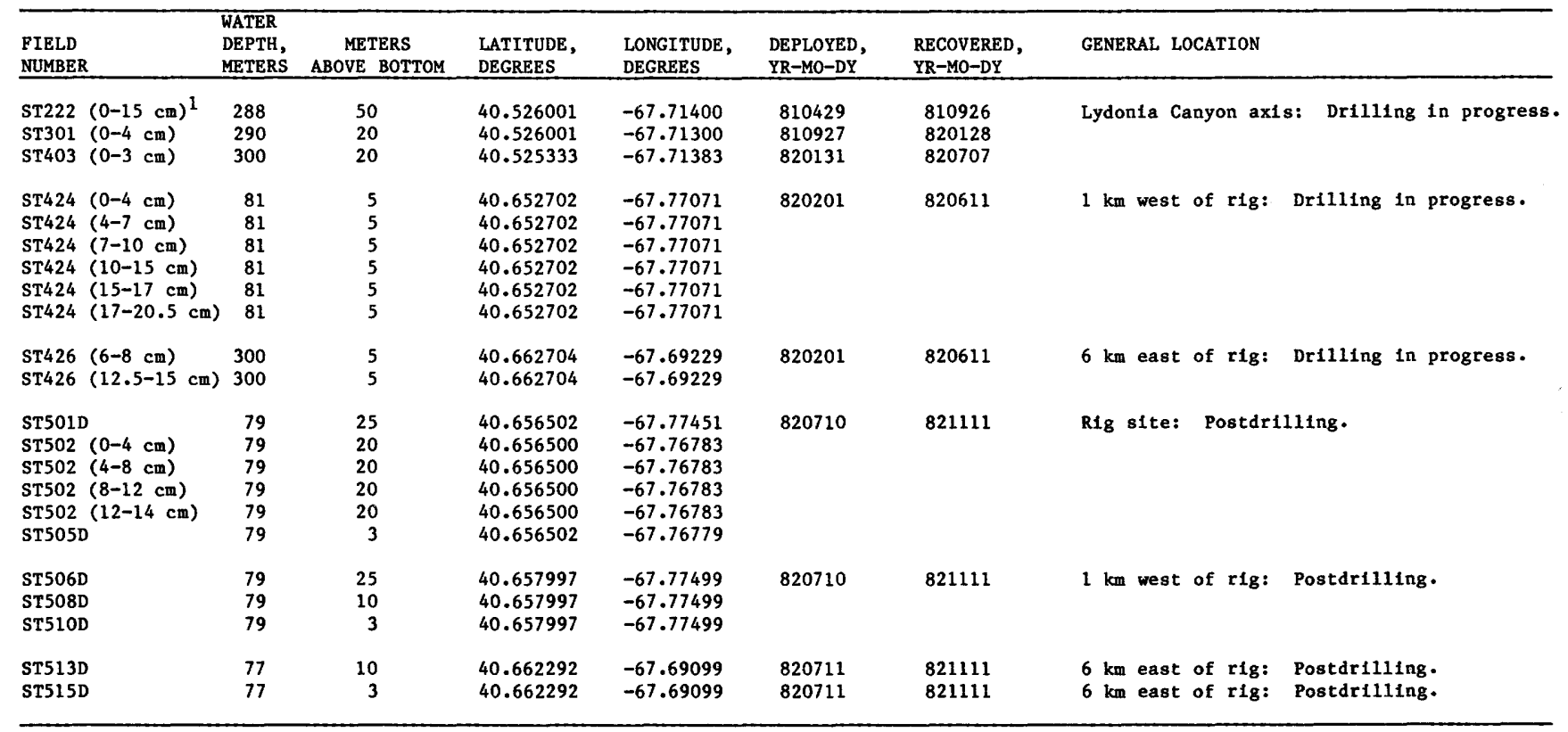

10-15 cm=depth range sampled within collection tube of sediment trap. 
[Values are accurate to two significant figures]

\begin{tabular}{|c|c|c|c|c|c|c|c|c|c|c|c|c|c|c|}
\hline $\begin{array}{l}\text { FIELD } \\
\text { NUMBER }\end{array}$ & $\begin{array}{l}\text { LAB } \\
\text { NUMBER }\end{array}$ & $\begin{array}{l}\text { A1, } \\
\%\end{array}$ & $\begin{array}{l}\mathrm{Ba}, \\
\text { PPM }\end{array}$ & $\begin{array}{l}\text { Cd, } \\
\text { PPM }\end{array}$ & $\begin{array}{l}\text { Cr, } \\
\text { PPM }\end{array}$ & $\begin{array}{l}\text { Cu, } \\
\text { PPM }\end{array}$ & $\begin{array}{l}\mathrm{Hg}, \\
\mathrm{PPM}\end{array}$ & $\begin{array}{c}\mathrm{Fe}, \\
\%\end{array}$ & $\begin{array}{l}\text { Mn, } \\
\text { PPM }\end{array}$ & $\begin{array}{l}\text { N1, } \\
\text { PPM }\end{array}$ & $\begin{array}{l}\mathrm{Pb}, \\
\mathrm{PPM}\end{array}$ & $\begin{array}{l}\text { P, } \\
\text { PPM }\end{array}$ & $\begin{array}{l}\mathrm{Zn}, \\
\mathrm{PPM}\end{array}$ & $\begin{array}{l}\text { BLIND } \\
\text { NUMBER } \\
\end{array}$ \\
\hline $\mathrm{M} 04-02-00-\mathrm{S} 0$ & W-221282 & 0.27 & 83 & $<0.02$ & $<2.0$ & $<1.0$ & 0.0065 & 0.11 & 110 & $<2.0$ & 2.7 & $<2.0$ & 5.0 & - \\
\hline M04-02-00-S0 & W-221283 & .27 & 65 & $<.02$ & $<2.0$ & $<1.0$ & .01 & .11 & 110 & $<2,0$ & 2.7 & $<2.0$ & 2.9 & Blind 45 \\
\hline $\mathrm{M} 04-02-00-\mathrm{S} 0$ & W-221284 & .27 & 55 & $<.02$ & $<2.0$ & $<1.0$ & .01 & .11 & 110 & $<2.0$ & 3.0 & $<2.0$ & 3.3 & Blind 46 \\
\hline M05-02-00-BL & $\mathrm{W}-219030$ & .26 & 38 & $<.02$ & 2.5 & 1.2 & - & .10 & 81 & $<2.0$ & 1.1 & 6.5 & 4.6 & - \\
\hline M05-02-00-BL & W-219056 & .26 & 35 & $<.02$ & 4.0 & $<1.0$ & -- & .11 & 80 & $<2.0$ & 1.6 & 5.5 & 4.2 & Bl1nd31 \\
\hline M05-02-00-BL & W-219057 & .26 & 36 & $<.02$ & 3.0 & $<1.0$ & - & .11 & 82 & $<2.0$ & 1.6 & 6.0 & 3.7 & B1ind 32 \\
\hline M05-05-01-BL & W-218995 & .27 & 120 & $<.02$ & 7.0 & $<1.0$ & - & .43 & 320 & 2.7 & 2.7 & 13.0 & 4.7 & -- \\
\hline M05-05-01-BL & W-219024 & .28 & 120 & $<.02$ & 6.5 & $<1.0$ & -- & .44 & 320 & 2.7 & 3.1 & 13.0 & 5.3 & Blind 33 \\
\hline M05-05-01-BL & W-219025 & .28 & 120 & $<.02$ & 6.0 & $<1.0$ & -- & .43 & 330 & 2.8 & 2.9 & 16.0 & 5.2 & Blind 34 \\
\hline M06-01-00-BL & W-219653 & .79 & 120 & $<.02$ & 5.0 & 1.7 & - & .41 & 93 & $<2.0$ & 5.3 & 7.0 & 7.8 & - \\
\hline M06-01-00-BL & W-219685 & .78 & 130 & $<.02$ & 6.0 & 1.5 & - & .39 & 95 & $<2.0$ & 5.4 & 12.0 & 5.1 & B1ind37 \\
\hline M06-05-01-BL & W-219697 & .29 & 85 & $<.02$ & 6.3 & $<1.0$ & - & .41 & 260 & $<2.0$ & 7.4 & 10.0 & 6.8 & -- \\
\hline M06-05-01-BL & W-219719 & .29 & 83 & $<.02$ & 6.3 & $<1.0$ & -- & .40 & 260 & $<2.0$ & 8.8 & 11.0 & 5.8 & Blind35 \\
\hline M06-05-29-BL & W-219718 & .92 & 130 & $<.02$ & 14.0 & $<1.0$ & -- & .78 & 150 & $<2.0$ & 15.0 & 22.0 & 7.1 & -- \\
\hline M06-05-29-BL & $\mathrm{W}-219720$ & .92 & 130 & $<.02$ & 14.0 & $<1.0$ & -- & .79 & 150 & $<2.0$ & 11.0 & 22.0 & 7.1 & Blind36 \\
\hline M06-18-00-BL & $\mathrm{W}-219682$ & .31 & 66 & .03 & 4.0 & $<1.0$ & -- & .17 & 72 & $<2.0$ & 4.0 & 3.4 & 5.6 & - \\
\hline M06-18-00-BL & W-219686 & .32 & 61 & $<.02$ & $<2.0$ & 1.2 & - & .16 & 78 & $<2.0$ & 5.7 & 4.5 & 5.7 & Blind38 \\
\hline M07-05-01-BL & W-219914 & .32 & 120 & $<.02$ & 6.9 & $<1.0$ & - & .42 & 330 & $<2.0$ & 5.9 & 14.0 & 7.2 & - \\
\hline M07-05-01-BL & W-219926 & .32 & 120 & $<.02$ & 7.4 & $<1.0$ & - & .43 & 330 & $<2.0$ & 5.9 & 12.0 & 6.8 & B1Ind 40 \\
\hline M07-16-00-BL & $W-219876$ & .27 & 62 & $<.02$ & $<2.0$ & $<1.0$ & - & .15 & 84 & $<2.0$ & 2.8 & $<2.0$ & 3.7 & -- \\
\hline $\mathrm{M} 07-16-00-\mathrm{BL}$ & W-219884 & .27 & 62 & $<.02$ & $<2.0$ & $<1.0$ & -- & .14 & 85 & $<2.0$ & 3.08 & $<2.0$ & 3.7 & Blind39 \\
\hline M08-05-01-BL & $\mathrm{W}-220505$ & .31 & 110 & $<.02$ & 6.2 & 1.2 & - & .46 & 270 & $<2.0$ & 4.1 & 19.0 & 8.6 & - \\
\hline M08-05-01-BL & W-220524 & .32 & 100 & $<.02$ & 6.2 & $<1.0$ & - & .47 & 270 & $<2.0$ & 2.9 & 18.0 & 10.0 & Blind 43 \\
\hline M08-05-01-BL & W-220525 & .32 & 110 & $<.02$ & 6.2 & $<1.0$ & - & .47 & 270 & $<2.0$ & 4.6 & 16.0 & 8.1 & Blind 44 \\
\hline M08-16-00-BL & W-220624 & .32 & 63 & $<.02$ & $<2.0$ & $<1.0$ & -- & .16 & 63 & $<2.0$ & 5.6 & $<2.0$ & 7.5 & - \\
\hline M08-16-00-BL & W-220633 & .32 & 59 & $<.02$ & $<2.0$ & $<1.0$ & - & .15 & 66 & $<2.0$ & 3.7 & $<2,0$ & 7.1 & Blind41 \\
\hline M08-16-00-BL & W-220634 & .32 & 59 & $<.02$ & $<2.0$ & $<1.0$ & -- & .15 & 68 & $<2.0$ & 3.7 & $<2.0$ & 7.1 & Blind 42 \\
\hline ST403-0-20 & $\mathrm{W}-221250$ & 3.30 & 260 & .15 & 53.0 & 16.0 & .04 & 2.00 & 270 & 22.0 & 26.0 & 48.0 & 51.0 & - \\
\hline ST403-0-20 & W-221285 & 3.20 & 260 & .09 & 40.0 & 14.0 & .03 & 1.90 & 240 & 18.0 & 26.0 & 44.0 & 46.0 & B1ind 47 \\
\hline ST403-0-20 & W-221286 & 3.20 & 250 & .07 & 38.0 & 13.0 & .03 & 1.90 & 240 & 17.0 & 26.0 & 44.0 & 46.0 & Blind 48 \\
\hline
\end{tabular}


[Values are accurate to two significant figures]

\begin{tabular}{|c|c|c|c|c|c|c|c|c|c|c|c|c|}
\hline $\begin{array}{l}\text { FIELD } \\
\text { NUMBER } \\
\end{array}$ & $\begin{array}{c}\text { GRAVEL, } \\
\% \\
\end{array}$ & $\begin{array}{c}\text { SAND, } \\
\%\end{array}$ & $\begin{array}{c}\text { SILT, } \\
\%\end{array}$ & $\begin{array}{c}\text { CLAY, } \\
\%\end{array}$ & $\begin{array}{c}\text { MEAN, } \\
\phi\end{array}$ & $\begin{array}{c}\text { MEDIAN, } \\
\phi\end{array}$ & $\begin{array}{c}\text { STAND. } \\
\text { DEV., } \\
\phi\end{array}$ & $\begin{array}{c}\text { VERY } \\
\text { COARSE } \\
\text { SAND, } \\
\% \\
\end{array}$ & $\begin{array}{c}\text { COARSE } \\
\text { SAND, } \\
\%\end{array}$ & $\begin{array}{c}\text { MEDIUM } \\
\text { SAND, } \\
\%\end{array}$ & $\begin{array}{c}\text { FINE } \\
\text { SAND, } \\
\% \\
\end{array}$ & $\begin{array}{c}\text { VERY } \\
\text { F INE } \\
\text { SAND } \\
\% \\
\end{array}$ \\
\hline M05-01-00-BL & 0.00 & 99.88 & 0.06 & 0.06 & 3.21 & 3.29 & 0.40 & 0.00 & 0.00 & 0.00 & 29.96 & 69.92 \\
\hline M05-02-00-BL & 0.00 & 99.88 & .08 & .03 & 1.31 & 1.36 & .60 & 2.00 & 25.97 & 61.93 & 9.98 & 0.00 \\
\hline M05-02-00-G & 0.00 & 99.76 & .18 & .06 & 1.61 & 1.57 & .53 & 0.00 & 9.98 & 69.83 & 19.95 & 0.00 \\
\hline M05-02-00-H & 0.00 & 99.75 & .18 & .07 & 1.18 & 1.19 & .66 & 1.99 & 37.91 & 51.87 & 7.98 & 0.00 \\
\hline M05-02-00-I & 0.00 & 99.88 & .09 & .03 & 1.44 & 1.45 & .57 & 0.00 & 21.97 & 62.93 & 14.98 & 0.00 \\
\hline M05-03-00-BL & 4.25 & 93.61 & 1.60 & .55 & 2.08 & 2.09 & 1.22 & 0.00 & 1.87 & 40.25 & 42.12 & 9.37 \\
\hline M05-04-00-BL & 0.00 & 99.71 & .19 & .11 & 2.89 & 2.83 & .51 & 0.00 & 0.00 & 1.99 & 57.83 & 39.89 \\
\hline M05-04-00-G & 0.00 & 99.71 & .18 & .11 & 2.56 & 2.53 & .37 & 0.00 & 0.00 & 4.99 & 84.75 & 9.97 \\
\hline M05-04-00-H & 0.00 & 99.71 & .20 & .09 & 2.56 & 2.53 & .37 & 0.00 & 0.00 & 4.99 & 84.75 & 9.97 \\
\hline$M 05-04-00-I$ & 0.00 & 99.74 & .17 & .09 & 2.57 & 2.53 & .28 & 0.00 & 0.00 & 1.99 & 89.77 & 7.98 \\
\hline M05-05-00-BL & 2.17 & 96.72 & .84 & .26 & 1.09 & .99 & .97 & 1.94 & 46.42 & 38.69 & 9.67 & 0.00 \\
\hline M05-05-00-G & 0.00 & 99.00 & .76 & .24 & .89 & .74 & .94 & 9.90 & 54.45 & 26.73 & 7.92 & 0.00 \\
\hline MO5-05-00-H & 2.56 & 96.88 & .40 & .16 & .90 & .80 & .88 & 4.85 & 53.28 & 31.00 & 7.75 & 0.00 \\
\hline M05-05-00-I & 1.33 & 97.27 & 1.07 & .33 & 1.15 & 1.00 & .97 & 0.00 & 48.63 & 38.91 & 9.73 & 0.00 \\
\hline M05-05-02-BL & 3.32 & 95.72 & .79 & .17 & .90 & .82 & 1.00 & 7.66 & 47.86 & 32.54 & 7.66 & 0.00 \\
\hline M05-05-03-BL & .93 & 98.38 & .55 & .14 & .95 & .82 & .85 & 4.92 & 54.10 & 31.48 & 7.87 & 0.00 \\
\hline M05-05-04-BL & .71 & 98.43 & .70 & .16 & .98 & .85 & .87 & 4.92 & 52.17 & 33.47 & 7.87 & 0.00 \\
\hline M05-05-05-BL & .48 & 99.03 & .39 & .09 & .95 & .82 & .79 & 4.95 & 54.47 & 31.69 & 7.93 & 0.00 \\
\hline M05-05-06-BL & .65 & 98.74 & .50 & .11 & .97 & .90 & .79 & 4.94 & 49.37 & 39.49 & 4.94 & 0.00 \\
\hline M05-05-07-BL & 3.53 & 95.86 & .48 & .13 & .90 & .82 & .92 & 4.79 & 50.81 & 32.59 & 7.67 & 0.00 \\
\hline M05-05-08-BL & 2.31 & 96.93 & .59 & .16 & .87 & .78 & .95 & 9.69 & 48.47 & 31.02 & 7.75 & 0.00 \\
\hline M05-05-09-BL & 1.34 & 97.44 & .95 & .27 & .94 & .80 & 1.03 & 9.74 & 48.72 & 29.24 & 9.74 & 0.00 \\
\hline M05-05-10-BL & 1.22 & 98.03 & .60 & .16 & 1.01 & .90 & .90 & 4.90 & 49.01 & 34.31 & 9.81 & 0.00 \\
\hline M05-05-11-BL & 0.00 & 99.35 & .50 & .15 & 1.04 & 1.01 & .90 & 9.93 & 39.74 & 39.74 & 9.94 & 0.00 \\
\hline M05-05-12-BL & 1.07 & 98.11 & .63 & .19 & 1.18 & 1.12 & .94 & 3.92 & 40.23 & 39.24 & 14.72 & 0.00 \\
\hline M05-05-13-BL & 0.00 & 99.49 & .38 & .13 & 1.65 & 1.59 & .62 & 0.00 & 9.95 & 67.65 & 21.89 & 0.00 \\
\hline M05-05-14-BL & 0.00 & 99.11 & .71 & .18 & 1.01 & .91 & .81 & 3.96 & 50.55 & 39.65 & 4.95 & 0.00 \\
\hline M05-05-15-BL & 2.62 & 96.51 & .70 & .17 & .78 & .70 & .85 & 4.83 & 60.79 & 28.96 & 1.93 & 0.00 \\
\hline M05-05-16-BL & 1.26 & 97.57 & .94 & .24 & .75 & .64 & 1.00 & 14.63 & 53.66 & 23.42 & 5.85 & 0.00 \\
\hline M05-05-17-BL & 3.10 & 95.82 & .84 & .23 & .75 & .64 & 1.02 & 11.50 & 55.58 & 22.04 & 6.71 & 0.00 \\
\hline M05-05-18-BL & .72 & 98.52 & .57 & .19 & 1.00 & .82 & .91 & 4.93 & 54.18 & 27.59 & 11.82 & 0.00 \\
\hline M05-05-18-G & .41 & 99.19 & .32 & .08 & .83 & .70 & .79 & 7.93 & 59.51 & 23.81 & 7.93 & 0.00 \\
\hline M05-05-18-H & 1.08 & 98.04 & .66 & .22 & .83 & .73 & .91 & 9.81 & 53.92 & 29.41 & 4.91 & 0.00 \\
\hline M05-05-18-I & .32 & 99.03 & .50 & .15 & .91 & .81 & .83 & 7.93 & 51.49 & 33.67 & 5.94 & 0.00 \\
\hline M05-05-19-BL & 3.35 & 95.86 & .61 & .18 & 1.09 & 1.08 & .94 & 1.92 & 41.22 & 43.14 & 9. & 0.00 \\
\hline M05-05-20-BL & .74 & 98.80 & .34 & .12 & 1.14 & 1.11 & .78 & 1.98 & 42.48 & 44.47 & 9.88 & 0.00 \\
\hline M05-05-21-BL & .73 & 98.69 & .46 & .11 & 1.04 & 1.00 & .82 & 4.94 & 44.41 & 41.45 & 7.90 & 0.00 \\
\hline M05-05-22-BL & 0.00 & 99.19 & .66 & .15 & .88 & .73 & .78 & 3.97 & 63.48 & & & 0.00 \\
\hline M05-05-23-BL & .91 & 98.18 & .70 & .21 & 1.03 & .90 & .93 & 4.91 & 49.09 & 34.36 & 9.82 & 0.00 \\
\hline M05-05-24-BL & 0.00 & 99.52 & .35 & .13 & 1.75 & 1.69 & .66 & 0.00 & 9.95 & 57.72 & 31.85 & 0.00 \\
\hline M05-05-25-BL & 0.00 & 99.08 & .67 & .25 & 1.33 & 1.26 & .92 & 1.98 & 37.65 & 39.63 & 19.82 & 0.00 \\
\hline$M 05-05-26-R I$ & 2.27 & 95.70 & 1.54 & .49 & .93 & .77 & 1.19 & 9.57 & 49.76 & 28.71 & 7.66 & 0.00 \\
\hline M05-05-27-BL & 0.00 & 99.58 & .31 & .11 & 1.32 & 1.34 & .65 & 0.00 & 29.87 & 59.75 & 9.96 & 0.00 \\
\hline M05-05-28-BL & 2.24 & 96.80 & .67 & .29 & 1.00 & .99 & .95 & 4.84 & 43.56 & 43.56 & 4.84 & 0.00 \\
\hline M05-05-28-G & 2.50 & & .99 & .22 & .91 & .81 & .95 & 4.82 & 52.95 & 33.70 & 4.82 & 0.00 \\
\hline M05-05-28-H & 3.66 & 95.24 & .90 & .20 & .83 & .78 & .97 & 7.62 & 49.53 & 35.23 & 2.86 & 0.00 \\
\hline M05-05-28-I & 1.14 & 98.33 & .41 & .12 & .79 & .69 & .74 & 4.92 & 63.91 & 26.55 & 2.95 & 0.00 \\
\hline M05-05-29-BL & 4.35 & 92.57 & 2.19 & .89 & 2.17 & 2.19 & 1.31 & 0.00 & 1.85 & & 46.29 & 9.26 \\
\hline M05-05-29-G & 6.85 & 90.50 & 1.89 & .76 & 2.32 & 2.44 & 1.39 & 0.00 & 0.00 & 18.10 & 57.01 & 15.38 \\
\hline M05-05-29-H & 8.77 & 87.77 & 2.53 & .92 & 2.23 & 2.41 & 1.55 & 0.00 & 2.64 & 14.92 & 57.05 & 13.16 \\
\hline M05-05-29-I & 7.58 & 89.93 & 1.84 & .65 & 2.08 & 2.29 & 1.40 & 0.00 & 4.50 & 22.48 & 53.96 & 8.99 \\
\hline M05-06-00-BL & 2.84 & 93.81 & 2.53 & .83 & 2.18 & 2.05 & 1.24 & 0.00 & 0.00 & 45.03 & 39.39 & 9.39 \\
\hline $\mathrm{M} 05-07-\mathrm{A} 0-\mathrm{BL}$ & 0.00 & 67.54 & 26.07 & .39 & 4.32 & 3.71 & 1.66 & 0.00 & 0.00 & 0.00 & 6.75 & 60.79 \\
\hline MO5-07-A0-G & 0.00 & 62.74 & 30.37 & .89 & 4.52 & 3.77 & 1.75 & 0.00 & 0.00 & 0.00 & 6.27 & 56.47 \\
\hline
\end{tabular}




\begin{tabular}{|c|c|c|c|c|c|c|c|c|c|c|c|c|}
\hline $\begin{array}{l}\text { FIELD } \\
\text { NUMBER } \\
\end{array}$ & $\begin{array}{l}\text { RAVEL, } \\
\%\end{array}$ & $\begin{array}{c}\text { SAND, } \\
\% \\
\end{array}$ & $\begin{array}{c}\text { SILT, } \\
\%\end{array}$ & $\begin{array}{c}\text { CLAY, } \\
\% \\
\end{array}$ & $\begin{array}{c}\text { MEAN, } \\
\phi\end{array}$ & $\begin{array}{c}\text { MEDIAN, } \\
\phi \\
\end{array}$ & $\begin{array}{c}\text { STAND. } \\
\text { DEV., } \\
\phi\end{array}$ & $\begin{array}{c}\text { VERY } \\
\text { COARSE } \\
\text { SAND, } \\
\% \\
\end{array}$ & $\begin{array}{c}\text { COARSE } \\
\text { SAND, } \\
\% \\
\end{array}$ & $\begin{array}{c}\text { MEDIUM } \\
\text { SAND, } \\
\%\end{array}$ & $\begin{array}{c}\text { FINE } \\
\text { SAND, } \\
\% \\
\end{array}$ & $\begin{array}{c}\text { VERY } \\
\text { FINE } \\
\text { SAND } \\
\% \\
\end{array}$ \\
\hline 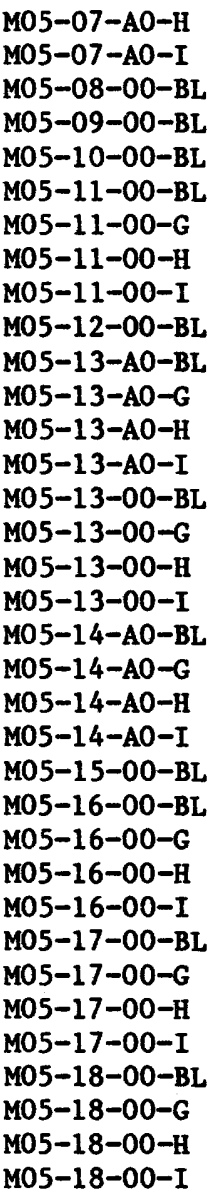 & $\begin{array}{l}0.00 \\
0.00 \\
0.00 \\
0.00 \\
8.11 \\
0.00 \\
0.00 \\
0.00 \\
0.00 \\
.27 \\
0.00 \\
0.00 \\
0.00 \\
0.00 \\
0.00 \\
0.00 \\
0.00 \\
0.00 \\
0.00 \\
0.00 \\
0.00 \\
0.00 \\
0.00 \\
1.51 \\
1.45 \\
.43 \\
3.72 \\
1.54 \\
1.26 \\
1.54 \\
2.21 \\
0.00 \\
.38 \\
0.00 \\
0.00\end{array}$ & $\begin{array}{r}71.37 \\
65.92 \\
97.38 \\
96.81 \\
91.52 \\
97.40 \\
96.94 \\
96.93 \\
98.15 \\
96.04 \\
4.09 \\
3.15 \\
4.72 \\
5.26 \\
57.46 \\
59.73 \\
51.63 \\
49.29 \\
8.71 \\
8.43 \\
10.22 \\
9.23 \\
99.76 \\
97.38 \\
97.14 \\
98.18 \\
95.25 \\
97.91 \\
97.99 \\
97.87 \\
97.51 \\
99.24 \\
98.45 \\
99.22 \\
99.51\end{array}$ & $\begin{array}{r}23.27 \\
28.18 \\
2.00 \\
2.15 \\
.24 \\
1.85 \\
2.18 \\
2.08 \\
1.34 \\
2.81 \\
79.41 \\
83.28 \\
80.75 \\
79.84 \\
35.92 \\
34.78 \\
43.13 \\
43.52 \\
68.48 \\
69.05 \\
67.98 \\
70.35 \\
.16 \\
.78 \\
1.03 \\
.94 \\
.74 \\
.39 \\
.57 \\
.44 \\
.19 \\
.50 \\
.73 \\
.54 \\
.32\end{array}$ & $\begin{array}{r}5.36 \\
5.90 \\
.62 \\
1.04 \\
.13 \\
.76 \\
.88 \\
.99 \\
.51 \\
.88 \\
16.50 \\
13.57 \\
14.53 \\
14.89 \\
6.62 \\
5.50 \\
5.24 \\
7.18 \\
22.81 \\
22.52 \\
21.80 \\
20.42 \\
.08 \\
.32 \\
.38 \\
.45 \\
.29 \\
.16 \\
.18 \\
.15 \\
.08 \\
.26 \\
.45 \\
.24 \\
.17\end{array}$ & $\begin{array}{l}4.14 \\
4.28 \\
1.68 \\
2.55 \\
1.69 \\
3.40 \\
2.98 \\
3.08 \\
3.15 \\
1.68 \\
6.49 \\
6.21 \\
6.20 \\
6.26 \\
4.61 \\
4.48 \\
4.71 \\
4.86 \\
6.51 \\
6.47 \\
6.46 \\
6.39 \\
1.86 \\
.98 \\
.93 \\
.98 \\
1.05 \\
1.17 \\
1.35 \\
1.25 \\
1.01 \\
2.09 \\
2.15 \\
1.99 \\
2.05\end{array}$ & $\begin{array}{l}3.63 \\
3.70 \\
1.59 \\
2.43 \\
2.01 \\
3.39 \\
2.85 \\
2.94 \\
3.18 \\
1.47 \\
6.43 \\
6.01 \\
6.01 \\
6.16 \\
3.83 \\
3.80 \\
3.96 \\
4.06 \\
6.50 \\
6.42 \\
6.46 \\
6.34 \\
1.85 \\
.88 \\
.83 \\
.82 \\
1.08 \\
1.22 \\
1.37 \\
1.31 \\
.98 \\
2.10 \\
2.17 \\
1.92 \\
2.04\end{array}$ & $\begin{array}{r}1.60 \\
1.69 \\
1.09 \\
1.06 \\
1.16 \\
.71 \\
.92 \\
.89 \\
.72 \\
1.30 \\
1.46 \\
1.49 \\
1.55 \\
1.55 \\
1.85 \\
1.72 \\
1.70 \\
1.81 \\
1.77 \\
1.78 \\
1.78 \\
1.75 \\
.63 \\
1.04 \\
1.08 \\
1.05 \\
1.02 \\
.85 \\
.87 \\
.79 \\
.84 \\
.62 \\
.76 \\
.63 \\
.56\end{array}$ & $\begin{array}{r}0.00 \\
0.00 \\
0.00 \\
0.00 \\
0.00 \\
0.00 \\
0.00 \\
0.00 \\
0.00 \\
0.00 \\
0.00 \\
0.00 \\
0.00 \\
0.00 \\
0.00 \\
0.00 \\
0.00 \\
0.00 \\
0.00 \\
0.00 \\
0.00 \\
0.00 \\
2.00 \\
9.74 \\
11.65 \\
7.85 \\
4.76 \\
3.91 \\
1.96 \\
1.96 \\
4.88 \\
0.00 \\
0.00 \\
0.00 \\
0.00\end{array}$ & $\begin{array}{r}0.00 \\
0.00 \\
24.34 \\
0.00 \\
9.15 \\
0.00 \\
0.00 \\
0.00 \\
0.00 \\
28.81 \\
0.00 \\
0.00 \\
0.00 \\
0.00 \\
0.00 \\
0.00 \\
0.00 \\
0.00 \\
0.00 \\
0.00 \\
0.00 \\
0.00 \\
0\end{array}$ & $\begin{array}{r}0.00 \\
0.00 \\
43.82 \\
29.04 \\
32.03 \\
0.00 \\
4.85 \\
0.00 \\
1.96 \\
44.18 \\
0.00 \\
0.00 \\
0.00 \\
0.00 \\
0.00 \\
0.00 \\
0.00 \\
0.00 \\
0.00 \\
0.00 \\
0.00 \\
0.00 \\
\quad 32\end{array}$ & $\begin{array}{r}12.85 \\
13.18 \\
29.22 \\
48.40 \\
50.34 \\
19.48 \\
53.31 \\
53.31 \\
37.30 \\
18.24 \\
0.00 \\
0.00 \\
0.00 \\
0.00 \\
14.36 \\
11.95 \\
7.74 \\
7.39 \\
0.00 \\
0.00 \\
0.00 \\
0.00 \\
41.90 \\
9.74 \\
7.77 \\
7.85 \\
7.62 \\
9.79 \\
15.68 \\
7.83 \\
9.75 \\
54.58 \\
59.07 \\
44.65 \\
51.74\end{array}$ & $\begin{array}{r}58.52 \\
52.74 \\
0.00 \\
19.37 \\
0.00 \\
77.92 \\
38.78 \\
43.62 \\
58.89 \\
4.81 \\
4.09 \\
3.15 \\
4.72 \\
5.26 \\
43.10 \\
47.78 \\
43.89 \\
41.90 \\
8.71 \\
8.43 \\
10.22 \\
9.23 \\
0.00 \\
0.00 \\
0.00 \\
0.00 \\
0.00 \\
0.00 \\
0.00 \\
0.00 \\
0.00 \\
0.00 \\
0.00 \\
0.00 \\
0.00\end{array}$ \\
\hline $\begin{array}{l}\text { M06-01-00-BL } \\
\text { M06-02-00-BL } \\
\text { M06-02-00-G } \\
\text { M06-02-00-H } \\
\text { M06-02-00-I } \\
\text { M06-03-00-BL } \\
\text { M06-04-00-BL } \\
\text { M06-04-00-G } \\
\text { M06-04-00-H } \\
\text { M06-04-00-I } \\
\text { M06-05-00-BL } \\
\text { M06-05-00-G } \\
\text { M06-05-00-H } \\
\text { M06-05-00-I } \\
\text { M06-05-02-BL } \\
\text { M06-05-03-BL } \\
\text { M06-05-04-BL } \\
\text { M06-05-05-BL }\end{array}$ & $\begin{array}{r}0.00 \\
3.27 \\
0.00 \\
3.54 \\
0.00 \\
2.54 \\
0.00 \\
0.00 \\
.75 \\
0.00 \\
2.22 \\
1.39 \\
2.40 \\
1.85 \\
3.83 \\
5.36 \\
.67 \\
1.29\end{array}$ & $\begin{array}{l}99.92 \\
96.58 \\
99.84 \\
96.28 \\
99.64 \\
95.00 \\
99.70 \\
99.69 \\
98.84 \\
99.78 \\
96.98 \\
98.04 \\
97.15 \\
97.01 \\
95.29 \\
93.12 \\
98.86 \\
98.35\end{array}$ & $\begin{array}{r}.04 \\
.11 \\
.11 \\
.12 \\
.27 \\
1.89 \\
.17 \\
.19 \\
.28 \\
.14 \\
.63 \\
.43 \\
.33 \\
.94 \\
.64 \\
1.24 \\
.35 \\
.25\end{array}$ & $\begin{array}{l}.04 \\
.04 \\
.05 \\
.06 \\
.09 \\
.56 \\
.13 \\
.12 \\
.14 \\
.08 \\
.17 \\
.15 \\
.12 \\
.20 \\
.24 \\
.28 \\
.12 \\
.11\end{array}$ & $\begin{array}{r}2.25 \\
1.12 \\
1.56 \\
1.14 \\
1.15 \\
2.20 \\
2.65 \\
2.65 \\
2.62 \\
2.61 \\
.97 \\
1.17 \\
.87 \\
1.38 \\
1.03 \\
.91 \\
1.06 \\
1.19\end{array}$ & $\begin{array}{r}2.33 \\
1.24 \\
1.54 \\
1.24 \\
1.20 \\
2.29 \\
2.58 \\
2.58 \\
2.58 \\
2.56 \\
.89 \\
1.20 \\
.80 \\
1.33 \\
.97 \\
.84 \\
1.00 \\
1.21\end{array}$ & $\begin{array}{r}.37 \\
.84 \\
.57 \\
.82 \\
.74 \\
1.05 \\
.39 \\
.39 \\
.60 \\
.41 \\
.92 \\
.88 \\
.81 \\
1.05 \\
1.03 \\
1.17 \\
.82 \\
.87\end{array}$ & $\begin{array}{l}0.00 \\
4.83 \\
0.00 \\
1.93 \\
4.98 \\
0.00 \\
0.00 \\
0.00 \\
0.00 \\
0.00 \\
4.84 \\
4.90 \\
4.86 \\
1.94 \\
4.76 \\
9.32 \\
4.94 \\
4.92\end{array}$ & $\begin{array}{r}0.00 \\
28.97 \\
14.98 \\
31.77 \\
34.87 \\
1.90 \\
0.00 \\
0.00 \\
0.00 \\
0.00 \\
48.49 \\
34.32 \\
53.43 \\
32.01 \\
42.88 \\
41.90 \\
44.49 \\
34.42\end{array}$ & $\begin{array}{r}24.98 \\
53.12 \\
64.89 \\
52.95 \\
51.82 \\
26.60 \\
1.99 \\
1.99 \\
4.94 \\
4.99 \\
35.89 \\
47.05 \\
34.00 \\
43.66 \\
36.21 \\
32.59 \\
39.54 \\
44.26\end{array}$ & $\begin{array}{r}74.94 \\
9.66 \\
19.97 \\
9.63 \\
7.97 \\
66.50 \\
82.75 \\
82.75 \\
76.10 \\
79.82 \\
7.75 \\
11.77 \\
4.86 \\
15.52 \\
11.43 \\
9.31 \\
9.89 \\
14.75\end{array}$ & $\begin{array}{r}0.00 \\
0.00 \\
0.00 \\
0.00 \\
0.00 \\
0.00 \\
14.96 \\
14.95 \\
17.79 \\
14.97 \\
0.00 \\
0.00 \\
0.00 \\
3.88 \\
0.00 \\
0.00 \\
0.00 \\
0.00\end{array}$ \\
\hline
\end{tabular}




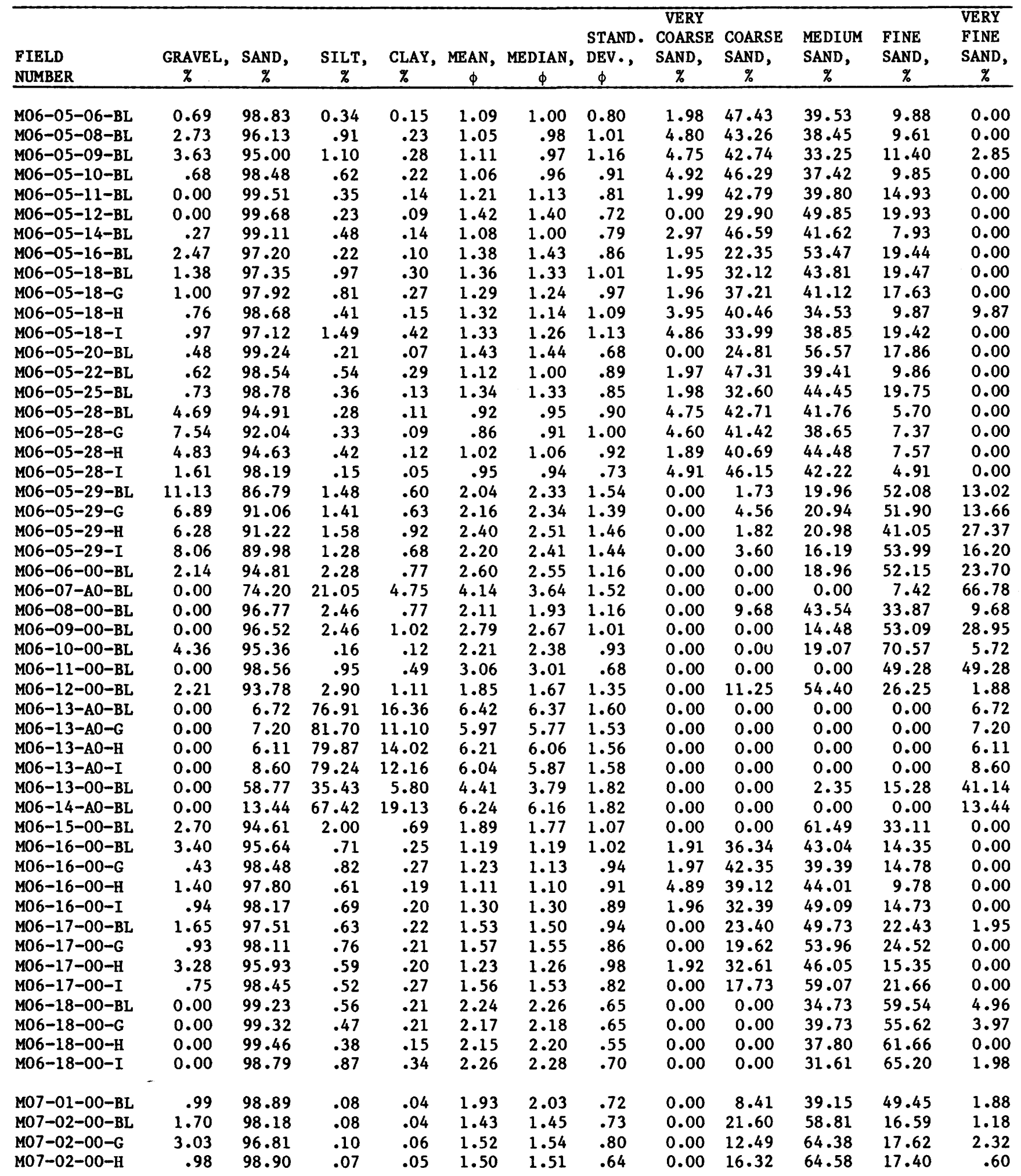




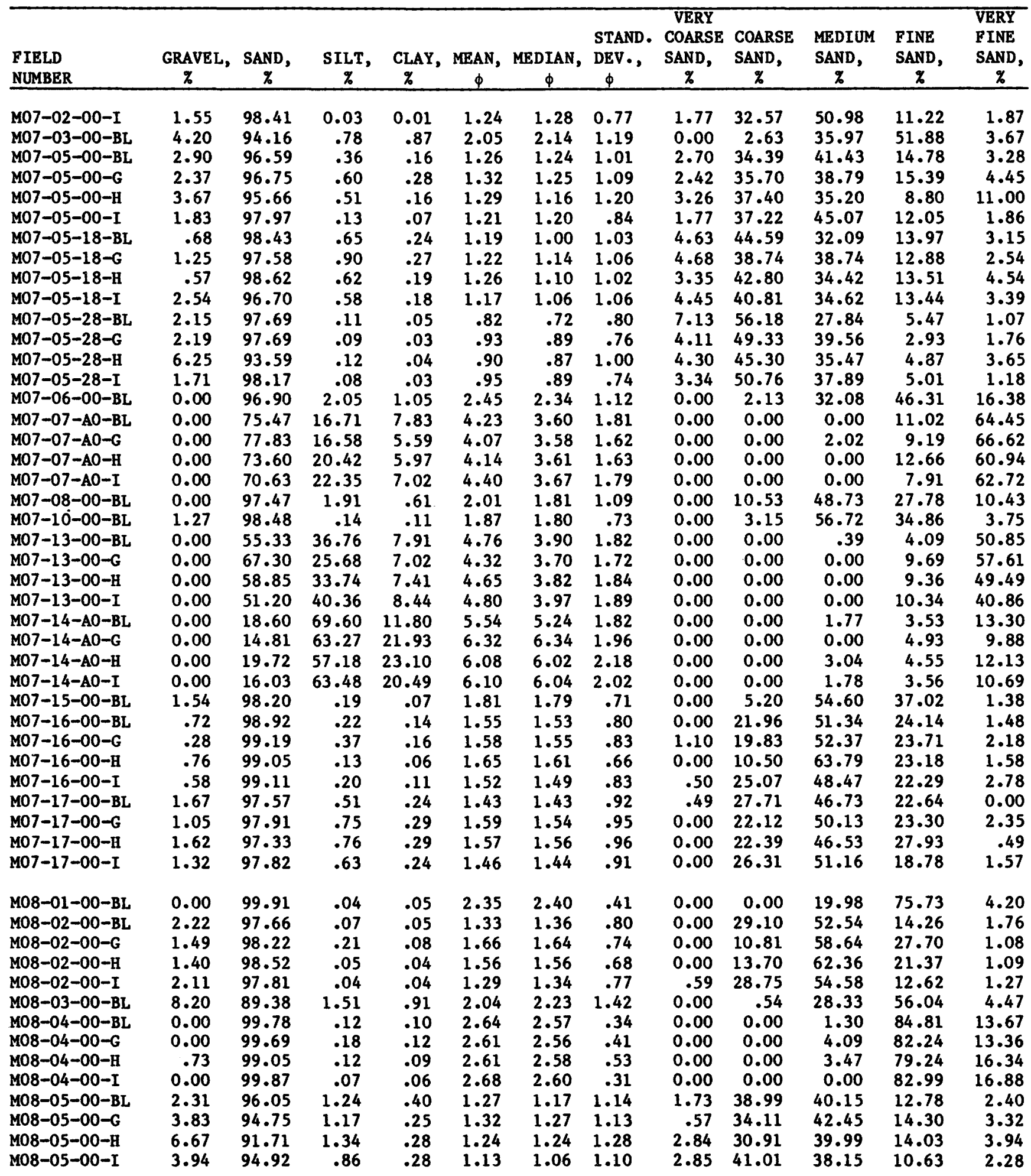




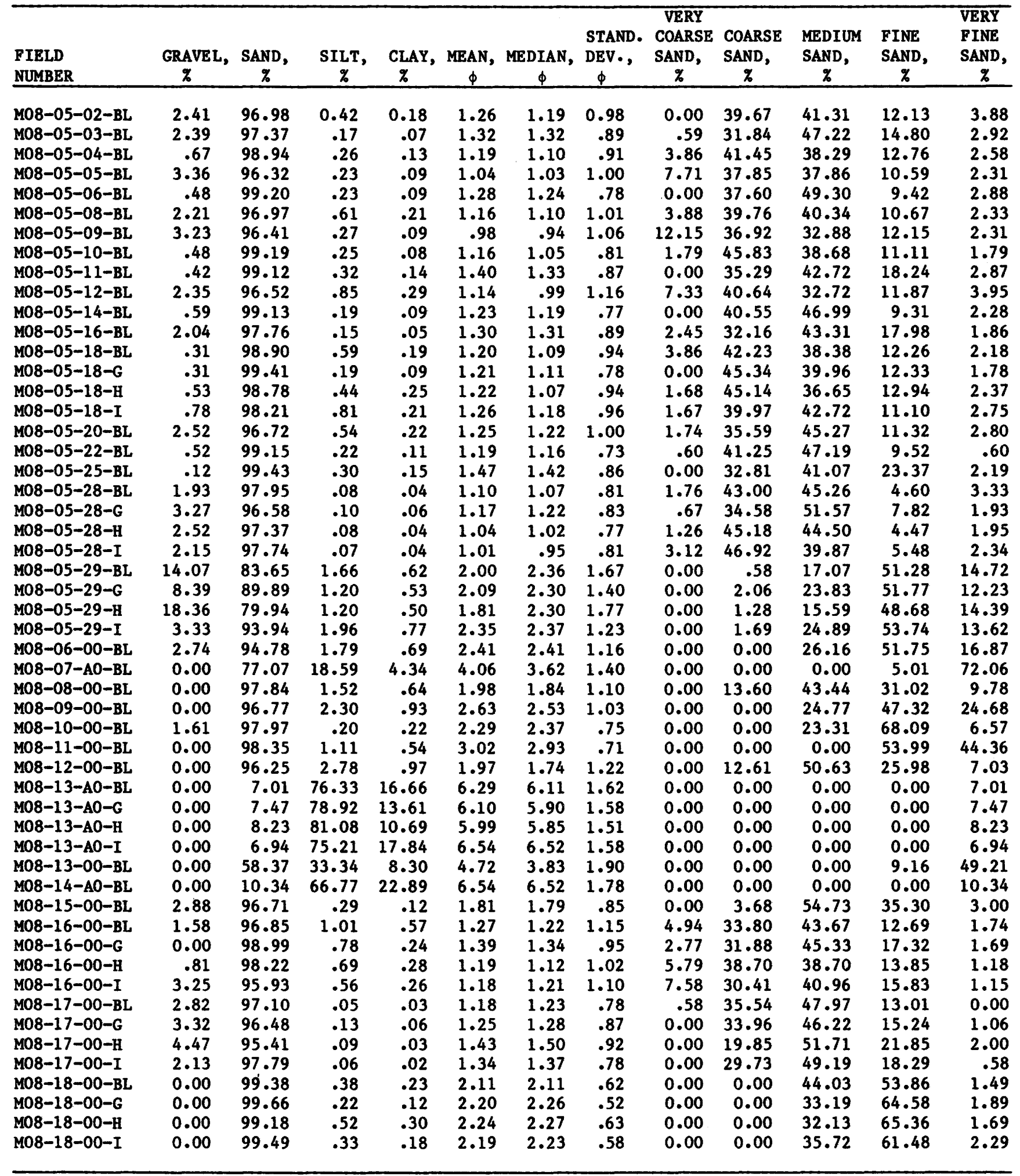




\begin{tabular}{|c|c|c|c|}
\hline SAMPLE & $\begin{array}{c}\text { SEDIMENT } \\
\text { DEPTH, } \\
\text { CM }\end{array}$ & $\begin{array}{c}>60 \mu \mathrm{M}, \\
\%\end{array}$ & $\begin{array}{c}<60 \mu \mathrm{M}, \\
\%\end{array}$ \\
\hline $\begin{array}{l}\text { OC130-2 } \\
\text { OC130-2 } \\
\text { OC130-2 } \\
\text { OC130-2 } \\
\text { OC130-2 } \\
\text { OC130-3BL } \\
\text { OC130-3B } \\
\text { OC130-3C } \\
\text { OC130-4BL } \\
\text { OC130-4A } \\
\text { OC130-4B }\end{array}$ & $\begin{array}{c}0-2 \\
2-4 \\
4-6 \\
6-10 \\
10-13 \\
0-2 \\
2-10 \\
2-10 \\
0-2 \\
2-10 \\
2-10\end{array}$ & $\begin{array}{l}92.3 \\
90.4 \\
90.5 \\
91.5 \\
87.9 \\
99.6 \\
99.8 \\
99.7 \\
97.7 \\
96.8 \\
98.1\end{array}$ & $\begin{array}{r}7.7 \\
9.6 \\
9.5 \\
8.5 \\
12.1 \\
0.4 \\
0.2 \\
0.3 \\
2.3 \\
3.2 \\
1.9\end{array}$ \\
\hline $\begin{array}{l}\text { M9-19G } \\
\text { M9-19G } \\
\text { M9-19G } \\
\text { M9-19G } \\
\text { M9-19G }\end{array}$ & $\begin{array}{l}0-2 \\
2-4 \\
4-6 \\
6-8 \\
8-10\end{array}$ & $\begin{array}{l}95.2 \\
94.6 \\
94.3 \\
94.6 \\
94.7\end{array}$ & $\begin{array}{l}4.8 \\
5.4 \\
5.7 \\
5.4 \\
5.3\end{array}$ \\
\hline $\begin{array}{l}\text { M9-19H } \\
\text { M9-19H } \\
\text { M9-19H } \\
\text { M9-19H }\end{array}$ & $\begin{array}{l}0-2 \\
2-4 \\
4-6 \\
6-8\end{array}$ & $\begin{array}{l}94.4 \\
93.3 \\
95.0 \\
94.6\end{array}$ & $\begin{array}{l}5.6 \\
6.7 \\
5.0 \\
5.4\end{array}$ \\
\hline $\begin{array}{l}\text { M9-20I } \\
\text { M9-20I } \\
\text { M9-20I } \\
\text { M9-20I }\end{array}$ & $\begin{array}{l}0-2 \\
2-4 \\
4-6 \\
6-8\end{array}$ & $\begin{array}{l}98.7 \\
99.4 \\
98.6 \\
98.6\end{array}$ & $\begin{array}{l}1.3 \\
0.6 \\
1.4 \\
1.4\end{array}$ \\
\hline $\begin{array}{l}\text { M9-21I } \\
\text { M9-21I } \\
\text { M9-21I } \\
\text { M9-21I }\end{array}$ & $\begin{array}{l}0-2 \\
2-4 \\
4-6 \\
6-8\end{array}$ & $\begin{array}{l}99.8 \\
99.2 \\
99.2 \\
98.9\end{array}$ & $\begin{array}{l}0.2 \\
0.8 \\
0.8 \\
1.1\end{array}$ \\
\hline $\begin{array}{l}0 C 122-64 \\
\text { oC122-64 } \\
\text { oC122-64 } \\
\text { oC122-64 } \\
\text { oC122-64 } \\
\text { oC122-64 } \\
\text { oC122-64 } \\
\text { oC122-64 }\end{array}$ & $\begin{array}{c}0-1 \\
1-2 \\
2-3 \\
3-4 \\
4-5 \\
5-6 \\
9-10 \\
19-20\end{array}$ & $\begin{array}{l}99.0 \\
99.3 \\
99.1 \\
99.3 \\
99.4 \\
98.2 \\
99.6 \\
99.8\end{array}$ & $\begin{array}{r}1.0 \\
.7 \\
.9 \\
.7 \\
.6 \\
1.8 \\
.4 \\
.2\end{array}$ \\
\hline
\end{tabular}




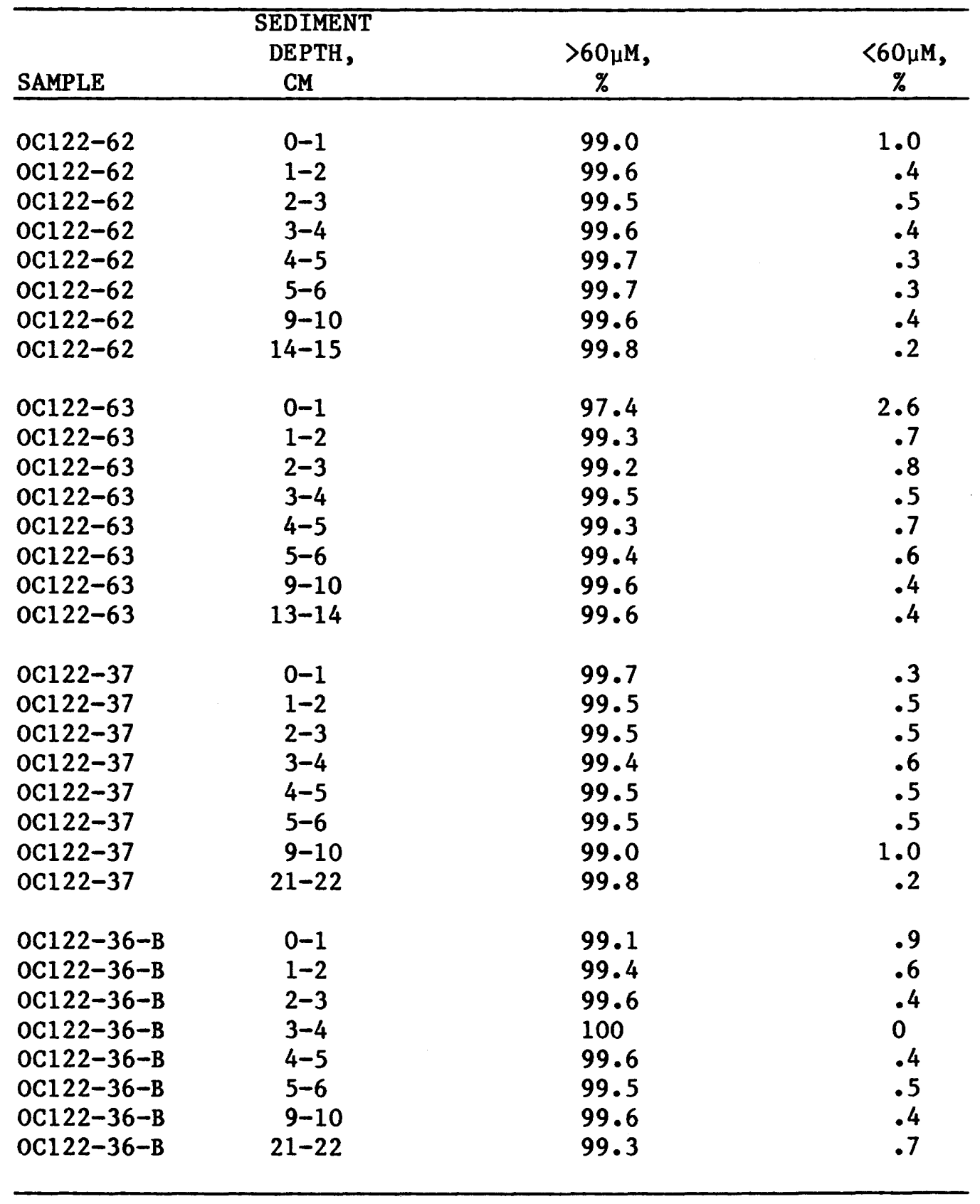




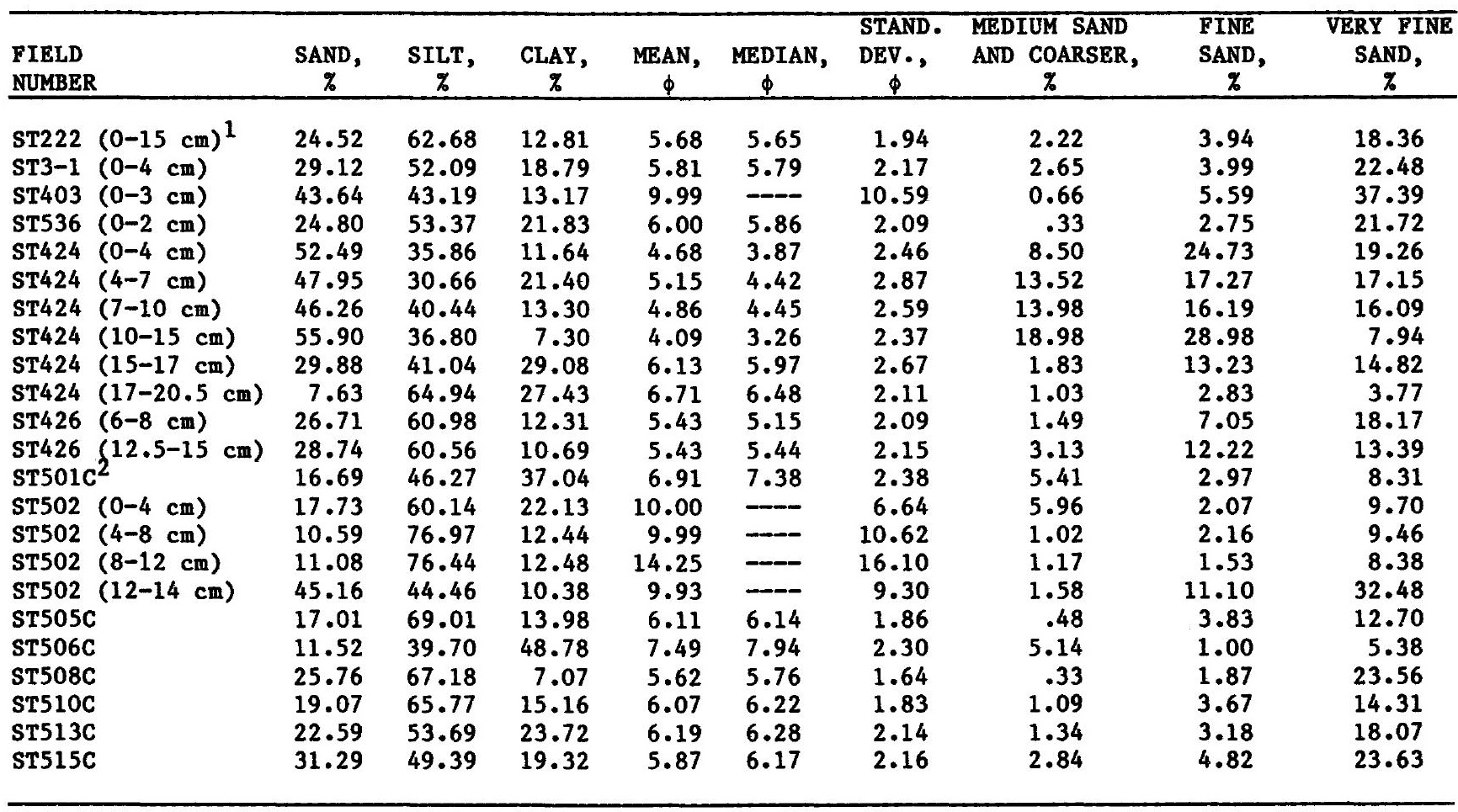

1 0-15 cm=depth range sampled within collection tube of sediment trap.

2 Aliquot of homogenized trap sample. 
[Values are accurate to two significant figures]

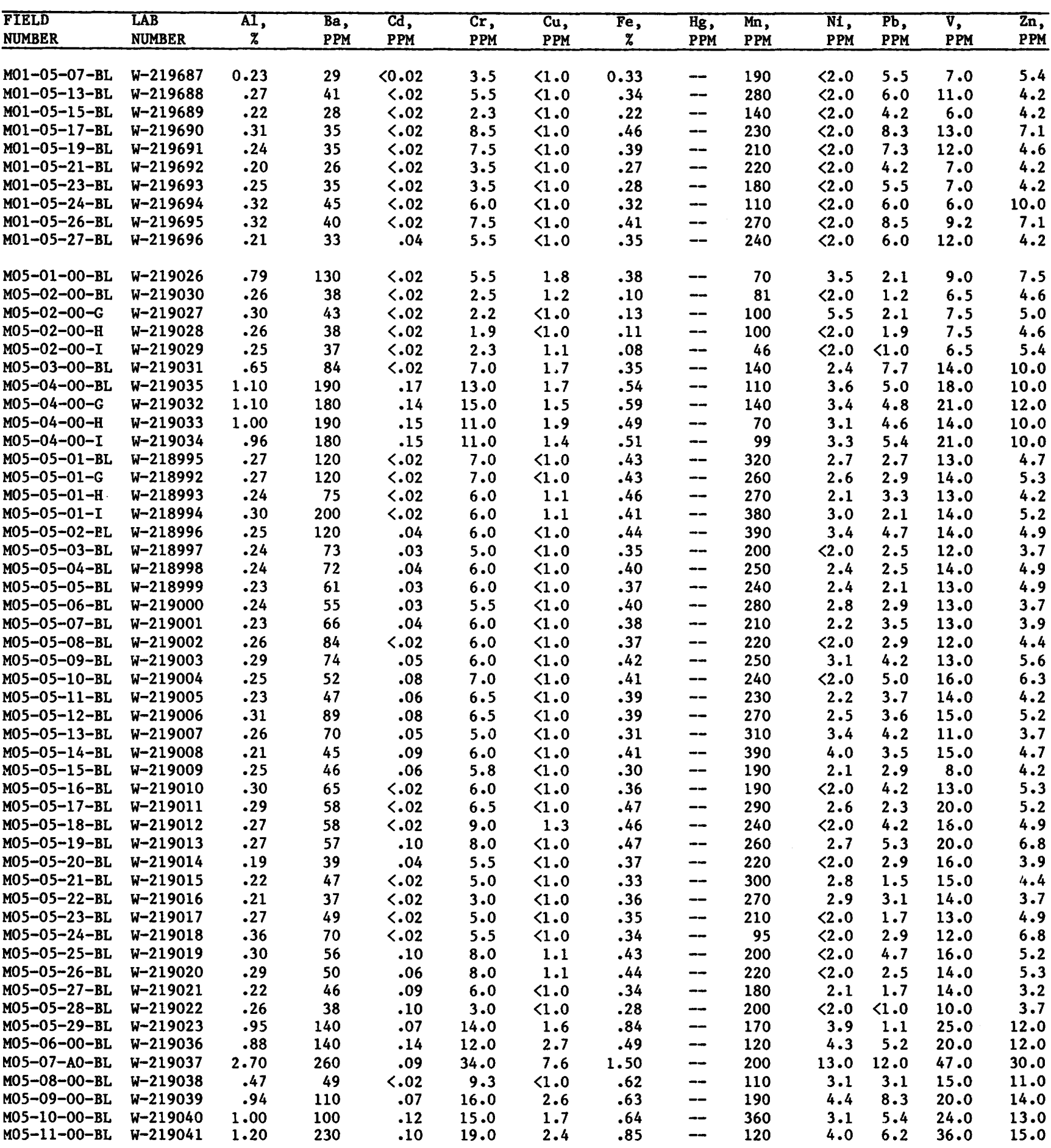


Appendix table 4A.--Chemical analyses of station blends and individual samples--Continued

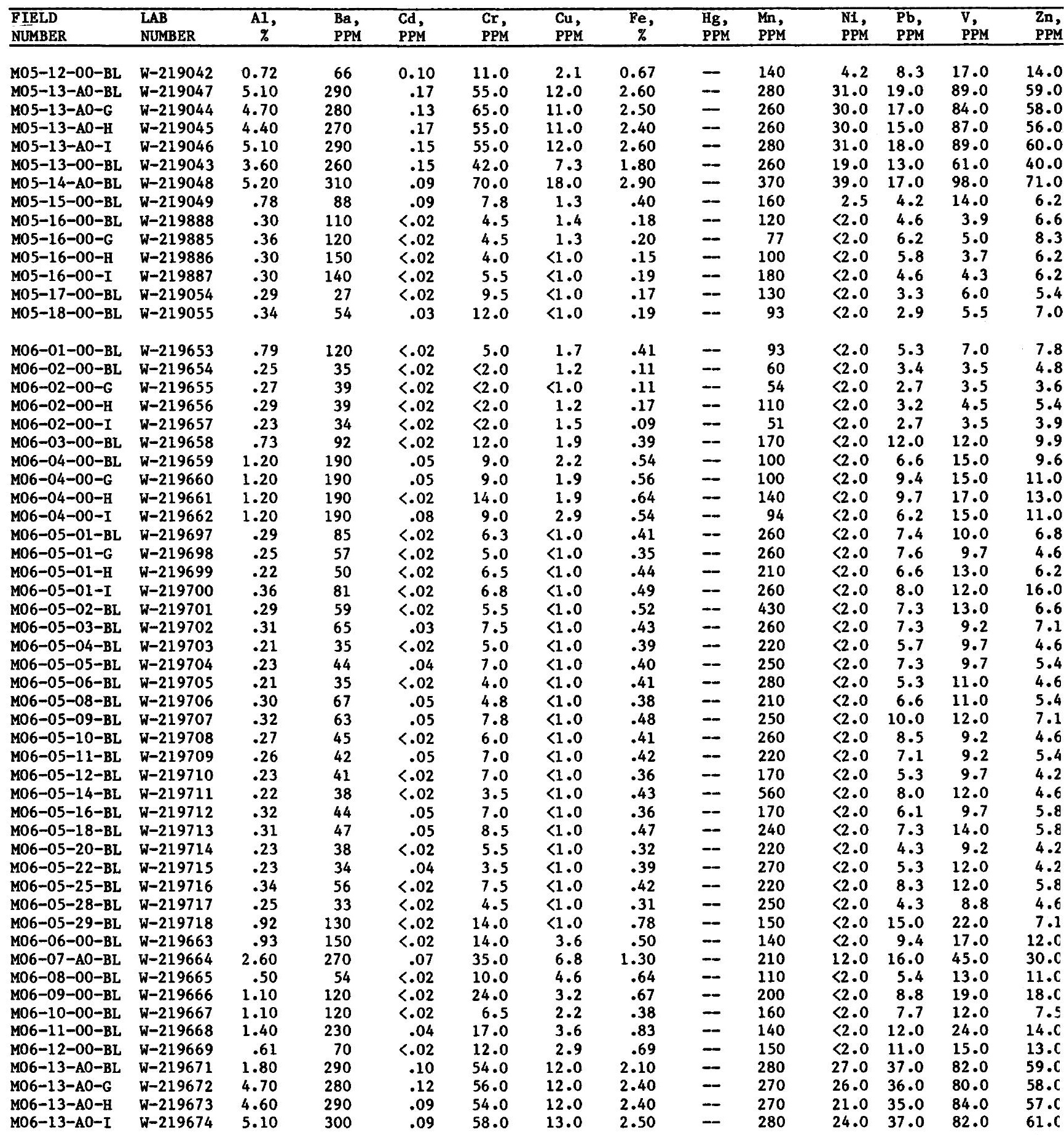




\begin{tabular}{|c|c|c|c|c|c|c|c|c|c|c|c|c|c|}
\hline $\begin{array}{l}\text { IELD } \\
\text { IUMBER } \\
\end{array}$ & $\begin{array}{l}\text { LAB } \\
\text { NUMBER } \\
\end{array}$ & $\begin{array}{c}\mathrm{Al}, \\
\%\end{array}$ & $\begin{array}{l}\mathrm{Ba}, \\
\mathrm{PPM}\end{array}$ & $\begin{array}{l}\text { Cd, } \\
\text { P PM }\end{array}$ & $\begin{array}{l}\mathrm{Cr}, \\
\mathrm{PPM}\end{array}$ & $\begin{array}{l}\mathrm{Cu}, \\
\mathrm{PPM}\end{array}$ & $\begin{array}{c}\mathrm{Fe}, \\
\%\end{array}$ & $\begin{array}{l}\text { Hg, } \\
\text { P PM }\end{array}$ & $\begin{array}{l}\text { Mn, } \\
\text { P PM }\end{array}$ & $\begin{array}{l}\mathrm{N1}, \\
\mathrm{PPM}\end{array}$ & $\begin{array}{l}\mathrm{Pb}, \\
\mathrm{PPM} \\
\end{array}$ & $\begin{array}{l}\text {, } \\
\text { PPM }\end{array}$ & $\begin{array}{l}\mathrm{Zn}, \\
\text { PPM }\end{array}$ \\
\hline $\begin{array}{l}\text { M06-13-00-BL } \\
\text { M06-14-A0-BL } \\
\text { M06-15-00-BL } \\
\text { M06-16-00-BL } \\
\text { M06-16-00-G } \\
\text { M06-16-00-H } \\
\text { M06-16-00-I } \\
\text { M06-17-00-BL } \\
\text { M06-18-00-BL } \\
\text { M06-18-00-G } \\
\text { M06-18-00-H } \\
\text { M06-18-00-I }\end{array}$ & $\begin{array}{l}W-219670 \\
W-219675 \\
W-219676 \\
W-219677 \\
W-219678 \\
W-219679 \\
W-219680 \\
W-219681 \\
W-219682 \\
W-219919 \\
W-219920 \\
W-219921\end{array}$ & $\begin{array}{r}.83 \\
5.20 \\
.73 \\
.28 \\
.30 \\
.34 \\
.27 \\
.28 \\
.31 \\
.28 \\
.29 \\
.28\end{array}$ & $\begin{array}{r}270 \\
310 \\
86 \\
170 \\
230 \\
170 \\
150 \\
43 \\
66 \\
54 \\
42 \\
48\end{array}$ & $\begin{array}{r}0.09 \\
.13 \\
<.02 \\
.03 \\
<.02 \\
<.02 \\
<.02 \\
.04 \\
.03 \\
<.02 \\
<.02 \\
<.02\end{array}$ & $\begin{array}{r}39.0 \\
64.0 \\
2.5 \\
4.0 \\
4.5 \\
4.5 \\
4.0 \\
3.0 \\
4.0 \\
8.8 \\
9.7 \\
8.5\end{array}$ & $\begin{array}{r}7.5 \\
15.0 \\
1.2 \\
<1.0 \\
<1.0 \\
<1.0 \\
<1.0 \\
<1.0 \\
<1.0 \\
<1.0 \\
<1.0 \\
<1.0\end{array}$ & $\begin{array}{r}1.40 \\
2.90 \\
.34 \\
.17 \\
.17 \\
.18 \\
.14 \\
.14 \\
.17 \\
.47 \\
.44 \\
.44\end{array}$ & $\begin{array}{l}-- \\
-- \\
-- \\
-- \\
-- \\
-- \\
-- \\
-- \\
-- \\
-- \\
--\end{array}$ & $\begin{array}{r}260 \\
370 \\
170 \\
100 \\
98 \\
100 \\
110 \\
76 \\
72 \\
320 \\
180 \\
240\end{array}$ & $\begin{array}{r}8.3 \\
31.0 \\
<2.0 \\
<2.0 \\
<2.0 \\
<2.0 \\
<2.0 \\
<2.0 \\
<2.0 \\
<2.0 \\
<2.0 \\
<2.0\end{array}$ & $\begin{array}{r}29.0 \\
33.0 \\
4.8 \\
8.5 \\
8.3 \\
5.8 \\
6.8 \\
3.6 \\
4.0 \\
6.3 \\
6.3 \\
4.9\end{array}$ & $\begin{array}{r}55.0 \\
97.0 \\
13.0 \\
4.3 \\
3.9 \\
4.6 \\
4.1 \\
3.7 \\
3.4 \\
14.0 \\
14.0 \\
13.0\end{array}$ & $\begin{array}{r}38.0 \\
62.0 \\
6.0 \\
8.3 \\
9.1 \\
8.3 \\
7.9 \\
4.2 \\
5.6 \\
6.4 \\
7.2 \\
6.0\end{array}$ \\
\hline 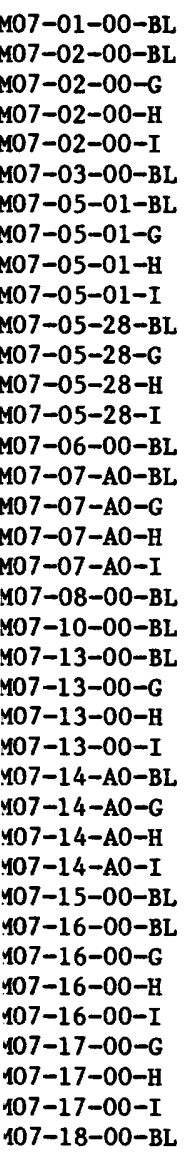 & $\begin{array}{l}W-219854 \\
W-219855 \\
W-219856 \\
W-219857 \\
W-219858 \\
W-219859 \\
W-219914 \\
W-219915 \\
W-219916 \\
W-219917 \\
W-219922 \\
W-219923 \\
W-219924 \\
W-219925 \\
W-219860 \\
W-219861 \\
W-219862 \\
W-219863 \\
W-219864 \\
W-219865 \\
W-219866 \\
W-219867 \\
W-219868 \\
W-219869 \\
W-219870 \\
W-219871 \\
W-219872 \\
W-219873 \\
W-219874 \\
W-219875 \\
W-219876 \\
W-219877 \\
W-219878 \\
W-219879 \\
W-219881 \\
W-219882 \\
W-219883 \\
W-219918\end{array}$ & $\begin{array}{l}.78 \\
.24 \\
.26 \\
.24 \\
.21 \\
.72 \\
.32 \\
.37 \\
.29 \\
.24 \\
.18 \\
.17 \\
.19 \\
.21 \\
.93 \\
2.60 \\
2.60 \\
2.70 \\
2.60 \\
.49 \\
.95 \\
3.50 \\
3.40 \\
3.30 \\
3.70 \\
4.60 \\
4.60 \\
5.00 \\
4.90 \\
.76 \\
.27 \\
.26 \\
.26 \\
.31 \\
.25 \\
.32 \\
.28 \\
.30\end{array}$ & $\begin{array}{r}110 \\
28 \\
28 \\
28 \\
21 \\
85 \\
120 \\
150 \\
88 \\
60 \\
22 \\
22 \\
23 \\
25 \\
130 \\
250 \\
250 \\
250 \\
250 \\
41 \\
85 \\
250 \\
250 \\
250 \\
260 \\
290 \\
300 \\
300 \\
300 \\
77 \\
62 \\
100 \\
44 \\
130 \\
19 \\
27 \\
22 \\
51 \\
\end{array}$ & $\begin{array}{l}<.02 \\
.04 \\
.05 \\
.03 \\
.04 \\
.04 \\
<.02 \\
<.02 \\
<.02 \\
<.02 \\
<.02 \\
<.02 \\
<.02 \\
<.02 \\
.03 \\
.07 \\
.07 \\
.07 \\
.06 \\
<.02 \\
<.02 \\
.04 \\
<.02 \\
.03 \\
.03 \\
.08 \\
.08 \\
.05 \\
<.02 \\
<.02 \\
<.02 \\
<.02 \\
<.02 \\
<.02 \\
<.02 \\
<.02 \\
<.02 \\
<.02\end{array}$ & $\begin{array}{r}4.5 \\
<2.0 \\
<2.0 \\
<2.0 \\
<2.0 \\
<2.0 \\
6.9 \\
7.4 \\
8.8 \\
6.0 \\
4.1 \\
6.9 \\
4.6 \\
4.6 \\
16.0 \\
34.0 \\
32.0 \\
34.0 \\
31.0 \\
3.5 \\
<2.0 \\
30.0 \\
29.0 \\
38.0 \\
32.0 \\
52.0 \\
54.0 \\
52.0 \\
52.0 \\
<2.0 \\
<2.0 \\
<2.0 \\
<2.0 \\
<2.0 \\
<2.0 \\
<2.0 \\
<2.0 \\
9.2\end{array}$ & $\begin{array}{r}<1.0 \\
<1.0 \\
<1.0 \\
<1.0 \\
<1.0 \\
1.2 \\
<1.0 \\
<1.0 \\
<1.0 \\
<1.0 \\
<1.0 \\
<1.0 \\
<1.0 \\
<1.0 \\
1.2 \\
5.3 \\
5.5 \\
5.9 \\
4.8 \\
<1.0 \\
<1.0 \\
5.9 \\
5.0 \\
5.6 \\
9.1 \\
15.0 \\
16.0 \\
15.0 \\
13.0 \\
<1.0 \\
<1.0 \\
<1.0 \\
<1.0 \\
<1.0 \\
<1.0 \\
<1.0 \\
<1.0 \\
1.2\end{array}$ & $\begin{array}{r}.45 \\
.10 \\
.10 \\
.09 \\
.09 \\
.37 \\
.42 \\
.44 \\
.42 \\
.36 \\
.21 \\
.19 \\
.24 \\
.22 \\
.53 \\
1.40 \\
1.40 \\
1.40 \\
1.30 \\
.63 \\
.35 \\
1.70 \\
1.60 \\
1.60 \\
1.80 \\
2.70 \\
2.80 \\
2.70 \\
2.70 \\
.35 \\
.15 \\
.11 \\
.11 \\
.21 \\
.11 \\
.17 \\
.12 \\
.48\end{array}$ & $\begin{array}{l}- \\
- \\
- \\
- \\
- \\
- \\
- \\
- \\
- \\
- \\
- \\
- \\
- \\
- \\
- \\
- \\
- \\
- \\
- \\
- \\
- \\
- \\
- \\
- \\
- \\
- \\
- \\
- \\
- \\
- \\
- \\
- \\
\end{array}$ & $\begin{array}{r}110 \\
69 \\
70 \\
67 \\
59 \\
180 \\
330 \\
400 \\
310 \\
250 \\
110 \\
88 \\
160 \\
84 \\
140 \\
190 \\
180 \\
190 \\
190 \\
100 \\
160 \\
260 \\
250 \\
240 \\
260 \\
370 \\
400 \\
350 \\
350 \\
160 \\
84 \\
84 \\
59 \\
150 \\
73 \\
70 \\
44 \\
270\end{array}$ & $\begin{array}{l}<2.0 \\
<2.0 \\
<2.0 \\
<2.0 \\
<2.0 \\
<2.0 \\
<2.0 \\
<2.0 \\
<2.0 \\
<2.0 \\
<2.0 \\
<2.0 \\
<2.0 \\
<2.0 \\
<2.0 \\
13.0 \\
12.0 \\
14.0 \\
10.0 \\
<2.0 \\
<2.0 \\
11.0 \\
11.0 \\
11.0 \\
12.0 \\
28.0 \\
29.0 \\
31.0 \\
28.0 \\
<2.0 \\
<2.0 \\
<2.0 \\
<2.0 \\
<2.0 \\
<2.0 \\
<2.0 \\
<2.0 \\
<2.0\end{array}$ & $\begin{array}{r}5.0 \\
2.7 \\
2.7 \\
3.1 \\
2.7 \\
9.1 \\
5.9 \\
4.9 \\
5.2 \\
21.0 \\
2.2 \\
2.2 \\
2.6 \\
3.2 \\
9.6 \\
17.0 \\
16.0 \\
22.0 \\
19.0 \\
5.0 \\
4.5 \\
20.0 \\
22.0 \\
23.0 \\
26.0 \\
27.0 \\
26.0 \\
18.0 \\
23.0 \\
3.7 \\
2.8 \\
3.0 \\
2.5 \\
3.5 \\
1.8 \\
4.3 \\
3.0 \\
6.3\end{array}$ & $\begin{array}{r}10.0 \\
<2.0 \\
<2.0 \\
<2.0 \\
<2.0 \\
8.0 \\
14.0 \\
14.0 \\
13.0 \\
10.0 \\
5.8 \\
5.0 \\
6.5 \\
7.3 \\
21.0 \\
51.0 \\
51.0 \\
53.0 \\
47.0 \\
8.0 \\
8.0 \\
59.0 \\
58.0 \\
54.0 \\
69.0 \\
120 \\
120 \\
120 \\
110 \\
8.0 \\
<2.0 \\
<2.0 \\
<2.0 \\
<2.0 \\
<2.0 \\
<2.0 \\
<2.0 \\
14.0\end{array}$ & $\begin{array}{r}6.6 \\
2.1 \\
2.1 \\
2.1 \\
2.1 \\
7.9 \\
7.2 \\
9.2 \\
6.4 \\
5.6 \\
3.6 \\
2.8 \\
2.8 \\
4.0 \\
11.0 \\
29.0 \\
29.0 \\
31.0 \\
27.0 \\
10.0 \\
7.5 \\
40.0 \\
35.0 \\
35.0 \\
40.0 \\
66.0 \\
68.0 \\
69.0 \\
68.0 \\
5.8 \\
3.7 \\
2.9 \\
2.5 \\
6.2 \\
2.5 \\
3.7 \\
3.3 \\
8.0\end{array}$ \\
\hline $\begin{array}{l}108-01-00-\mathrm{BL} \\
108-02-00-\mathrm{BL} \\
108-02-00-\mathrm{G} \\
108-02-00-\mathrm{H} \\
108-02-00-\mathrm{I} \\
108-03-00-\mathrm{BL} \\
108-04-00-\mathrm{BL}\end{array}$ & $\begin{array}{l}W-220597 \\
W-220601 \\
W-220598 \\
W-220599 \\
W-220600 \\
W-220602 \\
W-220606\end{array}$ & $\begin{array}{r}.82 \\
.25 \\
.30 \\
.25 \\
.23 \\
.71 \\
1.20\end{array}$ & $\begin{array}{r}120 \\
29 \\
35 \\
27 \\
24 \\
81 \\
160\end{array}$ & $\begin{array}{l}<.02 \\
<.02 \\
<.02 \\
<.02 \\
<.02 \\
<.02 \\
<.02\end{array}$ & $\begin{array}{r}4.0 \\
<2.0 \\
<2.0 \\
<2.0 \\
<2.0 \\
4.5 \\
14.0\end{array}$ & $\begin{array}{r}<1.0 \\
<1.0 \\
<1.0 \\
<1.0 \\
<1.0 \\
1.7 \\
<1.0\end{array}$ & $\begin{array}{l}.37 \\
.11 \\
.13 \\
.11 \\
.08 \\
.38 \\
.59\end{array}$ & $\begin{array}{l}- \\
-- \\
-- \\
-- \\
-- \\
--\end{array}$ & $\begin{array}{r}56 \\
71 \\
95 \\
83 \\
43 \\
170 \\
140\end{array}$ & $\begin{array}{l}<2.0 \\
<2.0 \\
<2.0 \\
<2.0 \\
<2.0 \\
<2.0 \\
<2.0\end{array}$ & $\begin{array}{r}4.3 \\
2.7 \\
2.7 \\
2.0 \\
2.3 \\
11.0 \\
7.6\end{array}$ & $\begin{array}{r}3.0 \\
<2.0 \\
<2.0 \\
<2.0 \\
<2.0 \\
7.5 \\
9.5\end{array}$ & $\begin{array}{l}5.4 \\
2.9 \\
2.9 \\
2.5 \\
2.1 \\
8.3 \\
9.5\end{array}$ \\
\hline
\end{tabular}




\begin{tabular}{|c|c|c|c|c|c|c|c|c|c|c|c|c|c|}
\hline $\begin{array}{l}\text { FIELD } \\
\text { NUMBER } \\
\end{array}$ & $\begin{array}{l}\text { LAB } \\
\text { NUMBER } \\
\end{array}$ & $\begin{array}{c}\text { A1, } \\
\%\end{array}$ & $\begin{array}{l}\mathrm{Ba}, \\
\mathrm{PPM}\end{array}$ & $\begin{array}{l}\text { Cd, } \\
\text { PPM }\end{array}$ & $\begin{array}{l}\mathrm{Cr}, \\
\mathrm{PPM} \\
\end{array}$ & $\begin{array}{l}\mathrm{Cu}, \\
\text { PPM }\end{array}$ & $\begin{array}{c}\mathrm{Fe}, \\
\%\end{array}$ & $\begin{array}{l}\mathrm{Hg}, \\
\mathrm{PPM}\end{array}$ & $\begin{array}{l}\text { Mn, } \\
\text { PPM }\end{array}$ & $\begin{array}{l}\text { N, } \\
\text { PPM }\end{array}$ & $\begin{array}{l}\mathrm{Pb}, \\
\mathrm{PPM}\end{array}$ & $\begin{array}{l}\text {, } \\
\text { PPM } \\
\end{array}$ & $\begin{array}{l}\mathrm{Zn}, \\
\mathrm{PPM}\end{array}$ \\
\hline M08-04-00-G & W-220603 & 1.20 & 170 & $<0.02$ & 17.0 & $<1.0$ & 0.76 & - & 230 & 2.0 & 11.0 & 15.0 & 12.0 \\
\hline M08-04-00-H & W-220604 & 1.20 & 170 & $<.02$ & 12.0 & $<1.0$ & .56 & - & 120 & $<2.0$ & 8.3 & 9.5 & 8.3 \\
\hline $\mathrm{M08}-05-01-\mathrm{BL}$ & $W-220505$ & .31 & 110 & $<.02$ & 6.2 & 1.2 & .46 & - & 270 & $<2.0$ & 4.1 & 19.0 & 8.6 \\
\hline M08-05-01-G & $W-220502$ & .29 & 80 & $<.02$ & 6.2 & $<1.0$ & .44 & - & 240 & $<2.0$ & 5.1 & 13.0 & 7.5 \\
\hline M08-05-01-H & $\mathrm{W}-220503$ & .38 & 180 & $<.02$ & 7.5 & $<1.0$ & .51 & - & 300 & 2.3 & 6.9 & 14.0 & 8.6 \\
\hline M08-05-01-I & W-220504 & .27 & 72 & $<.02$ & 6.2 & $<1.0$ & .42 & - & 300 & $<2.0$ & 4.9 & 13.0 & 7.5 \\
\hline M08-05-02-BL & $W-220506$ & .22 & 44 & $<.02$ & 6.2 & $<1.0$ & .36 & - & 300 & $<2.0$ & 4.4 & 12.0 & 7.5 \\
\hline M08-05-03-BL & $W-220507$ & .23 & 47 & $<.02$ & 4.9 & $<1.0$ & .34 & - & 210 & $<2.0$ & 5.7 & 13.0 & 5.9 \\
\hline M08-05-04-BL & $W-220508$ & .20 & 31 & $<.02$ & 4.9 & $<1.0$ & .39 & - & 230 & $<2.0$ & 4.9 & 11.0 & 7.0 \\
\hline M08-05-05-BL & $\mathrm{W}-220509$ & .20 & 39 & $<.02$ & 4.9 & $<1.0$ & .39 & -- & 250 & $<2.0$ & 4.4 & 13.0 & 7.0 \\
\hline M08-05-06-BL & W-220510 & .19 & 31 & $<.02$ & 4.9 & $<1.0$ & .33 & - & 260 & $<2.0$ & 3.6 & 12.0 & 5.4 \\
\hline M08-05-08-BL & W-220511 & .24 & 38 & $<.02$ & 4.9 & $<1.0$ & .34 & - & 240 & $<2.0$ & 3.1 & 12.0 & 6.4 \\
\hline M08-05-09-BL & W-220512 & .30 & 53 & $<.02$ & 6.2 & $<1.0$ & .44 & - & 240 & $<2.0$ & 4.6 & 15.0 & 7.5 \\
\hline M08-05-10-BL & W-220513 & .23 & 38 & $<.02$ & 8.8 & $<1.0$ & .40 & -- & 290 & $<2.0$ & 5.6 & 14.0 & 6.4 \\
\hline M08-05-11-BL & W-220514 & .24 & 39 & $<.02$ & 11.0 & $<1.0$ & .39 & - & 200 & $<2.0$ & 4.9 & 13.0 & 6.4 \\
\hline M08-05-12-BL & W-220515 & .27 & 56 & $<.02$ & 7.5 & $<1.0$ & .43 & -- & 280 & $<2.0$ & 4.6 & 14.0 & 7.0 \\
\hline M08-05-14-BL & W-220516 & .19 & 31 & $<.02$ & 3.7 & $<1.0$ & .31 & - & 270 & $<2.0$ & 4.1 & 11.0 & 4.8 \\
\hline M08-05-16-BL & $w-220517$ & .26 & 40 & $<.02$ & 3.7 & $<1.0$ & .27 & - & 150 & $<2.0$ & 4.3 & 8.8 & 5.4 \\
\hline M08-05-18-BL & $W-220518$ & .21 & 33 & $<.02$ & 6.2 & $<1.0$ & .43 & - & 350 & $<2.0$ & 5.4 & 13.0 & 6.4 \\
\hline M08-05-20-BL & W-220519 & .22 & 43 & $<.02$ & 4.9 & $<1.0$ & .34 & - & 250 & $<2.0$ & 4.0 & 11.0 & 5.9 \\
\hline M08-05-22-BL & $W-220520$ & .18 & 30 & $<.02$ & 3.7 & $<1.0$ & .36 & - & 350 & $<2.0$ & 3.4 & 12.0 & 4.8 \\
\hline M08-05-25-BL & W-220521 & .26 & 39 & $<.02$ & 6.2 & $<1.0$ & .40 & - & 230 & $<2.0$ & 5.0 & 11.0 & 7.0 \\
\hline M08-05-28-BL & W-220522 & .20 & 25 & $<.02$ & 2.4 & $<1.0$ & .20 & - & 150 & $<2.0$ & 2.9 & 5.5 & 4.8 \\
\hline M08-05-29-BL & W-220523 & .88 & 130 & $<.02$ & 14.0 & 1.2 & .76 & - & 170 & $<2.0$ & 6.7 & 18.0 & 13.0 \\
\hline M08-06-00-BL & W-220607 & .91 & 130 & $<.02$ & 12.0 & 1.5 & .49 & - & 130 & $<2.0$ & 9.6 & 12.0 & 9.5 \\
\hline M08-07-A0-BL & $W-220608$ & 2.60 & 240 & .06 & 36.0 & 5.8 & 1.30 & -- & 190 & 11.0 & 21.0 & 37.0 & 28.0 \\
\hline M08-08-00-BL & $W-220609$ & .49 & 40 & $<.02$ & 8.5 & 1.1 & .61 & - & 100 & $<2.0$ & 5.8 & 6.3 & 9.5 \\
\hline M08-09-00-BL & W-220610 & 1.00 & 99 & $<.02$ & 19.0 & 1.7 & .69 & - & 220 & $<2.0$ & 9.6 & 15.0 & 14.0 \\
\hline M08-10-00-BL & W-220611 & 1.00 & 100 & $<.02$ & 5.5 & $<1.0$ & .31 & - & 92 & $<2.0$ & 7.6 & 4.0 & 5.8 \\
\hline M08-11-00-BL & $W-220612$ & 1.60 & 210 & $<.02$ & 20.0 & 2.6 & .87 & - & 150 & 2.5 & 13.0 & 20.0 & 13.0 \\
\hline M08-12-00-BL & W-220613 & .76 & 60 & $<.02$ & 11.0 & $<1.0$ & .71 & - & 140 & $<2.0$ & 8.6 & 8.5 & 12.0 \\
\hline MO8-13-A0-BL & W-220618 & 4.80 & 280 & .05 & 54.0 & 11.0 & 2.50 & - & 280 & 24.0 & 31.0 & 75.0 & 61.0 \\
\hline$M 08-13-A 0-G$ & W-220615 & 4.30 & 270 & .05 & 50.0 & 10.0 & 2.50 & - & 280 & 25.0 & 27.0 & 82.0 & 60.0 \\
\hline M08-13-A0-H & W-220616 & 3.80 & 280 & .05 & 53.0 & 9.6 & 2.30 & - & 270 & 26.0 & 34.0 & 66.0 & 59.0 \\
\hline M08-13-A0-I & W-220617 & 4.40 & 280 & .06 & 58.0 & 11.0 & 2.50 & - & 270 & 31.0 & 32.0 & 81.0 & 62.0 \\
\hline M08-13-00-BL & W-220614 & 2.80 & 240 & .05 & 40.0 & 7.6 & 1.60 & - & 260 & 22.0 & 22.0 & 48.0 & 38.0 \\
\hline M08-14-A0-BL & W-220619 & 5.00 & 300 & .05 & 62.0 & 19.0 & 2.90 & - & 350 & 33.0 & 27.0 & 91.0 & 73.0 \\
\hline M08-15-00-BL & W-220620 & .78 & 77 & $<.02$ & 11.0 & $<1.0$ & .49 & - & 240 & $<2.0$ & 4.0 & 9.5 & 8.3 \\
\hline M08-16-00-BL & W-220624 & .32 & 63 & $<.02$ & $<2.0$ & $<1.0$ & .16 & - & 63 & $<2.0$ & 5.6 & $<2.0$ & 7.5 \\
\hline$M 08-16-00-G$ & W-220621 & .27 & 43 & $<.02$ & 2.5 & $<1.0$ & .14 & - & 54 & $<2.0$ & 3.7 & $<2.0$ & 4.2 \\
\hline M08-16-00-H & W-220622 & .29 & 140 & $<.02$ & $<2.0$ & $<1.0$ & .16 & - & 83 & $<2.0$ & 4.0 & $<2.0$ & 6.6 \\
\hline M08-16-00-I & W-220623 & .36 & 54 & $<.02$ & $<2.0$ & $<1.0$ & .19 & - & 65 & $<2.0$ & 4.6 & $<2.0$ & 7.9 \\
\hline M08-17-00-BL & W-220628 & .27 & 17 & $<.02$ & $<2.0$ & $<1.0$ & .13 & - & 83 & $<2.0$ & 2.3 & $<2.0$ & 3.3 \\
\hline M08-17-00-G & $\mathrm{W}-220625$ & .22 & 16 & $<.02$ & $<2.0$ & $<1.0$ & .08 & - & 40 & $<2.0$ & 2.0 & $<2.0$ & 2.5 \\
\hline M08-17-00-H & W-220626 & .26 & 16 & $<.02$ & $<2.0$ & $<1.0$ & .18 & - & 140 & $<2.0$ & 1.7 & $<2.0$ & 5.0 \\
\hline M08-17-00-I & W-220627 & .23 & 15 & $<.02$ & $<2.0$ & $<1.0$ & .10 & - & 64 & $<2.0$ & 1.1 & $<2.0$ & 2.9 \\
\hline M08-18-00-BL & W-220632 & .31 & 33 & .18 & $<2.0$ & $<1.0$ & .15 & - & 55 & $<2.0$ & 3.0 & $<2.0$ & 5.4 \\
\hline M08-18-00-G & $W-220629$ & .30 & 32 & $<.02$ & $<2.0$ & $<1.0$ & .14 & - & 62 & $<2.0$ & 4.0 & $<2.0$ & 5.0 \\
\hline M08-18-00-H & $W-220630$ & .33 & 39 & $<.02$ & $<2.0$ & $<1.0$ & .17 & - & 54 & $<2.0$ & 3.0 & $<2.0$ & 5.8 \\
\hline M08-18-00-I & $\mathrm{W}-220631$ & .34 & 32 & $<.02$ & $<2.0$ & $<1.0$ & .15 & - & 57 & $<2.0$ & 2.7 & $<2,0$ & 5.0 \\
\hline
\end{tabular}


[Values are accurate to two significant figures]

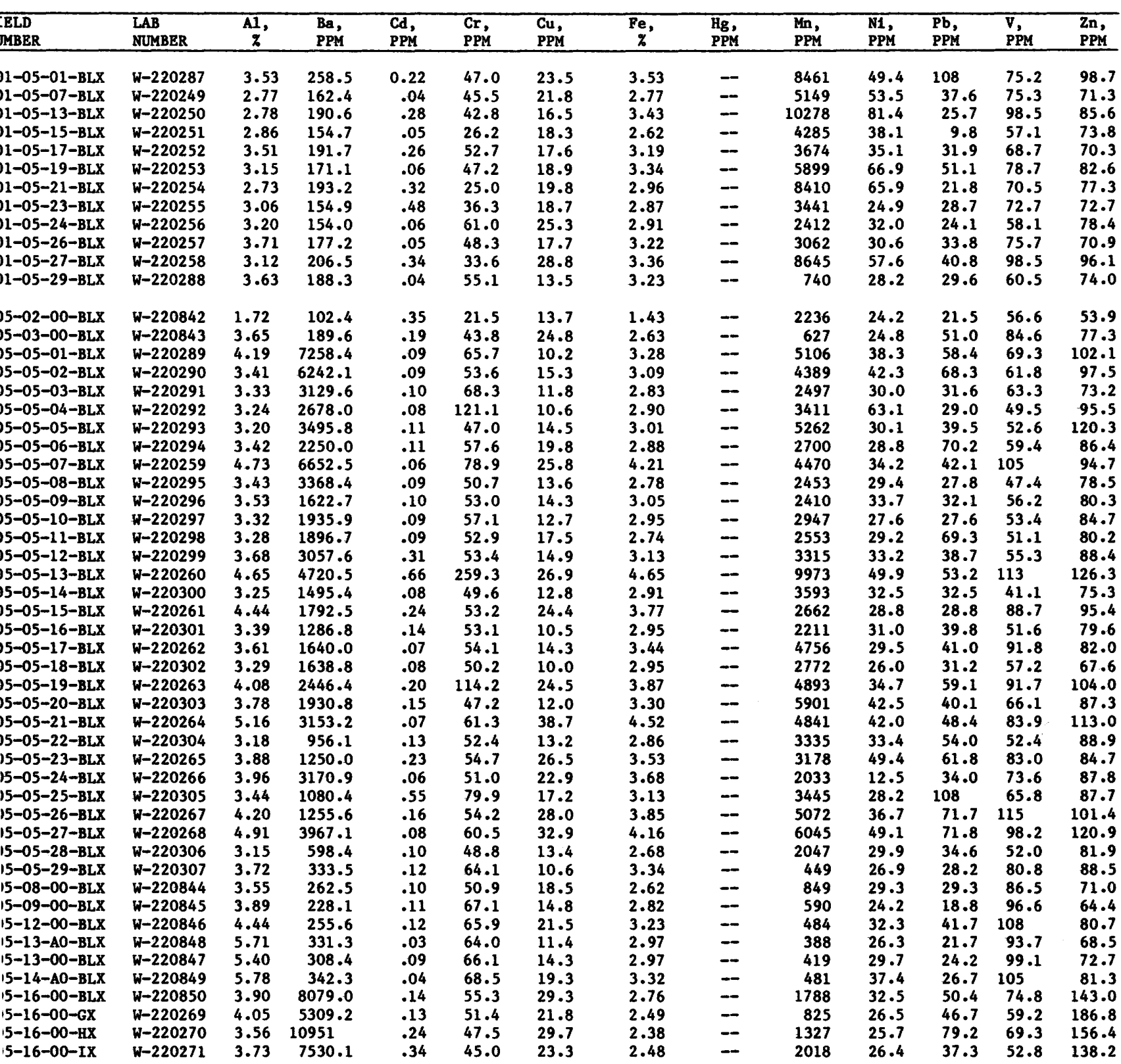




\begin{tabular}{|c|c|c|c|c|c|c|c|c|c|c|c|c|c|}
\hline $\begin{array}{l}\text { FIELD } \\
\text { NUMBER } \\
\end{array}$ & $\begin{array}{l}\text { LAB } \\
\text { NUMBER } \\
\end{array}$ & $\begin{array}{c}\mathrm{Al}, \\
\%\end{array}$ & $\begin{array}{l}\text { Ba, } \\
\text { PPM }\end{array}$ & $\begin{array}{l}\text { Cd, } \\
\text { PPM }\end{array}$ & $\begin{array}{l}\text { Cr, } \\
\text { PPM }\end{array}$ & $\begin{array}{l}\mathrm{Cu}, \\
\mathrm{PPM}\end{array}$ & $\begin{array}{c}\mathrm{Fe}, \\
\%\end{array}$ & $\begin{array}{l}\text { H, } \\
\text { PPM }\end{array}$ & $\begin{array}{l}\text { Mn, } \\
\text { PPM }\end{array}$ & $\begin{array}{l}\mathrm{NI}, \\
\mathrm{PPM}\end{array}$ & $\begin{array}{l}\mathrm{Pb}, \\
\mathrm{PPM}\end{array}$ & $\begin{array}{l}\text { V, } \\
\text { PPM }\end{array}$ & $\begin{array}{l}\text { Zn, } \\
\text { PPM }\end{array}$ \\
\hline M05-17-00-BLX & W-220851 & 3.16 & 632.6 & 0.15 & 38.0 & 31.6 & 2.32 & -- & 1413 & 27.4 & 35.8 & 59.0 & 69.6 \\
\hline M05-17-00-GX & $W-220272$ & 3.36 & 746.7 & .12 & 33.6 & 20.5 & 2.43 & - & 1456 & 24.3 & 24.3 & 44.8 & 78.4 \\
\hline MO5-17-00-HX & W-220273 & 4.69 & 993.8 & .28 & 44.2 & 33.1 & 3.04 & -- & 1546 & 35.9 & 52.5 & 49.7 & 104.9 \\
\hline M05-17-00-IX & W-220274 & 2.45 & 515.5 & .05 & 13.7 & 19.4 & 1.74 & - & 908 & 10.8 & 17.4 & 27.0 & 78.5 \\
\hline M05-18-00-BLX & W-220852 & 3.49 & 1719.6 & .35 & 42.7 & 31.0 & 2.33 & -- & 1241 & 29.1 & 40.7 & 67.9 & 87.2 \\
\hline M05-18-00-GX & W-220308 & 3.62 & 2100.4 & .11 & 44.8 & 9.1 & 2.24 & -- & 723 & 27.5 & 29.3 & 36.2 & 89.5 \\
\hline M05-18-00-HX & W-220309 & 3.15 & 2095.3 & .04 & 38.9 & 8.9 & 2.23 & -- & 1539 & 24.1 & 31.5 & 35.2 & 77.9 \\
\hline M05-18-00-IX & $\mathrm{W}-220310$ & 2.71 & 1642.8 & .75 & 41.7 & 9.6 & 1.79 & - & 563 & 22.9 & 15.6 & 15.6 & 68.8 \\
\hline M06-02-00-BLX & $\mathrm{W}-220853$ & 2.13 & 119.7 & $<.07$ & 23.3 & 28.6 & 1.63 & $\ldots$ & 1662 & 19.9 & 16.6 & 53.2 & 56.5 \\
\hline M06-03-00-BLX & W-220854 & 3.66 & 196.9 & .21 & 43.6 & 26.7 & 2.67 & -- & 647 & 33.8 & 43.6 & 78.8 & 74.6 \\
\hline M06-05-01-BLX & W-220894 & 3.89 & 3287.9 & .25 & 60.3 & 21.4 & 3.11 & -- & 2335 & 31.1 & 25.3 & 85.6 & 73.9 \\
\hline M06-05-02-BLX & W-220895 & 3.58 & 1512.5 & .28 & 58.5 & 20.7 & 3.21 & - & 4715 & 43.4 & 35.8 & 113 & 94.3 \\
\hline M06-05-04-BLX & W-220896 & 2.99 & 989.6 & .41 & 48.3 & 20.7 & 2.53 & -- & 3222 & 32.2 & 32.2 & 75.9 & 73.6 \\
\hline M06-05-06-BLX & W-220897 & 3.05 & 738.0 & .28 & 50.9 & 20.6 & 2.80 & -- & 4581 & 40.7 & 61.1 & 84.0 & 81.4 \\
\hline M06-05-10-BLX & W-220898 & 3.75 & 1154.4 & .13 & 67.1 & 23.7 & 3.35 & -- & 4539 & 45.4 & 49.3 & 118 & 84.9 \\
\hline M06-05-14-BLX & W-220899 & 3.30 & 858.3 & .19 & 52.8 & 22.0 & 3.30 & - & 8583 & 66.0 & 52.8 & 101 & 83.6 \\
\hline M06-05-16-BLX & $W-220900$ & 3.49 & 888.1 & .17 & 53.9 & 22.5 & 3.11 & -- & 3108 & 31.7 & 73.0 & 88.8 & 79.3 \\
\hline M06-05-18-BLX & W-220901 & 4.40 & 898.6 & .18 & 70.7 & 22.9 & 3.82 & - & 3441 & 53.5 & 51.6 & 126 & 101.3 \\
\hline M06-05-20-BLX & W-220902 & 2.41 & 901 & .36 & 57.7 & 22.7 & 2.95 & - & 11200 & 68.5 & 82.9 & 101 & 82.9 \\
\hline M06-05-22-BLX & W-220903 & 5.83 & 806.7 & .09 & 85.2 & 40.3 & 5.38 & - & 7171 & 76.2 & 71.7 & 157 & 138.9 \\
\hline M06-05-25-BLX & W-220904 & 2.77 & 836.7 & .23 & 55.4 & 16.5 & 2.95 & - & 2252 & 34.6 & 46.8 & 100 & 64.1 \\
\hline M06-05-28-BLX & W-220905 & 2.51 & 855.9 & .05 & 38.8 & 17.3 & 2.51 & - & 4337 & 59.3 & 38.8 & 73.0 & 57.1 \\
\hline M06-05-29-BLX & W-220906 & 3.08 & 537.4 & .06 & 64.4 & 21.0 & 3.22 & - & 280 & 32.2 & 36.4 & 102 & 64.4 \\
\hline M06-08-00-BLX & W-220855 & 4.00 & 311.2 & .13 & 54.8 & 22.2 & 2.96 & -- & 874 & 34.1 & 38.5 & 77.1 & 75.6 \\
\hline M06-09-00-BLX & W-220856 & 4.69 & 312.6 & .16 & 85.3 & 18.5 & 3.13 & - & 611 & 31.3 & 32.7 & 105 & 79.6 \\
\hline M06-12-00-BLX & W-220857 & 4.45 & 287.2 & .07 & 61.7 & 21.5 & 3.30 & -- & 560 & 33.0 & 30.2 & 96.2 & 83.3 \\
\hline M06-13-A0-BLX & W-220859 & 4.16 & 309.6 & $<.02$ & 58.7 & 10.7 & 2.56 & -- & 331 & 26.7 & 24.6 & 93.9 & 64.1 \\
\hline MO6-13-00-BLX & W-220858 & 5.06 & 296.8 & .04 & 66.0 & 14.3 & 2.86 & -- & 429 & 25.3 & 29.7 & 103 & 71.5 \\
\hline M06-14-A0-BLX & W-220860 & 5.25 & 366.2 & .03 & 76.9 & 18.3 & 3.30 & - & 513 & 39.1 & 30.5 & 110 & 86.7 \\
\hline M06-16-00-BLX & $W-220861$ & 3.29 & 7343.5 & .12 & 50.1 & 21.9 & 2.35 & - & 1722 & 36.0 & 48.5 & 67.3 & 144.1 \\
\hline M06-16-00-GX & W-220275 & 3.78 & 11636 & .04 & 49.8 & 24.0 & 2.75 & - & 1407 & 30.9 & 39.5 & 49.8 & 137.3 \\
\hline M06-16-00-HX & $W-220276$ & 3.99 & 6884.8 & .29 & 43.5 & 19.9 & 2.54 & - & 1667 & 23.6 & 39.9 & 47.1 & 253.6 \\
\hline M06-16-00-IX & W-220277 & 3.06 & 10286 & .13 & 38.2 & 26.8 & 2.29 & -- & 1682 & 24.9 & 30.6 & 40.2 & 147.2 \\
\hline M06-17-00-BLX & W-220862 & 3.39 & 716.6 & .08 & 41.5 & 20.7 & 2.26 & - & 943 & 35.8 & 47.1 & 64.1 & 81.1 \\
\hline M06-17-00-GX & W-220278 & 3.79 & 658.2 & .06 & 37.9 & 25.9 & 2.59 & - & 878 & 25.9 & 63.8 & 45.9 & 95.7 \\
\hline $\mathrm{M} 06-17-00-\mathrm{HX}$ & W-220279 & 3.51 & 613.8 & .22 & 30.7 & 21.5 & 2.41 & $m$ & 877 & 17.8 & 26.3 & 50.4 & 83.3 \\
\hline M06-17-00-IX & $W-220280$ & 3.78 & 432.0 & .04 & 37.8 & 21.6 & 2.70 & - & 702 & 27.0 & 30.6 & 46.8 & 93.6 \\
\hline M06-18-00-BLX & W-220863 & 2.86 & 1622.1 & .08 & 39.3 & 21.5 & 2.15 & - & 966 & 30.4 & 19.7 & 53.7 & 76.9 \\
\hline$M 06-18-00-G X$ & $\mathrm{~W}-220311$ & 3.13 & 1670.6 & .09 & 42.4 & 8.1 & 2.03 & 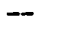 & 903 & 35.0 & 27.6 & 35.0 & 84.7 \\
\hline M06-18-00-HX & W-220312 & 2.99 & 1685.0 & .60 & 42.7 & 9.8 & 2.35 & - & 1152 & 23.5 & 23.5 & 38.4 & 70.4 \\
\hline M06-18-00-IX & W-220313 & 3.63 & 2540.7 & .25 & 47.8 & 7.6 & 2.47 & 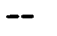 & 1287 & 34.6 & 33.0 & 36.3 & 85.8 \\
\hline M07-02-00-BLX & W-220864 & 1.32 & 255.0 & $<.06$ & 15.0 & 9.9 & 1.08 & -- & 2130 & 18.0 & 19.8 & 39.0 & 45.0 \\
\hline M07-03-00-BLX & W-220865 & 3.80 & 292.5 & .12 & 49.7 & 26.3 & 2.92 & 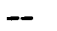 & 1243 & 38.0 & 65.8 & 87.7 & 84.8 \\
\hline M07-05-01-BLX & W-220866 & 3.34 & 7884.7 & .10 & 55.1 & 16.9 & 2.75 & -- & 5112 & 37.4 & 31.5 & 78.7 & 78.7 \\
\hline$M 07-05-01-G X$ & $W-220314$ & 3.60 & 9333.1 & .04 & 60.1 & 7.9 & 2.92 & -- & 4977 & 30.9 & 29.2 & 51.5 & 82.4 \\
\hline M07-05-01-HX & $W-220315$ & 4.23 & 8307.5 & .11 & 66.5 & 7.5 & 3.02 & . & 4436 & 38.3 & 28.2 & 56.5 & 84.7 \\
\hline M07-05-01-IX & $\mathrm{W}-220316$ & 2.34 & 10429 & .11 & 30.7 & 7.5 & 2.26 & - & 7250 & 22.6 & 41.8 & 36.2 & 75.3 \\
\hline M07-05-18-BLX & $W-220323$ & 3.49 & 796.6 & .28 & 48.1 & 14.8 & 2.99 & - & 3651 & 39.8 & 34.9 & 63.1 & 79.7 \\
\hline$M 07-05-18-G X$ & $\mathrm{~W}-220317$ & 3.65 & 1415.7 & .04 & 51.4 & 21.6 & 2.99 & - & 3485 & 34.9 & 56.4 & 58.1 & 83.0 \\
\hline M07-05-18-HX & W-220318 & 3.56 & 778.1 & .08 & 50.9 & 15.4 & 3.22 & -1 r & 3221 & 40.7 & 35.6 & 69.5 & 91.5 \\
\hline M07-05-18-IX & W-220319 & 3.48 & 1324.7 & .09 & 53.1 & 18.3 & 3.11 & -- & 4025 & 38.4 & 45.7 & 73.2 & 87.8 \\
\hline M07-05-28-BLX & $W-220324$ & 2.17 & 212.0 & $<.09$ & $<9.4$ & 13.7 & 1.74 & 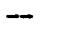 & 5653 & 32.5 & 10.8 & $<9.4$ & 56.5 \\
\hline M07-05-28-GX & W-220320 & 1.16 & 164.0 & $<.07$ & $<7.5$ & 13.0 & 1.34 & - & 5591 & 37.3 & 8.6 & $<7.5$ & 44.7 \\
\hline
\end{tabular}




\begin{tabular}{|c|c|c|c|c|c|c|c|c|c|c|c|c|c|}
\hline $\begin{array}{l}\text { FIELD } \\
\text { NUMBER } \\
\end{array}$ & $\begin{array}{l}\mathrm{LAB} \\
\text { NUMBER }\end{array}$ & $\begin{array}{c}\mathrm{A1}, \\
\%\end{array}$ & $\begin{array}{l}\mathrm{Ba}, \\
\mathrm{PPM}\end{array}$ & $\begin{array}{l}\text { Cd, } \\
\text { PPM }\end{array}$ & $\begin{array}{l}\text { Cr, } \\
\text { PPM }\end{array}$ & $\begin{array}{l}\mathrm{Cu}, \\
\mathrm{PPM}\end{array}$ & $\begin{array}{c}\mathrm{Fe}, \\
\%\end{array}$ & $\begin{array}{l}\mathrm{Hg}, \\
\mathrm{PPM}\end{array}$ & $\begin{array}{l}\mathrm{Mn}, \\
\mathrm{PPM}\end{array}$ & $\begin{array}{l}\text { Ni, } \\
\text { PPM }\end{array}$ & $\begin{array}{l}\mathrm{Pb}, \\
\mathrm{PPM}\end{array}$ & $\begin{array}{l}\text { V, } \\
\text { PPM }\end{array}$ & $\begin{array}{l}\mathrm{Zn}, \\
\mathrm{PPM}\end{array}$ \\
\hline M07-05-28-HX & $W-220321$ & 1.90 & 275.6 & 0.11 & $<9.0$ & 14.9 & 2.21 & - & 9489 & 67.8 & 13.1 & $<9.0$ & 54.2 \\
\hline M07-05-28-IX & $\mathrm{W}-220322$ & 1.24 & 152.4 & $<.06$ & 7.2 & 10.6 & 1.21 & - & 2502 & 19.8 & 15.5 & $<5.8$ & 28.8 \\
\hline M07-07-A0-BLX & W-220867 & 4.89 & 403.7 & .16 & 75.8 & 24.5 & 2.94 & - & 355 & 40.4 & 34.2 & 106 & 80.7 \\
\hline M07-08-00-BLX & $\mathrm{W}-220868$ & 3.94 & 333.2 & .08 & 56.0 & 18.2 & 2.73 & - & 863 & 34.8 & 36.3 & 77.2 & 77.2 \\
\hline M07-13-00-BLX & $W-220869$ & 5.46 & 349.7 & .07 & 67.8 & 13.1 & 3.06 & - & 437 & 29.5 & 24.0 & 95.1 & 83.1 \\
\hline M07-14-A0-BLX & $W-220870$ & 6.49 & 408.7 & .05 & 81.7 & 20.4 & 3.85 & - & 565 & 45.7 & 38.5 & 132 & 99.8 \\
\hline M07-15-00-BLX & $W-220871$ & .64 & 56.3 & $<.08$ & 11.3 & 6.8 & .49 & - & 38 & $<7.5$ & 3.8 & 15.0 & 18.8 \\
\hline M07-16-00-BLX & $W-220872$ & 3.15 & 7581.9 & .05 & 43.6 & 23.3 & 2.18 & - & 969 & 29.1 & 38.8 & 50.9 & 123.5 \\
\hline M07-16-00-GX & $W-220281$ & 3.67 & 13636 & $<.05$ & 39.1 & 19.3 & 2.37 & -- & 1662 & 23.0 & 41.5 & 39.1 & 151.5 \\
\hline M07-16-00-HX & $W-220282$ & 3.11 & 6154.2 & .08 & 18.8 & 20.3 & 2.06 & - & 638 & 7.1 & 29.6 & 33.0 & 127.6 \\
\hline$M 07-16-00-I X$ & W-220283 & 3.47 & 9485.0 & .05 & 81.7 & 20.1 & 2.18 & -- & 495 & 17.1 & 47.1 & 21.8 & 247.7 \\
\hline $\mathrm{M} 07-17-00-\mathrm{BLX}$ & W-220873 & 4.13 & 432.3 & .16 & 54.5 & 37.6 & 2.82 & - & 526 & $41 \cdot 3$ & 54.5 & 77.1 & 95.9 \\
\hline$M 07-17-00-G X$ & W-220284 & 3.32 & 793.4 & .12 & 18.9 & 20.4 & 2.23 & -- & 869 & 7.2 & 34.4 & 23.8 & 102.0 \\
\hline M07-17-00-HX & $W-220285$ & 4.24 & 476.7 & .23 & 42.4 & 21.2 & 3.00 & - & 865 & 33.5 & 53.0 & 67.1 & 107.7 \\
\hline M07-17-00-IX & W-220286 & 4.62 & 421.9 & .26 & 48.2 & 32.1 & 3.01 & & 382 & 38.2 & 54.2 & $70 \cdot 3$ & 124.6 \\
\hline M08-02-00-BLX & $W-220874$ & 1.21 & $137 \cdot 3$ & .15 & 11.0 & 16.5 & .88 & - & 1319 & 13.7 & 20.1 & 27.5 & 41.2 \\
\hline M08-03-00-BLX & $W-220875$ & 3.80 & 230.9 & .10 & 46.2 & 24.4 & 2.72 & - & 815 & 32.6 & 48.9 & 86.9 & 76.1 \\
\hline M08-05-01-BLX & $W-220907$ & 3.54 & 2623.8 & .07 & 66.3 & 19.2 & 3.10 & - & 2064 & 42.7 & 33.9 & 91.4 & 73.7 \\
\hline M08-05-02-BLX & W-220908 & 3.67 & 1219.3 & .15 & 59.6 & 25.2 & 3.44 & - & 5271 & 43.5 & 50.4 & 91.7 & 96.3 \\
\hline M08-05-04-BLX & $W-220909$ & 2.92 & 608.2 & .13 & 51.1 & 20.7 & 3.16 & - & 6569 & 41.4 & 58.4 & 90.0 & 90.0 \\
\hline M08-05-06-BLX & $W-220910$ & 1.72 & 396.1 & .26 & 43.6 & 16.8 & 1.96 & - & 5545 & 35.6 & 31.7 & 59.4 & 59.4 \\
\hline M08-05-10-BLX & $\mathrm{W}-220911$ & 3.32 & 810.4 & .11 & 53.4 & 22.1 & 2.76 & - & 2763 & 35.0 & 29.5 & 79.2 & 73.7 \\
\hline M08-05-14-BLX & W-220912 & 2.15 & 278.8 & .13 & 39.0 & 19.8 & 2.37 & - & 6971 & 47.4 & 39.0 & 66.9 & 69.7 \\
\hline M08-05-16-BLX & $\mathrm{W}-220913$ & 2.30 & 287.8 & .11 & 40.6 & 17.9 & 2.44 & - & 4062 & 23.7 & 50.8 & 74.5 & 67.7 \\
\hline M08-05-18-BLX & W-220914 & 3.28 & 698.7 & .20 & 54.6 & 19.7 & 3.06 & - & 6332 & 45.9 & 41.5 & 93.9 & 83.0 \\
\hline M08-05-20-BLX & W-220915 & 3.87 & 1314.9 & .37 & 65.2 & 24.5 & 3.26 & - & 3466 & 53.0 & 40.8 & 91.7 & 87.7 \\
\hline M08-05-22-BLX & W-220916 & 2.78 & 446.6 & .57 & 54.2 & 21.7 & 3.03 & - & 8614 & 57.4 & 47.9 & 95.7 & 86.1 \\
\hline M08-05-25-BLX & $W-220917$ & 2.81 & 409.1 & .46 & 46.0 & 23.0 & 3.07 & - & 3835 & 25.6 & 58.8 & 89.5 & 76.7 \\
\hline M08-05-28-BLX & $W-220918$ & 1.93 & 197.9 & .42 & 37.4 & 24.6 & 2.30 & - & 9091 & 53.5 & 48.1 & 69.5 & 80.2 \\
\hline M08-05-29-BLX & W-220919 & 3.80 & 681.0 & .13 & 64.9 & 19.0 & 3.64 & - & 475 & 26.9 & 26.9 & 98.2 & 76.0 \\
\hline M08-08-00-BLX & W-220876 & 4.78 & 337.6 & .04 & 77.4 & 22.5 & 3.52 & - & 746 & 33.8 & 40.8 & 94.2 & 78.8 \\
\hline M08-09-00-BLX & W-220877 & 4.78 & 313.7 & .10 & 79.2 & 19.4 & 3.29 & - & 657 & 32.9 & 32.9 & 98.6 & 76.2 \\
\hline M08-12-00-BLX & $\mathrm{W}-220878$ & 2.90 & 846.3 & .14 & 39.3 & 18.6 & 1.97 & - & 579 & 26.9 & 31.0 & 62.1 & 72.4 \\
\hline M08-13-A0-BLX & $W-220880$ & 5.32 & 325.9 & .14 & 64.1 & 13.0 & 2.82 & - & 445 & 21.7 & 30.4 & 91.3 & 66.3 \\
\hline M08-13-00-BLX & W-220879 & 5.73 & 348.2 & .02 & 67.6 & 17.4 & 3.28 & - & 451 & 35.8 & 20.5 & 113 & 81.9 \\
\hline M08-14-AO-BLX & $W-220881$ & 5.34 & 335.1 & .04 & 60.7 & 10.5 & 2.83 & - & 356 & 23.0 & 26.2 & 88.0 & 60.7 \\
\hline M08-16-00-BLX & $W-220885$ & 3.85 & 5473.8 & .33 & 61.2 & 31.5 & 2.97 & - & 1102 & 33.2 & 59.5 & 87.4 & 141.7 \\
\hline M08-16-00-GX & $W-220882$ & 3.62 & 2737.4 & .12 & 53.4 & 25.8 & 2.93 & - & 1067 & 31.0 & 46.5 & 75.8 & 108.5 \\
\hline MO8-16-00-HX & $W-220883$ & 4.15 & 12692 & .28 & 69.8 & 30.2 & 3.02 & - & 1641 & 37.7 & 58.5 & 88.6 & 226.3 \\
\hline M08-16-00-IX & $W-220884$ & 4.07 & 1959.0 & .35 & 61.0 & 33.3 & 3.14 & $\rightarrow$ & 591 & 38.8 & 64.7 & 96.1 & 138.6 \\
\hline M08-17-00-BLX & $W-220889$ & 1.73 & 126.1 & .28 & 23.4 & 24.8 & 1.45 & - & 794 & 9.3 & 28.0 & 32.7 & 60.7 \\
\hline M08-17-00-GX & $W-220886$ & 2.11 & 235.9 & .31 & 32.7 & 24.7 & 1.74 & - & 871 & 18.1 & 34.8 & 50.8 & 65.3 \\
\hline M08-17-00-HX & $W-220887$ & 1.45 & 82.9 & .12 & 24.9 & 19.1 & 1.04 & - & 394 & 12.4 & 11.2 & 20.7 & 53.9 \\
\hline M08-17-00-IX & $W=220888$ & 1.25 & 90.8 & .23 & 14.2 & 18.2 & .97 & - & 517 & $<11.4$ & 18.7 & 17.0 & 47.1 \\
\hline M08-18-00-BLX & W-220893 & 3.45 & 1012.6 & .20 & 52.9 & 27.6 & 2.30 & - & 782 & 32.2 & 36.8 & 73.6 & 87.5 \\
\hline$M 08-18-00-G X$ & $\mathrm{~W}-220890$ & 7.56 & 2819.1 & 1.38 & 82.5 & 103.1 & 5.16 & - & 2682 & 28.2 & 151 & 96.3 & 398.8 \\
\hline M08-18-00-HX & W-220891 & 3.02 & 888.4 & .12 & 40.9 & 24.9 & 1.95 & - & 320 & 30.2 & 30.2 & 58.6 & 76.4 \\
\hline M08-18-00-IX & W-220892 & 3.73 & 275.5 & .15 & 56.7 & 22.7 & 2.59 & - & 746 & 30.8 & 21.1 & 87.5 & 74.6 \\
\hline
\end{tabular}


[S0, undifferentiated; S1, >1,000 $\mu \mathrm{m} ; \mathrm{S} 2,1,000-500 \mu \mathrm{m}$; S3. 500-210 $\mu \mathrm{m} ; \mathrm{S4}, 210-105 \mu \mathrm{m}$;

$\mathrm{S} 5,105-60 \mu \mathrm{m} ; \mathrm{S} 6,60-30 \mu \mathrm{m} ; \mathrm{S} 7,30-10 \mu \mathrm{m} ; \mathrm{S} 8,10-1 \mu \mathrm{m} ; \mathrm{S} 9<1 \mu \mathrm{m}$ ]

\begin{tabular}{|c|c|c|c|c|c|c|c|c|c|c|c|c|c|}
\hline $\begin{array}{l}\text { FIELD } \\
\text { NUMBER } \\
\end{array}$ & $\begin{array}{l}\text { LAB } \\
\text { NUMBER } \\
\end{array}$ & $\begin{array}{c}\text { A1, } \\
\%\end{array}$ & $\begin{array}{l}\mathrm{Ba}, \\
\mathrm{PPM} \\
\end{array}$ & $\begin{array}{l}\text { Cd, } \\
\text { PPM } \\
\end{array}$ & $\begin{array}{l}\mathbf{C r}, \\
\text { PPM } \\
\end{array}$ & $\begin{array}{l}\text { Cu, } \\
\text { PPM }\end{array}$ & $\begin{array}{c}\mathrm{Fe}, \\
\%\end{array}$ & $\begin{array}{l}\mathrm{Hg}, \\
\mathrm{PPM}\end{array}$ & $\begin{array}{l}\text { Mn, } \\
\text { PPM }\end{array}$ & $\begin{array}{l}\mathbf{N 1}, \\
\text { PPM }\end{array}$ & $\begin{array}{l}\mathrm{Pb}, \\
\mathrm{PPM}\end{array}$ & $\begin{array}{l}\text { V, } \\
\text { PPM }\end{array}$ & $\begin{array}{l}\mathrm{Zn}, \\
\mathrm{PPM}\end{array}$ \\
\hline $\begin{array}{l}\mathrm{M} 4-02-00-\mathrm{S} 0 \\
\mathrm{M} 04-02-00-\mathrm{S} 1 \\
\mathrm{M} 4-02-00-\mathrm{S} 2 \\
\mathrm{M} 04-02-00-\mathrm{S} 3 \\
\mathrm{M} 4-02-00-\mathrm{S} 4 \\
\mathrm{M} 04-02-00-\mathrm{S} 5 \\
\mathrm{M} 4-02-00-\mathrm{S} 6 \\
\mathrm{M} 4-02-00-\mathrm{S} 7 \\
\mathrm{M} 4-02-00-\mathrm{S} 8 \\
\mathrm{M} 4-02-00-\mathrm{S} 9\end{array}$ & $\begin{array}{l}W-221282 \\
W-219904 \\
W-219905 \\
W-219906 \\
W-219907 \\
W-219908 \\
W-219893 \\
W-219894 \\
W-219895 \\
W-219896\end{array}$ & $\begin{array}{r}0.27 \\
.32 \\
.16 \\
.25 \\
1.20 \\
2.00 \\
1.90 \\
3.00 \\
3.00 \\
.18\end{array}$ & $\begin{array}{r}83 \\
51 \\
32 \\
51 \\
150 \\
260 \\
280 \\
240 \\
480 \\
34\end{array}$ & $\begin{array}{r}<0.02 \\
<.02 \\
<.02 \\
<.02 \\
.03 \\
.26 \\
8.20 \\
1.60 \\
3.70 \\
.19\end{array}$ & $\begin{array}{r}<2.0 \\
3.3 \\
<2.0 \\
10.0 \\
24.0 \\
49.0 \\
38.0 \\
36.0 \\
98.0 \\
3.3\end{array}$ & $\begin{array}{r}<1.0 \\
<1.0 \\
<1.0 \\
<1.0 \\
<1.0 \\
4.6 \\
13.0 \\
45.0 \\
240.0 \\
5.0\end{array}$ & $\begin{array}{r}0.11 \\
.27 \\
.09 \\
.07 \\
1.90 \\
2.30 \\
1.80 \\
2.90 \\
3.00 \\
.16\end{array}$ & $\begin{array}{c}0.01 \\
-- \\
- \\
-- \\
- \\
-- \\
- \\
-- \\
-- \\
--\end{array}$ & $\begin{array}{r}110 \\
300 \\
84 \\
26 \\
1400 \\
3900 \\
11000 \\
8400 \\
7500 \\
290\end{array}$ & $\begin{array}{r}<2.0 \\
4.9 \\
<2.0 \\
<2.0 \\
8.3 \\
32.0 \\
78.0 \\
110.0 \\
320.0 \\
9.4\end{array}$ & $\begin{array}{r}2.7 \\
4.0 \\
1.9 \\
2.7 \\
13.0 \\
11.0 \\
28.0 \\
75.0 \\
110 \\
3.1\end{array}$ & $\begin{array}{r}<2.0 \\
10.0 \\
3.1 \\
<2.0 \\
16.0 \\
59.0 \\
51.0 \\
85.0 \\
70.0 \\
7.5\end{array}$ & $\begin{array}{r}5.0 \\
4.6 \\
2.1 \\
<2.0 \\
23.0 \\
51.0 \\
98.0 \\
150.0 \\
290.0 \\
17.0\end{array}$ \\
\hline $\begin{array}{l}\mathrm{M} 4-05-02-\mathrm{S} 0 \\
\mathrm{M} 04-05-02-\mathrm{S} 1 \\
\mathrm{M} 4-05-02-\mathrm{S} 2 \\
\mathrm{M} 4-05-02-\mathrm{S} 3 \\
\mathrm{M} 4-05-02-\mathrm{S} 4 \\
\mathrm{M} 4-05-02-\mathrm{S} 5 \\
\mathrm{M} 4-05-02-\mathrm{S} 6 \\
\mathrm{M} 4-05-02-\mathrm{S} 7 \\
\mathrm{M} 4-05-02-\mathrm{S} 8 \\
\mathrm{M} 4-05-02-\mathrm{S} 9\end{array}$ & $\begin{array}{l}W-221272 \\
W-221273 \\
W-221274 \\
W-221275 \\
W-221276 \\
W-221277 \\
W-221278 \\
W-221279 \\
W-221280 \\
W-221281\end{array}$ & $\begin{array}{r}.24 \\
.19 \\
.11 \\
.23 \\
1.30 \\
2.20 \\
3.50 \\
3.70 \\
3.60 \\
.63\end{array}$ & $\begin{array}{r}87 \\
74 \\
16 \\
43 \\
279 \\
1060 \\
12000 \\
4500 \\
3500 \\
359\end{array}$ & $\begin{array}{l}<.02 \\
<.02 \\
<.02 \\
<.02 \\
<.02 \\
.05 \\
.29 \\
.40 \\
.46 \\
.09\end{array}$ & $\begin{array}{r}3.0 \\
<2.0 \\
<2.0 \\
<2.2 \\
24.0 \\
37.0 \\
55.0 \\
58.0 \\
69.0 \\
9.0\end{array}$ & $\begin{array}{r}<1.0 \\
<1.0 \\
<1.0 \\
<1.0 \\
1.7 \\
3.6 \\
20.0 \\
28.0 \\
130.0 \\
14.8\end{array}$ & $\begin{array}{r}.38 \\
.72 \\
.35 \\
.28 \\
1.10 \\
1.80 \\
3.20 \\
3.40 \\
3.40 \\
.54\end{array}$ & $\begin{array}{l}.01 \\
.01 \\
.01 \\
.01 \\
.01 \\
.01 \\
.05 \\
.08 \\
.13\end{array}$ & $\begin{array}{r}250 \\
310 \\
190 \\
180 \\
650 \\
1700 \\
5000 \\
4700 \\
4300 \\
448\end{array}$ & $\begin{array}{r}<2.0 \\
<2.0 \\
<2.0 \\
<2.0 \\
<2.0 \\
8.5 \\
34.0 \\
46.0 \\
46.0 \\
9.0\end{array}$ & $\begin{array}{r}5.5 \\
4.0 \\
4.0 \\
5.9 \\
14.0 \\
27.0 \\
66.0 \\
99.0 \\
120 \\
17.9\end{array}$ & $\begin{array}{r}6.0 \\
22.0 \\
5.0 \\
2.2 \\
30.0 \\
64.0 \\
100 \\
110 \\
28.0 \\
9.0\end{array}$ & $\begin{array}{r}6.6 \\
6.6 \\
4.6 \\
7.3 \\
20.0 \\
34.0 \\
100.0 \\
120.0 \\
320.0 \\
53.8\end{array}$ \\
\hline $\begin{array}{l}\text { M04-16-00-S1 } \\
\text { M04-16-00-S2 } \\
\text { M04-16-00-S3 } \\
\text { M04-16-00-S4 } \\
\text { M04-16-00-S5 } \\
\text { M04-16-00-S6 } \\
\text { M04-16-00-S7 } \\
\text { M04-16-00-S8 } \\
\text { M04-16-00-S9 }\end{array}$ & $\begin{array}{l}W-219897 \\
W-219898 \\
W-219899 \\
W-219900 \\
W-219909 \\
W-219910 \\
W-219911 \\
W-219912 \\
W-219913\end{array}$ & $\begin{array}{l}.52 \\
.16 \\
.26 \\
1.00 \\
2.40 \\
3.40 \\
3.90 \\
4.40 \\
1.60\end{array}$ & $\begin{array}{r}72 \\
27 \\
44 \\
280 \\
4150 \\
3730 \\
1900 \\
1200 \\
250\end{array}$ & $\begin{array}{r}<.02 \\
<.02 \\
<.02 \\
<.02 \\
.61 \\
.84 \\
2.90 \\
2.60 \\
.29\end{array}$ & $\begin{array}{r}3.1 \\
<2.0 \\
2.2 \\
33.0 \\
34.0 \\
43.0 \\
57.0 \\
62.0 \\
25.0\end{array}$ & $\begin{array}{r}<1.0 \\
<1.0 \\
<1.0 \\
2.0 \\
5.3 \\
22.0 \\
50.0 \\
56.0 \\
11.0\end{array}$ & $\begin{array}{r}.24 \\
.06 \\
.14 \\
2.20 \\
1.60 \\
2.50 \\
3.00 \\
3.40 \\
1.30\end{array}$ & $\begin{array}{l}-- \\
-- \\
-- \\
-- \\
- \\
- \\
-\end{array}$ & $\begin{array}{r}51 \\
<10 \\
83 \\
1500 \\
400 \\
900 \\
1100 \\
1300 \\
500\end{array}$ & $\begin{array}{r}2.9 \\
<2.0 \\
<2.0 \\
9.3 \\
17.0 \\
27.0 \\
79.0 \\
78.0 \\
27.0\end{array}$ & $\begin{array}{c}3.7 \\
2.0 \\
2.7 \\
23.0 \\
16.0 \\
64.0 \\
120 \\
120 \\
20.0\end{array}$ & $\begin{array}{r}5.4 \\
<2.0 \\
2.9 \\
22.0 \\
34.0 \\
51.0 \\
49.0 \\
63.0 \\
34.0\end{array}$ & $\begin{array}{r}5.4 \\
2.1 \\
4.2 \\
32.0 \\
67.0 \\
120.0 \\
250.0 \\
260.0 \\
80.0\end{array}$ \\
\hline
\end{tabular}







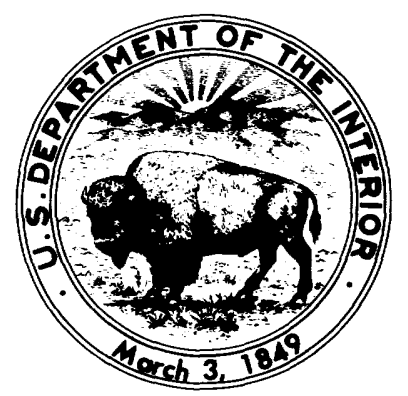

